\title{
Magmatic Ore Deposits in Layered Intrusions-Descriptive Model for Reef-Type PGE and Contact-Type Cu-Ni-PGE Deposits
}

Open-File Report 2012-1010 


\section{Magmatic Ore Deposits in Layered Intrusions-Descriptive Model for Reef-Type PGE and Contact-Type Cu-Ni-PGE Deposits}

By Michael L. Zientek

Open-File Report 2012-1010 


\section{U.S. Department of the Interior \\ KEN SALAZAR, Secretary}

\section{U.S. Geological Survey \\ Marcia K. McNutt, Director}

U.S. Geological Survey, Reston, Virginia 2012

For product and ordering information:

World Wide Web: http://www.usgs.gov/pubprod

Telephone: 1-888-ASK-USGS

For more information on the USGS-the Federal source for science about the Earth, its natural and living resources, natural hazards, and the environment:

World Wide Web: http://www.usgs.gov

Telephone: 1-888-ASK-USGS

Any use of trade, product, or firm names is for descriptive purposes only and does not imply endorsement by the U.S. Government.

Although this report is in the public domain, permission must be secured from the individual copyright owners to reproduce any copyrighted material contained within this report. 


\section{Contents}

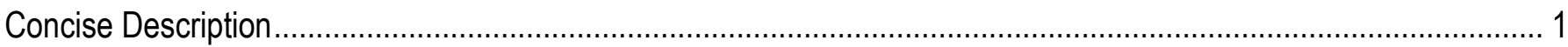

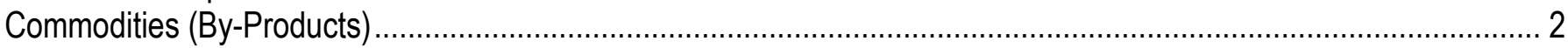

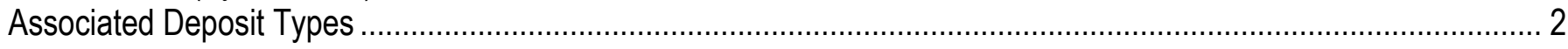

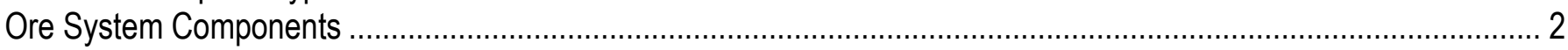

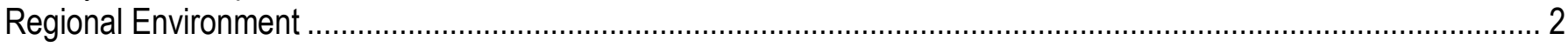

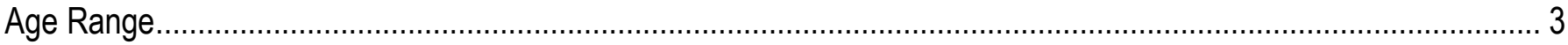

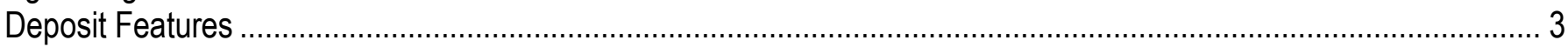

Reef-Type PGE

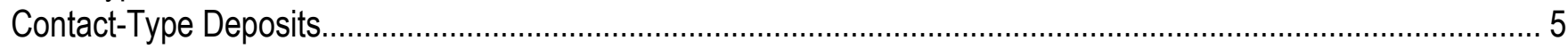

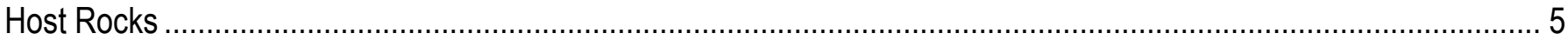

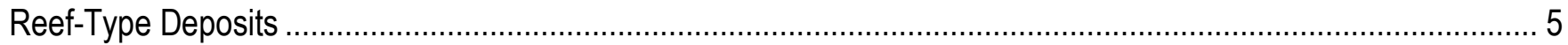

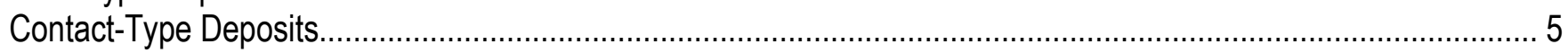

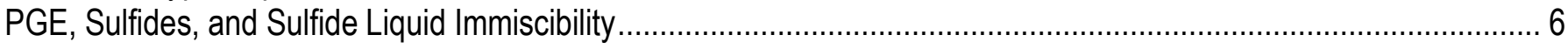

Processes That Determine Composition of Ores.........................................................................................

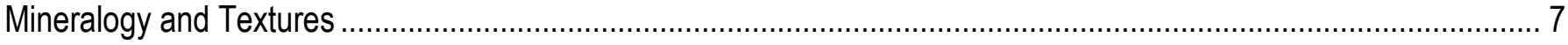

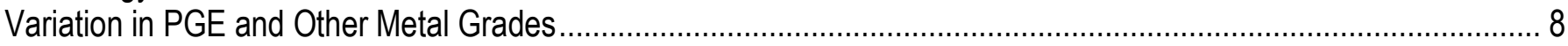

Reef-Type PGE-Relation of Thickness of Layer and Grade .................................................................... 8

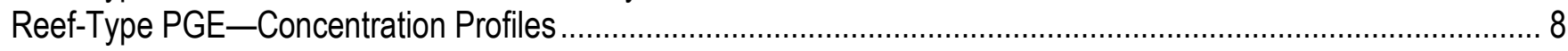

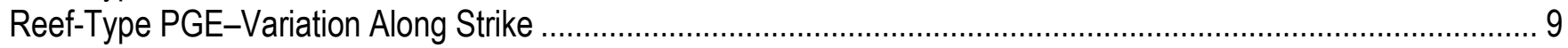

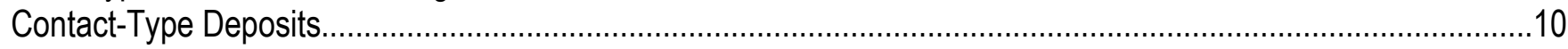

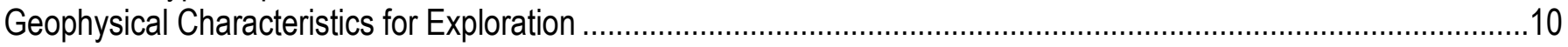

Geochemical Characteristics for Exploration ……....................................................................................

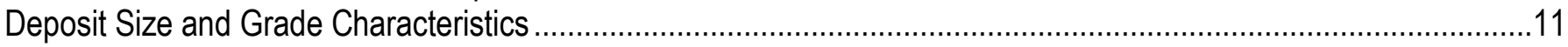

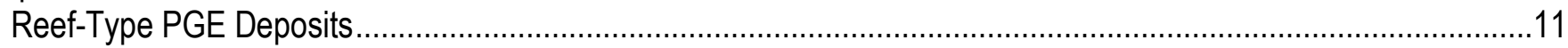

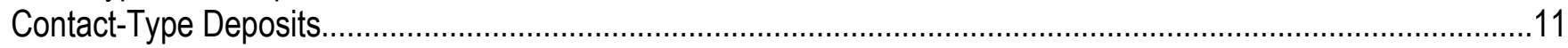

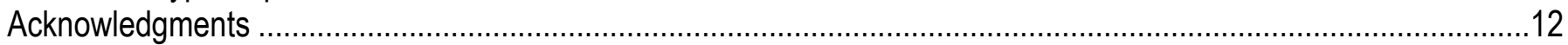

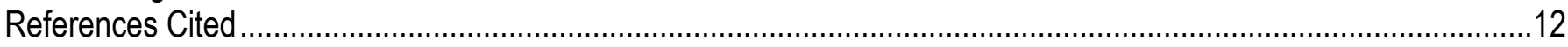

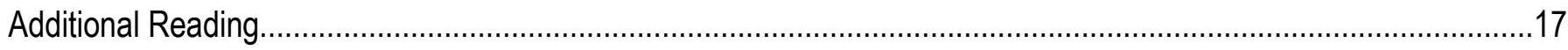

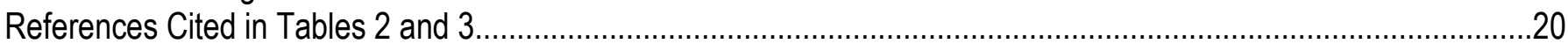

\section{Figures}

Figure 1. Histogram of the major world platinum-group elements (PGE) deposit resources. Reef-type deposits and contact-type deposits are shown in red and green, respectively. Data from Green and Peck (2005).......................... 23 Figure 2. Map showing the location of intrusions hosting reef-type platinum-group elements (PGE) and contact-type Cu-Ni-PGE deposits .....

Figure 3. Chart showing the occurrence of large igneous provinces and superplume events with time. The upper curve shows a time series of superplume events versus time derived from adding Gaussians defined by ages and age errors of individual superplume proxies; height of peak is related to events with high-precision ages (Abbot and Isley, 2002). The lower bar graph shows the starting time of pulses of well-established and probable plume-head maficmagmatic events (Ernst and others, 2005). Events that have layered igneous intrusions with reef-type platinum-group elements (PGE) and contact-type Cu-Ni-PGE deposits are labeled 
Figure 4. Columns that show the position of platinum-group elements reefs in the igneous stratigraphy of the Penikat, Munni Munni, Great Dyke, Stillwater, and Bushveld layered intrusions....

Figure 5. Stratigraphic variation of Sr isotope ratios in the Rustenburg Layered Series of the Bushveld Complex. Modified from (Kruger, 2005)

Figure 6. Stratigraphic variations in whole-rock Al, V, Fe, Cu, Au, Pd, and Pt contents in bore hole PA1 through the Precious Metals zone, Rincón del Tigre Complex, Bolivia. Modified from Prendergast (2000).

Figure 7. Section through two adjacent potholes illustrating the irregularity of the Merensky Reef, Bushveld Complex. Modified from Farquhar (1986)

Figure 8. Schematic representation of a fractionating, platinum-group elements (PGE) enriched immiscible sulfide liquid droplet. Major partitioning behavior at each stage is emphasized by bold text. (A) Immiscible sulfide liquid. (B) Crystallization of monosulfide solid solution (mss). Os, Ir, Ru, and Rh partition into the mss phase. (C) Crystallization of intermediate solid solution (iss) from residual sulfide liquid. Partitioning of Pt, $\mathrm{Pd}$, and $\mathrm{Au}$ into semimetal-rich melt. Some Pd partitions into mss. (D) Recrystallization of mss to pyrrhotite and pentlandite. Rh and Pd are in solid solution in pentlandite. Crystallization of discrete platinum minerals from iss and from the residual semimetal liquid. Modified from Holwell and McDonald (2010). PGM, platinum-group minerals

Figure 9. Variation in vertical value distribution for differing thicknesses of Merensky Reef, Amandelbult section of Rustenburg Platinum Mines. Modified from Viljoen and others (1986)

Figure 10. Bivariate plots of the combined grade of platinum, palladium, rhodium, and gold (4E) versus drill hole intercept for the UG2 chromitite and Merensky Reef, Bushveld Complex, the J-M Reef, Stillwater Complex, and the Ferguson Reef, Munni Munni Intrusion. Data are derived from company annual reports and presentations. PGE, platinum-group elements.

Figure 11. Profile through the J-M Reef, DDH701, 3800W stope, Stillwater Mine (Zientek and others, 1990)........ 33 Figure 12. Vertical variation of elements through the Main Sulphide Zone in the Darwendale Subchamber of the Great Dyke, modified from Naldrett and Wilson (1990)

Figure 13. Value contour map of the Merensky Reef, Rustenburg section of the Rustenburg Platinum Mines. Modified from Viljoen and Hieber (1986). PGE, platinum-group elements.

Figure 14. Map showing the outcrop trace of the Merensky Reef and its average platinum grade on mining properties in the Bushveld Complex. Data are derived from company annual reports and presentations and are current as of 2006.

Figure 15. Map showing the outcrop trace of the UG2 chromitite and its average platinum grade on mining properties in the Bushveld Complex. Data are derived from company annual reports and presentations and are

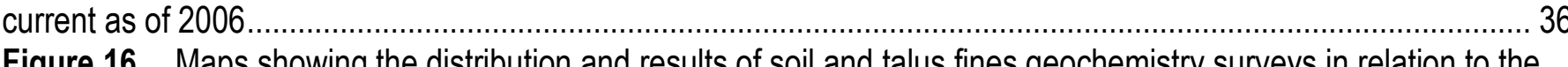
Figure 16. Maps showing the distribution and results of soil and talus fines geochemistry surveys in relation to the geology of the Stillwater Complex. (A) Location of talus and soil samples on map showing series level subdivisions of the Stillwater Complex. (B) Surface of log palladium values generated from sample data shown relative to the Stillwater Complex and unconsolidated deposits (Zientek and others, 2005).....

Figure 17. Bivariate plots of the average grade of palladium, rhodium, and gold versus average platinum grade for mines and mineral properties on the Stillwater, Stella, and Bushveld layered igneous intrusions. Data are derived from company annual reports and presentations and are current as of 2009.

Figure 18. Bivariate plot of the average platinum-group elements (PGE) grade versus mineralized layer thickness for PGE reef-type deposits

Figure 19. Histograms, box plots, and normal quantile plots illustrating distribution of tonnage of rock in contact-type deposits.

Figure 20. Histograms, box plots, and normal quantile plots illustrating distribution of copper, nickel, platinum, palladium, and gold in contact-type deposits

Figure 21. Box plots, comparison circles, and normal quantile plots comparing distribution of tonnage, copper grade, and nickel grade between deposits associated with the Bushveld, Keewenawan, and Baltica large igneous province (LIP) events.... 
Figure 22. Box plots, comparison circles, and normal quantile plots comparing distribution of palladium (Pd), platinum (Pt), and gold grade between deposits associated with the Bushveld, Keewenawan, and Baltica large igneous province (LIP) events

Figure 23. Ternary plot showing the proportion of copper, platinum, and palladium in contact-type deposits. LIP, large igneous province.

\section{Tables}

Table 1. The platinum group elements, their atomic numbers, chemical symbols, and value 44

Table 2. Tonnage and grade characteristics of reserves and resources associated with reef-type platinum-group elements deposits. Past production is not included. Large igneous province (LIP) names and ratings from Ernst and Buchan (2001)

Table 3. Tonnage and grade characteristics of contact-type copper-nickel platinum-group elements deposits. Values represent the total of resources and past production. Large igneous province (LIP) names and ratings from Ernst and Buchan (2001) 46

Table 4. Ages of intrusions that host reef-type platinum-group elements and contact-type Cu-Ni-PGE deposits 47

Table 5. Examples of cut-off criteria used to define contact-type Cu-Ni-platinum-group elements deposits

Table 6. Summary statistics of contact-type Cu-Ni-platinum-group elements deposits reported in table 2 


\title{
Magmatic Ore Deposits in Layered Intrusions- Descriptive Model of Reef-Type PGE and Contact-Type Cu-Ni-PGE Deposits
}

\author{
By Michael L. Zientek
}

\section{Concise Description}

Layered, ultramafic to mafic intrusions are uncommon in the geologic record, but host magmatic ore deposits containing most of the world's economic concentrations of platinum-group elements (PGE) (figs. 1 and 2). These deposits are mined primarily for their platinum, palladium, and rhodium contents (table 1). Magmatic ore deposits are derived from accumulations of crystals of metallic oxides, or immiscible sulfide, or oxide liquids that formed during the cooling and crystallization of magma, typically with mafic to ultramafic compositions.

"PGE reefs" are stratabound PGE-enriched lode mineralization in mafic to ultramafic layered intrusions. The term "reef" is derived from Australian and South African literature for this style of mineralization and used to refer to (1) the rock layer that is mineralized and has distinctive texture or mineralogy (Naldrett, 2004), or (2) the PGE-enriched sulfide mineralization that occurs within the rock layer. For example, Viljoen (1999) broadly defined the Merensky Reef as "a mineralized zone within or closely associated with an unconformity surface in the ultramafic cumulate at the base of the Merensky Cyclic Unit." In this report, we will use the term PGE reef to refer to the PGE-enriched mineralization, not the host rock layer. Within a layered igneous intrusion, reef-type mineralization is laterally persistent along strike, extending for the length of the intrusion, typically tens to hundreds of kilometers. However, the mineralized interval is thin, generally centimeters to meters thick, relative to the stratigraphic thickness of layers in an intrusion that vary from hundreds to thousands of meters.

PGE-enriched sulfide mineralization is also found near the contacts or margins of layered mafic to ultramafic intrusions (Iljina and Lee, 2005). This contact-type mineralization consists of disseminated to massive concentrations of iron-copper-nickel-PGE-enriched sulfide mineral concentrations in zones that can be tens to hundreds of meters thick. The modes and textures of the igneous rocks hosting the mineralization vary irregularly on the scale of centimeters to meters; autoliths and xenoliths are common. Mineralization occurs in the igneous intrusion and in the surrounding country rocks. Mineralization can be preferentially localized along contact with country rocks that are enriched in sulfur-, iron-, or $\mathrm{CO}_{2}$-bearing lithologies.

Reef-type and contact-type deposits, in particular those in the Bushveld Complex, South Africa, are the world's primary source of platinum and rhodium (tables 2 and 3; fig. 2). Reef-type PGE deposits are mined only in the Bushveld Complex (Merensky Reef and UG2), the Stillwater Complex (J-M Reef), and the Great Dyke (Main Sulphide Layer). PGE-enriched contact-type deposits are only mined in the Bushveld Complex. The other deposits in tables 2 and 3 are undeveloped; some are still under exploration. 


\section{Commodities (By-Products)}

Reef-type PGE deposits: primarily platinum, palladium, and rhodium; copper, nickel, ruthenium, iridium, osmium, and gold will be recovered as by-products.

Contact-type Cu-Ni-PGE deposits: polymetallic, with variable proportions of copper, nickel, and platinum-group elements, and by-product gold.

\section{Associated Deposit Types}

Associated deposit types include stratiform chromitite (Schulte and others, 2010), stratiform titanium-vanadium (Force, 1991), and magmatic sulfide-rich nickel-copper deposits related to picrite and (or) tholeiitic basalt dike-sill complexes (Schulz and others, 2010).

\section{Ore System Components}

The exsolution of immiscible sulfide liquid from mafic silicate magma is the fundamental oreforming process in the genesis of PGE mineralization in layered igneous intrusions. Once droplets of immiscible sulfide liquid form in silicate magma, they act as "collectors" for copper, nickel, and PGE because these elements will be preferentially concentrated into the sulfide liquid relative to the silicate liquid.

The solubility of sulfur in mafic magmas is affected by changes in the bulk composition of the magma, the fugacity of sulfur and oxygen, temperature, and pressure. Once magma becomes saturated in sulfur, it can exsolve an immiscible sulfide liquid. Processes that change the solubility of sulfur and may cause an exsolution event include fractional crystallization of the silicate magma, mixing of magmas, assimilation of sulfur from sources external to the magma, and modification of magma composition by bulk contamination, for example, changing the silica content.

Layered igneous intrusions hosting reef-type and contact-type deposits are found in geologic settings characterized by the rapid emplacement of voluminous amounts of mafic and ultramafic magma into continental crust. Depleted, lithospheric mantle stabilized beneath cratons can generate PGE-rich "second-stage" melts that may be important in generating these types of deposits (Mungall, 2005; Green and Peck, 2005; Naldrett, 2010a, b).

\section{Regional Environment}

With one exception, ultramafic to mafic layered intrusions that host reef-type PGE and contacttype $\mathrm{Cu}-\mathrm{Ni}$-PGE deposits are associated with large igneous province (LIP) magmatism (fig. 3, table 4). On continents, LIP-associated rocks include continental flood basalts, aerially extensive mafic dike swarms, sill provinces, and large layered ultramafic to mafic intrusions (Coffin and Eldholm, 1994). Bryan and Ernst (2008) proposed that "Large Igneous Provinces are magmatic provinces with areal extents $>1 \times 10^{5} \mathrm{~km}^{2}$, igneous volumes $>1 \times 10^{5} \mathrm{~km}^{3}$ and maximum lifespans of $<50$ Myr that have intraplate tectonic settings or geochemical affinities, and are characterized by igneous pulse(s) of short duration ( $<1-5 \mathrm{Myr}$ ), during which a large proportion ( $>75$ percent) of the total igneous volume has been emplaced. They are dominantly mafic, but also can have significant ultramafic and silicic components, and some are dominated by silicic magmatism."

Unlike the vast majority of igneous rocks that are associated with plate tectonic processes at convergent or divergent tectonic plate margins, LIP-related igneous rocks usually occur in an intraplate tectonic setting. Some LIPs are linked to hotspot tracks; for example, the North Atlantic Igneous 
Province has been linked to the Iceland hotspot (Storey and others, 2007). Regional uplift and doming may be another characteristic of these provinces.

Within a LIP, layered igneous intrusions hosting reef-type PGE and contact-type Cu-Ni-PGE deposits range in size from plutons covering about $100 \mathrm{~km}^{2}$ to lopoliths that exceed $50,000 \mathrm{~km}^{2}$ in extent. For example, the Skaergaard Intrusion in Greenland that hosts the Platinova Reef is an irregular, $11 \times 8 \mathrm{~km}$, oval-shaped body (Nielson, 2004). The Bushveld Complex, South Africa, is the world's largest layered mafic intrusion, extending more than $350 \mathrm{~km}$ in both north-south and east-west directions (Webb and others, 2004). These intrusions display igneous layering defined by variations in modal proportions of minerals, rock textures, grain size, and mineral compositions. Individual layers range from millimeters to tens of meters in thickness and may extend for hundreds of kilometers along strike. The thickness of the layered intrusions ranges from hundreds of meters to as much as $10 \mathrm{~km}$.

Layered ultramafic and mafic intrusions are studied using stratigraphic mapping techniques. Sections of layered igneous rock are measured and the thickness of layers, along with their composition and textures, are described. Layers are grouped into stratigraphic units that are distinguished on geologic maps. Stratigraphic sections and the resulting maps are used to describe the distribution and geometry of the layered igneous rocks and to understand the crystallization history of the intrusion.

Fractionation patterns in PGE-bearing layered igneous intrusions indicate some were emplaced and solidified as closed systems, whereas others show evidence for repeated injections of magma. An example of a closed system would be the Skaergaard Intrusion, Greenland (McBirney, 1995). The intrusion crystallized inward from the bottom, the sides, and the top, with the last fractionated magmas solidifying in a "sandwich" horizon. Changes in mineral composition with stratigraphic position show trends and patterns consistent with the expected crystallization pattern of a mafic magma. Most of the large layered igneous intrusions, such as the Bushveld Complex, the Stillwater Complex, and the Great Dyke show evidence for open-system behavior. The stratigraphic record for these intrusions show thick intervals in which mineral compositions do not change, abrupt changes in mineral crystallization orders, and discontinuities in fractionation trends that are not consistent with the expected crystallization of a mafic magma.

\section{Age Range}

These deposit types occur throughout Earth's history, but seventy-five percent of known PGE resources occur in three Paleoproterozoic and Neoarchean intrusions: the Bushveld, Great Dyke, and Stillwater (Naldrett, 2010b). Absolute age information for many of the intrusions hosting reef-type and contact-type deposits is summarized in table 4. With the exception of two Tertiary intrusions, La Perouse in Alaska and Skaergaard in Greenland, all intrusions are Mesoproterozoic and older.

\section{Deposit Features}

\section{Reef-Type PGE}

Reef-type PGE deposits consist of stratabound disseminated iron-, copper-, nickel-, and PGEbearing sulfide minerals that are associated with one or more layers within a layered igneous intrusion (table 3). The host rocks for the disseminated sulfide minerals include silicate cumulates such as (1) plagioclase-olivine cumulates that host the J-M Reef in the Stillwater Complex, (2) orthopyroxene cumulates that are associated with the Merensky Reef in the Bushveld Complex, and (3) pyroxene cumulates that host the Main Sulphide Zone in the Great Dyke, as well as oxide cumulates such as 
(4) the UG2 chromitite in the Bushveld Complex, and (5) the iron-titanium oxide layers in the Stella Intrusion in South Africa (fig. 1).

The PGE reefs are typically in stratigraphic intervals that mark a major lithologic and petrologic change in the layered igneous intrusion (fig. 4). The Main Sulphide Layer of the Great Dyke in Zimbabwe and the Ferguson Reef of the Munni Muni Complex in Western Australia are found near the contact between the lower parts of the section composed entirely of ultramafic cumulates and the upper parts dominated by mafic cumulates (fig. 4).

The change may also correspond to the appearance or disappearance of a cumulus mineral, particularly where high-magnesium phases reappear in the section above where they had initially stopped crystallizing. The appearance and disappearance of minerals in the stratigraphic section may reflect the normal evolution of silicate magma. For example, cumulus olivine and chromite crystallize early in the sequence, whereas cumulus iron-titanium oxide minerals and apatite characteristically appear in the upper parts of a section of layered igneous rocks, consistent with crystallization of an evolved magma. However, for the J-M Reef of the Stillwater Complex, Montana, reef-type mineralization is associated with the reappearance of magnesian olivine in the stratigraphic section and a change in the crystallization order of silicate and oxide minerals, as interpreted from rock textures.

The J-M Reef (Stillwater), Merensky Reef and UG2 chromitite (Bushveld), Siika-Kämä Reef (Narkaus Intrusion, Finland), and Sompujärvi Reef (Penikat Intrusion, Finland), are found at the base of cyclic units. Cyclic units are sequences of related igneous layers that repeat many times in the stratigraphic section (Jackson, 1970). The lowest rocks in a sequence may be ultramafic cumulates, which in turn grade upwards into gabbroic and anorthositic cumulates. The anorthositic cumulates at the top of one cyclic unit will be overlain by ultramafic rocks of the next cycle.

Petrologic studies of the PGE reefs show that the stratigraphic interval hosting the sulfide mineralization may be characterized by stratigraphic discontinuities in silicate mineral fractionation trends and abrupt changes in the initial ratios of $\mathrm{Nd}$ and $\mathrm{Sr}$ isotopes (fig. 5) in the igneous rocks. The best example of isotopic discontinuities associated with mineralization is the Merensky Reef in the Bushveld Complex (Kruger, 1994; Teigler, 1990).

The interval hosting PGE reefs may also mark the position where the magmas achieved sulfur saturation in the stratigraphic column. This is indicated by the presence of disseminated sulfide minerals or changes in metal ratios, such as Pd/S (Barnes, 1993; Miller and others, 2002; Maier and others, 1996, 2003; Maier, 2005; Maier and Barnes, 2010). Sulfur saturation may be associated with iron-rich cumulate layers, such as chromitites and iron- and titanium-rich magnetite seams, or with iron-rich silicate rocks resulting from the end-stages of fractional crystallization (fig. 6).

Detailed mapping and stratigraphic studies of the igneous layers hosting reef-style mineralization associated with the Merensky Reef (Smith and Basson, 2006), UG2 chromitite in the Bushveld Complex (van der Merwe and Cawthorn, 2005), and with the J-M Reef (Barnes and Naldrett, 1986) in the Stillwater Complex have documented that the younger, overlying stratum does not "conform" to the dip and strike of the older underlying layered igneous rocks (fig. 7). Following South African terminology, these igneous unconformities are called "potholes."

Not every stratabound occurrence of magmatic sulfide minerals in layered igneous rocks contains elevated PGE concentrations. Examples in the Bushveld Complex include the barren stratabound sulfide concentrations in the Pyroxenite Marker Unit and the main magnetite layer in the Bushveld Complex (Harney and others, 1990; Maier and others, 2001; Barnes and others, 2004; Maier and Barnes, 2010). 


\section{Contact-Type Deposits}

Copper-nickel-PGE-gold contact-type deposits (table 4) consist of disseminated, net-textured, and massive copper-nickel-PGE-enriched sulfide minerals found near the lower contact or margin of mafic to ultramafic layered intrusions. The host rocks for the disseminated sulfide minerals include both the igneous rocks and contact metamorphosed country rocks.

The sulfide mineralization is found adjacent to or along strike with country rocks that are enriched in sulfur-bearing, iron-bearing, and (or) carbonate minerals. The mineralization can be laterally persistent, commonly extending the strike length of the layered igneous intrusion. However, the mineralized interval is generally tens to hundreds of meters in thickness. The proportion of sulfide minerals varies along strike; using economic cut-offs, areas with higher proportions of sulfide minerals and metals are defined as deposits along the contact zone.

Sulfide abundance is typically about 3 to 5 volume percent, but matrix and massive sulfide ores may be present. Erratic variation in the distribution of sulfide minerals is typical, although, the concentration of sulfide minerals within the intrusion generally increases towards its margins and in the adjacent country rocks.

\section{Host Rocks}

\section{Reef-Type Deposits}

The igneous intrusions hosting reef-type PGE deposits almost entirely comprise layered cumulates composed of olivine, orthopyroxene, clinopyroxene, plagioclase, chromite, and Fe-Ti oxide minerals. Igneous rocks can be classified using modal mineralogy (Le Maitre and others, 2002) and color index (leucocratic vs. melanocratic). However, for layered igneous intrusions, cumulus terminology based on modal mineralogy, texture, and composition is also used.

Cumulates are igneous rocks characterized by distinctive textural and compositional features (Jackson, 1967; Irvine, 1982). These rocks consist of high-temperature minerals that crystallize from mafic to ultramafic silicate melts, but in proportions that are not appropriate for the bulk composition of naturally occurring mafic magma. In addition, cumulates are depleted in minerals that crystallize late from magmas and elements that behave incompatibly during crystallization.

Textures of cumulates are characterized by fabrics that consist of a "framework" of anhedral to euhedral crystals (cumulus crystals) "cemented" by minerals interstitial to the cumulus grains (Wager and others, 1960). Postcumulus interstitial material may form crystallographically continuous grains that surround and include cumulus crystals, fill intergranular interstices, or form overgrowths on existing cumulus crystals.

The textural emphasis of cumulus nomenclature documents the sequence of mineral crystallization, which in turn provides a general indication of primary magma composition. For example, the sequence plagioclase-clinopyroxene-olivine or plagioclase-olivine-clinopyroxene is consistent with experimental results for the crystallization sequence of tholeiitic magma. The sequence olivine-clinopyroxene would be consistent with magnesium-rich magmas, such as komatiite. The sequence olivine-orthopyroxene-plagioclase appears to represent the crystallization order of siliceous high-magnesium basaltic magma.

\section{Contact-Type Deposits}

The igneous host rocks of contact-type PGE deposits include cumulate and noncumulus rocks. If the cumulates near the contact are gabbroic, the igneous rocks in the contact zone will be gabbroic. If 
the cumulates near the contact are ultramafic, then the contact zone igneous rocks will be dominated by pyroxenites and norites. Some lithologies are cumulates, but other mineralized mafic and ultramafic igneous rocks are texturally and lithologically heterogeneous, exhibiting changes in texture and mineral proportions on a variety of scales from centimeters to meters. Textures indicative of chilling or unidirectional growth may be present. In literature these rocks are described as vari-textured, heterogeneous texture, or taxitic. Mineral fractionation patterns of ferromagnesian minerals commonly show magnesium enrichment trends upsection, away from the intrusive contact. Inclusions of autholiths and xenoliths are common; they are surrounded by igneous rocks that have textural, mineralogical, and isotopic features suggestive of reaction (Iljina and Lee, 2005). Sulfur isotopic compositions of the sulfide deposits commonly indicate the presence of crustal sulfur. The country rocks are contact metamorphosed and may show evidence for partial melting near the intrusive contact (Johnson and others, 2003; Thomson, 2008).

\section{PGE, Sulfides, and Sulfide Liquid Immiscibility}

The PGE-, copper-, and nickel-bearing sulfide minerals define the ore phases in the igneous rocks. Primary sulfide phases include pyrrhotite, pentlandite, chalcopyrite, and bornite. The sulfide minerals are complexly intergrown and form fine- to coarse-grained aggregates that are molded around and are interstitial to the cumulus or earlier formed silicate minerals, or occur as fine-grained, rounded inclusions in silicate or oxide minerals. The PGE occur in solid solution in sulfide minerals and also as discrete platinum-group minerals (PGM). The PGM can be included in sulfide minerals or chromite, or they can be concentrated along grain boundaries between sulfide minerals or between sulfide and silicate minerals.

Textural and experimental evidence indicate that the PGE-enriched sulfide mineralization formed as an immiscible sulfide liquid that exsolved from mafic to ultramafic magma (Barnes and others, 2008; Holwell and McDonald, 2010; Naldrett, 2010a). When not modified by weathering or alteration, the textures between silicate and sulfide minerals record the distribution and abundance of the sulfide liquids and the interaction between solid silicate minerals and sulfide liquid.

Solubility of sulfur in magma is a function of magma composition and oxygen fugacity; in systems lacking a free sulfide phase, the amount of sulfur dissolved in the silicate melt, $S_{\text {sil }}{ }^{-2}$, follows this mass action equation (Mungal, 2005):

$$
S_{\text {sil }}{ }^{-2}+1 / 2 O_{2}=O_{\text {sil }}{ }^{-2}+1 / 2 S_{2} K_{10}
$$

Assuming that the concentration of $O^{-2}$ does not change appreciably in the silicate melt, the concentration of $S^{-2}$ can be related to a constant similar to an equilibrium constant:

$$
C_{s} \equiv X_{S^{-2}} \times \frac{f O_{2}^{1 / 2}}{f S_{2}^{1 / 2}}=\frac{K_{10}}{X_{O^{-2}}}=\text { constant }
$$

where $C_{S}$ is the sulfide capacity and is a constant for a given melt composition at a given temperature. $C_{S}$

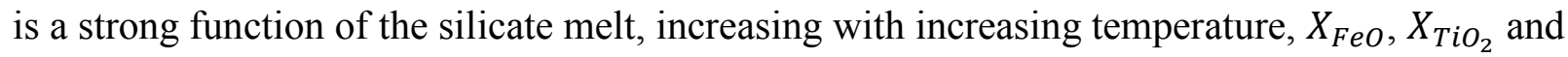
decreases with increasing pressure, $X_{\mathrm{SiO}_{2}}$, and $\mathrm{X}_{\mathrm{Al}_{2} \mathrm{O}_{3}}$ (Mungal, 2005).

Silicate melts become FeS undersaturated as they rise into the crust and fractional crystallization takes place, although assimilation of crustal rocks promotes slight oversaturation. Assimilation of sulfidic sedimentary rocks promotes extreme oversaturation. Magma composition changes that will promote sulfide liquid exsolution can be the result of assimilating sulfur, bulk assimilation of country 
rocks, mixing magmas, or fractional crystallization (Ripley, 1999). Venting the magma chamber can change pressure, which can also promote sulfide liquid immiscibility.

\section{Processes That Determine Composition of Ores}

The metal content of immiscible sulfide liquids is a function of the (1) amount of metal in the silicate magma; (2) relative affinity for metals to occur in the sulfide or silicate liquid, expressed as a partition coefficient; and (3) relative amounts of the two liquids, expressed as a mass ratio of silicate to sulfide liquid (Campbell and Naldrett, 1979; Barnes and Maier, 1999),

$$
C_{\text {sul }}=C_{0} D^{\text {sul } / \text { sil }} \frac{R+1}{R+D^{\text {sul } / \text { sil }}}
$$

where $C_{s u l}$ is the concentration of metal in the sulfide liquid, $C_{0}$ is the initial concentration of the metal in the silicate liquid, $\mathrm{R}$ is the mass ratio of silicate to sulfide liquid, and $D^{\text {sul } / \text { sil }}$ is the partition coefficient of the metal between sulfide and silicate liquid. For example, the initial amount of nickel and copper in the magma will determine the nickel and copper concentrations in the corresponding sulfide liquids and the resulting ores. Komatiitic magmas, with high nickel and low copper concentrations, will give rise to nickel-rich magmatic ores. Tholeiitic magmas, with lower nickel and higher copper, will produce ores with more copper than nickel. The PGE, $\mathrm{Cu}$, and $\mathrm{Ni}$ are chalcophile, and, therefore, they are highly compatible with sulfide melt with respect to silicate melt. Once an immiscible sulfide liquid forms in a silicate melt, chalcophile elements concentrate into the sulfide liquid in proportion to their effective partition coefficients. Estimates of the partition coefficients for $\mathrm{Ni}$ and $\mathrm{Cu}$ between sulfide and silicate liquids are in the hundreds; for the PGE, they range from thousands to tens of thousands (Mungal, 2005; Naldrett, 2010a). The high coefficients, particularly for the PGE, imply that concentration of metals into the sulfide liquid can cause significant drops of the metal in the silicate magma. The distribution equation was modified by Campbell and Naldrett (1979) to allow for differing proportions of magma and sulfide liquid. Low values of the mass ratio of silicate to sulfide liquid are associated with deposits with higher proportions of sulfide minerals and lower concentrations of PGE, which are the contact-type deposits. High values of the mass ratio are associated with deposits with lower proportions of sulfide minerals and high PGE grades, which are the reef-type deposits (Mungall, 2005).

Large mass ratios of silicate to sulfide liquid can be achieved by mixing magmas, migrating interstitial melts (and "fluids") upward through crystal mush, and streaming magma over sulfide liquids in a channelized lava flow, a sill, or feeder dike (Mathez, 1999; Barnes and Maier, 1999; Naldrett, 2010a).

In addition to copper, nickel, PGE, and gold, magmatic ores contain minor amounts of silver, and semi-metals and metalloids such as arsenic, antimony, bismuth, and tellurium.

\section{Mineralogy and Textures}

The textures and mineralogy of the ores record a prolonged and complex process of solid state transformation and recrystallization after solidification of the sulfide liquid at temperatures in excess of $900^{\circ} \mathrm{C}$ (Barnes and others, 2008; Holwell and McDonald, 2010; fig. 8). Depending on the initial composition of the immiscible liquid, the early formed solid products will consist of some mixture of the minerals monosulfide solid solution (MSS), intermediate solid solution (ISS), and bornite solid solution (BNSS). High-temperature monosulfide solid solution exsolves, forming mixtures of pyrrhotite 
and pentlandite. Breakdown products of intermediate solid solution include copper- and iron-bearing sulfide minerals such as chalcopyrite.

At high temperature (about $1,000^{\circ} \mathrm{C}$ ), osmium, iridium, and ruthenium will partition into MSS from the immiscible sulfide liquid. Platinum, palladium, and gold behave as incompatible elements with respect to MSS and are concentrated in residual sulfide liquids. These elements are associated with the final crystallization products of the immiscible sulfide liquid. Upon cooling, some of the PGE that are held in sulfide crystal structure are expelled, forming discrete minerals including sulfides, arsenides, tellurides, antimonides, and alloys. Platinum and gold occur primarily in discrete small PGM, ranging in size from tenths to tens of microns. Significant quantities of palladium can be held in solid solution in pentlandite.

Subsolidus equilibration of sulfide minerals with the enclosing silicate-rich or oxide-rich rock may modify the bulk composition of the sulfide mineral assemblage (Naldrett and von Gruenewaldt, 1989). The greatest change would be expected for sulfide inclusion in silicate or oxide minerals where the sulfide grain size is small, generally tens of microns, and the abundance is low.

Ore textures can be substantially modified by alteration and weathering. Hydrothermal alteration can replace sulfide minerals with actinolite, tremolite, epidote, or calcite (Li and others, 2004). In the UG2, platinum minerals remain within the replacement aureoles after silicate and carbonate minerals replaced the magmatic sulfide minerals. During serpentinization, magnetite can replace sulfide minerals.

Minerals formed during alteration and weathering can include violarite, bornite, mackinawite, cubanite, pyrite, marcasite, troilite, vaesite, smythite, polydymite, millerite, hematite, and magnetite. In supergene environments, chalcocite, malachite, native copper, cuprite, nickel-iron carbonates, nickel and nickel-iron hydroxycarbonates, and nickel-silicates may form. Gossans may form above sulfide-rich rocks.

\section{Variation in PGE and Other Metal Grades}

The distribution and modal abundance is a primary control on the concentrations of copper, platinum, palladium, and gold in reef-type PGE and contact-type deposits. However, the distribution of sulfide minerals is not uniform within a mineralized interval. In addition, the PGE are variably enriched in the sulfide minerals. Stated another way, not every part of a mineralized layer will contain economic quantities of sulfide minerals and the area of greatest abundance of sulfide minerals may not show the highest concentrations of PGE.

\section{Reef-Type PGE-Relation of Thickness of Layer and Grade}

The PGE-rich layer in the Great Dyke, the Main Sulphide Zone, is higher grade where thinner and lower grade where thicker (Wilson and Brown, 2005). The thinner, higher grade parts of this reef are located along the margins of the intrusion. The mineralized layer becomes thicker, but lower grade towards the axis of the dike. Facies of the Merensky Reef and UG2 show similar patterns (figs. 9 and 10); in the Amandebult section, the vertical value distribution of the Merensky Reef decreases as the thickness of the reef increases (Viljoen and others, 1986). However, drill data for the Ferguson Reef in the Munni Munni intrusion and the Stillwater Complex do not show any relation between the thickness of the mineralized interval and its grade (fig. 10).

\section{Reef-Type PGE-Concentration Profiles}

The sulfide mineralization of PGE reefs is stratabound, associated with, but not restricted to a single igneous layer. Vertical profiles through rock layers that host PGE reefs show that the distribution 
of sulfide minerals and their metal concentration is not uniform. The modal abundance of sulfide minerals usually does not vary systematically, instead forming patterns of peaks and troughs that may or may not correspond to layering features. For the Merensky Reef, peaks in copper, PGE, and gold correspond to peaks in the concentration of sulfur in the rock (Wilson and Chunnett, 2006). For the J-M Reef, rocks with the highest modal proportion of sulfide minerals also have the highest PGE concentrations (Zientek and others, 1990; fig. 11). However, several reefs show concentration profiles where the peak concentrations of platinum and palladium are offset stratigraphically below the peak concentrations of sulfur and copper, and thus sulfide mineral abundance. Examples include the Ferguson Reef of the Munni Munni Intrusion (Barnes and others, 1990), the Main Sulphide Layer of the Great Dyke (Naldrett and Wilson, 1990; fig. 12), and the Platinova Reef in the Skaergaard Intrusion (Andersen and others, 1998). An extreme example is the mineralization in Rincon del Tigre in Bolivia where peak concentrations of platinum, palladium, and gold are tens of meters stratigraphically below the highest concentration of copper and sulfide minerals (Prendergast, 2000; fig. 6). For offset-type reefs, small quantities of sulfide minerals below the more voluminous concentrations have the highest PGE concentrations. Sulfide minerals higher in the section, although more abundant, have lower PGE concentrations.

\section{Reef-Type PGE-Variation Along Strike}

Sulfide minerals are not always concentrated uniformly in the plane of layering of reef-type deposits. The reef deposits are characterized by both near- and long-range variability in sulfide mineral abundance and PGE grade. The variation partly reflects difficulties in obtaining representative samples for analysis, but also includes actual differences in the abundance of sulfide minerals and their PGE enrichment along strike.

Resource estimates for reef-type deposits are determined by drilling and assaying drill core or cuttings. In practice, a large disparity in PGE grades may be found between adjacent samples due to the complex, erratic, and localized distribution of sulfide minerals and PGM. This "nugget effect" makes it difficult to estimate grade for reefs. The strategy for minimizing this problem is to increase the density of drilling and the use of replicate analysis of the samples. Replication strategies include analyzing different splits of the drill core, reanalyzing pulps, and using wedges to deflect the bit in a drill hole to obtain several closely spaced samples of a potentially mineralized interval.

After the "nugget effect" is minimized, drilling and mapping show variation in the abundance of sulfide minerals and their grade that can be measured on the scale of tens of meters. Early in the development of the Stillwater mine, about one-third of the definition drill holes on the J-M Reef, drilled on 15 -m centers, did not encounter significant mineralized zones. By selectively mining approximately 30 to 40 percent of the volume of the reef, 80 percent of the contained metal was recovered (R.W. Vian, oral commun., 1989; see also Raedeke and Vian, 1986). Lateral variations in PGE grade are also characteristic of the Merensky Reef and the UG2 chromitite in the Bushveld Complex. Local variations, on the scale of an individual mine property, require closely spaced drilling to estimate resources and develop mine plans (Viljoen and Hieber, 1986; Gray and others, 2008;

fig. 13).

Regional-scale variations in the overall grade of the mineralized interval are also evident when grades are mapped for mine properties. For the Bushveld Complex, there is significant variation in the grade in Merensky Reef and the UG2 along strike, although mines tend to have higher grades in the western part of the intrusion (figs. 14 and 15). 


\section{Contact-Type Deposits}

The absolute PGE contents and relative proportions of PGE content to the base metals vary erratically in these deposits (Iljina and Lee, 2005). Sulfide mineral distribution is patchy, forming clouds of clot-like sulfide mineral aggregates interstitial to igneous silicate minerals. Mineralized units tens of meters thick can be correlated between drill holes. However, individual clouds or lenses of mineralization have limited continuity (usually less than the drill spacing). Along the contact of the intrusion, the sulfide minerals are concentrated into discrete areas or domains that can be delineated as separate deposits (Peterson and others, 2004). In individual drill holes, the highest PGE values can be found tens of meters above or below the contact of the intrusion; they are also variable along the strike (Iljina and Lee, 2005). The highest concentration of PGE is not necessarily associated with the highest concentration of sulfide minerals (Zientek, 1993; Iljina and Lee, 2005).

\section{Geophysical Characteristics for Exploration}

Geophysical methods map physical property contrasts, primarily sulfide minerals, and magnetite that may be associated with mineralization, but not PGE directly (Balch, 2005). Detailed aeromagnetic surveys are used to establish a geologic framework of an area (Campbell, 2006) and generally do not give direct indication of mineralized rock. High-resolution surveys can be used to map igneous layering and tectonic structures, particularly if the data are enhanced to distinguish subtle features. Gravity studies are used to determine the subsurface extent of rocks with variable density and are particularly well suited to map and model the extent and volume of mafic and ultramafic igneous rocks (Webb and others, 2004). However, gravity measurements are not used to directly locate mineralized rocks.

Electrical methods work best on rocks that are conductive. For contact-type deposits, airborne and ground electromagnetics and induced polarization surveys can be used to identify and delineate rocks that contain conductive and interconnected net-textured or massive sulfide ores. For reef-type ores, with low sulfide mineral contents, electrical responses are subtle (Balch, 2005).

Once a rock layer that contains reef-type mineralization has been identified, seismic studies can be used to map the subsurface extent of the rocks. Three-dimensional seismic surveys can identify faults, slumps, and potholes that affect the Merensky Reef (Davison and Chunnett, 1999; Chunnett and Rompel, 2004).

\section{Geochemical Characteristics for Exploration}

The best guide to ore is the presence of sulfide minerals and their iron-oxide replacement products. However, a practical and effective exploration approach is to look for anomalous concentrations of copper, platinum, and palladium in residual or transported material derived from a larger volume of rock. The Merensky Reef was discovered in 1924 as the result of panning in a dry river bed and finding platinum minerals in the concentrate (Cawthorn, 1999). The J-M Reef of the Stillwater Complex was discovered in 1974 by analyzing soil and talus fines for platinum and palladium (Conn, 1979; Zientek and others, 2005; fig. 16). Over 10,900 samples were collected and analyzed; more than 95 percent of them had less than 30 to 40 parts per billion (ppb) palladium and less than 40 to $50 \mathrm{ppb}$ platinum. Most of the anomalous samples had 40 to $200 \mathrm{ppb}$ palladium and 50 to $200 \mathrm{ppb}$ platinum. Highly anomalous samples could have thousands of parts per billion platinum and palladium. Soil chemistry is also used to delineate mineralization in the Platreef (Frick, 1985). Regional glacial till geochemical surveys are being used to explore for contact-type mineralization in the Duluth Complex (Duluth Metals, 2011). 
Assimilation of country rocks is proposed to be an important mechanism for initiating the exsolution of immiscible sulfide liquids in contact-type deposits. Sulfur isotopes, various radiogenic isotopes, and sulfur-selenium ratios are used to study assimilation processes in contact-type ores (Ripley, 1999; Iljina and Lee, 2005). Mantle-derived sulfur has $\delta^{34} \mathrm{~S}$ values near zero per mil. Contacttype mineralization may have $\delta^{34} \mathrm{~S}$ values intermediate between mantle values and values characteristic of sulfur in adjacent metasedimentary rocks. For example, in the Dunka Road contact-type deposit in the Duluth Complex, the $\delta^{34} \mathrm{~S}$ values of sulfides in the mineralized troctolites range from 0.2 to 15.8 per mil, with an average value near 7.5 per mil. Pyrrhotite in the underlying Virginia Formation hornfels and pyrite from unmetamorphosed Virginia Formation are characterized by a similar range in $\delta^{34} \mathrm{~S}$ values (Ripley, 1981). Sr-isotope and Nd-isotope studies of the Platreef in the Bushveld Complex are consistent with local contamination of an already contaminated magma (Pronost and others, 2008).

\section{Deposit Size and Grade Characteristics}

\section{Reef-Type PGE Deposits}

The average grades of PGE reefs that are being mined or actively explored, expressed as the sum of all PGE and gold, range from about 3 to $20 \mathrm{~g} / \mathrm{t}$ (table 2; figs. 17 and 18). The thickness of the mineralized layers range from less than $1 \mathrm{~m}$ to about $25 \mathrm{~m}$. Grades and thickness vary within a deposit along strike. The reef-type PGE deposits vary considerably in grades of platinum, palladium, rhodium, and gold.

Tonnages of PGE reefs are positively correlated with the size of the layered igneous intrusion (Green and Peck, 2005; Naldrett, 2010a). For example, the areal extent of the Bushveld Complex is about $60,000 \mathrm{~km}^{2}$ and about 4.2 billion tons of ore have been identified for the Merensky Reef. The Stillwater Complex has an aerial extent of approximately $200 \mathrm{~km}^{2}$; the total resource delineated for the J-M Reef is about 320 million tons.

\section{Contact-Type Deposits}

Contact-type mineralization is not uniformly concentrated in the igneous and country rocks near the margin of a layered intrusion. During exploration, economic cut offs are used to define the margins of deposits; low grade mineralization may occur outside the cut-off limit that defines deposits. The cutoff criteria used for resource estimation varies by deposit and includes grade, metal-equivalent values, gross metal value (GMV), net metal value (NMV), and metal density (table 5). In table 3, resources for sites within $1 \mathrm{~km}$ of each other, measured from the outer edge of the economic cut-off boundary, were grouped for reporting purposes.

Histograms, box plots, and normal quantile plots of contact-type deposits are shown in figures 19 and 20 and summary statistics are given in table 6. Missing data in table 3 are a result of nonreporting rather than absence of the commodity. The median value of ore for the 37 known contacttype deposits is 70 million tons, with median grades of 0.16 percent nickel, 0.25 percent copper, $0.245 \mathrm{~g} / \mathrm{t}$ platinum, $0.62 \mathrm{~g} / \mathrm{t}$ palladium, and $0.0846 \mathrm{~g} / \mathrm{t}$ gold. The frequency distributions for tonnage and grade are positively skewed but can be normalized, using a log transformation, in order to use parametric statistical tests. Copper, nickel, platinum, and palladium frequency distributions for contacttype deposits are multi-modal as shown by multiple peaks on the histograms and changes in slope on the normal quantile plots. The populations appear to be related to deposits associated with an intrusion or intrusions derived from the same LIP event (figs. 20, 21, and 22). For example, analysis of variance shows that tonnage and the concentrations of copper, platinum, and palladium in deposits associated 
with the Bushveld, Keewenawan, and Baltica LIP events are characterized by statistically distinct distributions (figs. 20 and 21). Resource estimation using all 37 deposits as a universal grade and tonnage model is not appropriate. If enough data are available, grade and tonnage models should be developed for each LIP event for which there is data.

\section{Acknowledgments}

Doug Causey provided results of his compilation of mineral resource data for the Bushveld Complex. Reviews by Rich Goldfarb and Ryan Taylor substantially improved the manuscript. Ken Assmus, Heather Overstreet, and Kassandra Lindsey helped prepare illustrations for the report.

\section{References Cited}

Abbott, D.H., and Isley, A.E., 2002, The intensity, occurrence, and duration of superplume events and eras over geological time: Journal of Geodynamics v. 34, p. 265-307.

Andersen, J.C.Ø., Rasmussen, H., Nielsen, T.F.D., and Ronsbo, J.C., 1998, The Triple Group and the Platinova gold and palladium reefs in the Skaergaard Intrusion: stratigraphic and petrographic relations: Economic Geology, v. 93, p. 488-509.

Arndt, N.T., Nelson, D.R., Compston, W., Trendall, A.F., and Thorne, A.M., 1991, The age of the Fortescue Group, Hamersley Basin, Western Australia, from ion microprobe zircon U-Pb results: Australian Journal of Earth Sciences, v. 38, no. 3, p. 261-281.

Balch, S.J., 2005, Chapter 12: The geophysical signatures of PGE deposits, in Mungall, J.E., ed., 2005 , Exploration for platinum-group element deposits: Ottawa, Mineralogical Association of Canada Short Course Series Volume 35, p. 275-285.

Barnes, S.J., 1993, Partitioning of the PGE and gold between silicate and sulphide magmas in the Munni Munni Complex, Western Australia: Geochimica et Cosmochimica Acta, v. 57, p. 1277-1290.

Barnes, S.-J., and Maier, W.D., 1999, The fractionation of $\mathrm{Ni}, \mathrm{Cu}$ and the noble metals in silicate and sulphide liquids, in Keays, R.R., Lesher, C.M., Lightfoot, P.C., and Farrow, C.E.G., eds., Dynamic processes in magmatic ore deposits and their application in mineral exploration: Geological Association of Canada Short Course Volume 13, p. 69-106.

Barnes, S.J., and Naldrett, A.J., 1986, Geochemistry of the J-M Reef of the Stillwater Complex, Minneapolis Adit Area II. Silicate mineral chemistry and petrogenesis: Journal of Petrology, v. 27, no. 4, p. 791-825.

Barnes, S.-J., Maier, W.D., and Ashwahl, L.D., 2004, Platinum-group element distribution in the Main Zone and Upper Zone of the Bushveld Complex, South Africa: Chemical Geology, v. 208, no. 1-4, p. 293-317.

Barnes, S.J., McIntyre, J.R., Nisbet, B.W., and Williams, C.R., 1990, Platinum group element mineralization in the Munni Munni Complex, Western Australia: Mineralogy and Petrology, v. 42, no. 1-4, p. 141-164.

Barnes, S.-J., Prichard, H.M., Cox, R.A., Fisher, P.C., and Godel, Belinda, 2008, The location of the chalcophile and siderophile elements in platinum-group ore deposits (a textural, microbeam and whole rock geochemical study): Implications for the formation of deposits: Chemical Geology, v. 248, p. 295-317.

Bryan, S.E., and Ernst, R.E., 2008, Revised definition of large igneous provinces (LIPs): Earth-Science Reviews, v. 86, p. 175-202. 
Campbell, Geoff, 2006, High resolution aeromagnetic mapping of "loss-of-ground" features at platinum and coal mines in South Africa: South African Journal of Geology, v. 109, no. 4, p. $439-458$.

Campbell, I.H., and Naldrett, A.J., 1979, The influence of silicate:sulfide ratio on the geochemistry of magmatic sulfides: Economic Geology, v. 74, p. 1503-1505.

Cawthorn, R.G., 1999, The discovery of the platiniferous Merensky Reef in 1924: South African Journal of Geology, v. 102, no. 3, p. 187-183.

Chunnett, G.K., and Rompel, A.K.K., 2004, Data integration for structural interpretation in the Bushveld Complex: The South African Institute of Mining and Metallurgy, International Platinum Conference "Platinum Adding Value," p. 265-268.

Coffin, M.F., and Eldholm, Olav, 1994, Large igneous provinces-Crustal structure, dimensions, and external consequences: Reviews in Geophysics, v. 32, p. 1-36.

Conn, H.K., 1979, The Johns-Manville platinum palladium prospect, Stillwater Complex, Montana, U.S.A.: Canadian Mineralogist, v. 17, p. 463-468.

Davison, G.E., and Chunnett, G.K., 1999, Seismic exploration for Merensky Reef; the way ahead: South African Journal of Geology, v. 102, no. 3, p. 261-267.

Duluth Metals, 2011, Duluth Metals commences drilling program on platinum targets in the Land O’Dixie property: Duluth Metals News Release, August 02, 2011, accessed September 15, 2011, at http://www.duluthmetals.com/s/NewsReleases.asp?ReportID=469433\&_Title=Duluth-MetalsCommences-Drilling-Program-on-Platinum-Targets-on-the-Land-OD.

Ernst R.E., and Buchan, K.L., 2001, Large mafic magmatic events through time and links to mantle plume heads, in Ernst, R.E., and K.L. Buchan, eds., Mantle plumes: Their identification through time: Geological Society of America Special Paper 352, p. 483-575

Ernst, R.E., Buchan, K.L., and Campbell, I.H., 2005, Frontiers in large igneous province research: Lithos, v. 79, p. 271-297.

Farquhar, James, 1986, The Western platinum mine, in Anhaeusser, C.R., and Maske, S., eds., Mineral deposits of Southern Africa, v. 2: Johannesburg, Geological Society of South Africa, p. 1135-1142.

Fetter, A.H., 1999, U/Pb and $\mathrm{Sm} / \mathrm{Nd}$ geochronological constraints on the crustal framework and geological history of Ceará state, NW Borborema Province, NE Brazil: implications for the assembly of Gondwana: Lawrence, Kans., University of Kansas, PhD dissertation, 164 p.

Force, E.R., 1991, Geology of titanium-mineral deposits: Geological Society of America Special Paper 259, $112 \mathrm{p}$.

Frick, C., 1985, A study of the soil geochemistry of the Platreef in the Bushveld Complex: Journal of Geochemical Exploration, v. 24, no. 1, p. 51-80.

Gray, D.B., Rip, B.C., and Smithies, S.N., 2008, Technical report: Lebowa platinum mine, Limpopo Province, South Africa: Johannesburg, Snowden on behalf of Anooraq Resources Corporation, April 2008, $154 \mathrm{p}$.

Green, Tony, and Peck, Dave, 2005, Chapter 11: Platinum-group elements exploration: economic considerations and geological criteria, in Mungall, J.E., ed., 2005, Exploration for platinum-group element deposits: Ottawa, Mineralogical Association of Canada Short Course Series Volume 35, p. 247-274.

Hamilton, M.A., and Brooks, C.K., 2004, A precise U-Pb zircon age for the Skaergaard Intrusion: Magmatic cooling history refinement and Palaeogene igneous correlations, East Greenland [abs.]: American Geophysical Union, Spring Meeting 2004, abstract no. V41A-03. 
Harney, D.M.W., Merkle, R.K.W., and von Gruenewaldt, G., 1990, Platinum-group element behavior in the lower part of the upper zone, eastern Bushveld Complex; implications for the formation of the main magnetite layer: Economic Geology, v. 85, no. 8, p. 1777-1789.

Heaman, L.M., and Machado, N., 1992, Timing and origin of midcontinent rift alkaline magmatism, North America: evidence from the Coldwell Complex: Contributions to Mineralogy and Petrology, v. 110, p. 289-303.

Hoaglund, S.A., 2010, U-Pb geochronology of the Duluth Complex and related hypabyssal intrusions: investigating the emplacement history of a large multiphase intrusive complex related to the $1.1 \mathrm{Ga}$ Midcontinent rift: Minneapolis, University of Minnesota M.S. thesis, $112 \mathrm{p}$.

Holwell, D.A., and McDonald, Iain, 2010, A review of the behavior of platinum group elements within natural magmatic sulfide ore systems: Platinum Metals Review, v. 54, no. 1, p. 26-36.

Hudson, Travis, and Plafker, George, 1981, Emplacement age of the Crillon-LaPerouse pluton, Fairweather Range: U.S. Geological Survey Circular 823-B, p. B90-B94.

Huhma, Hannu, Cliff, R.A., Perttunen, Vesa, and Sakko, Matti, 1990, Sm-Nd and Pb isotopic study of mafic rocks associated with Early Proterozoic continental rifting: the Peräpohja schist belt in northern Finland: Contributions to Mineralogy and Petrology, v. 104, p. 369-379.

Iljina, Markku, 1994, The Portimo Layered Igneous Complex, with emphasis on diverse sulphide and platinum-group element deposits: Acta Universitatis Ouluensis, Series A, Scientiae Rerum Naturalium 258, $158 \mathrm{p}$.

Iljina, M.J., and Lee, C.A., 2005, Chapter 4: PGE deposits in the marginal series of layered intrusions, in Mungall, J.E., ed., 2005, Exploration for platinum-group element deposits: Ottawa, Mineralogical Association of Canada Short Course Series Volume 35, p. 75-96.

Irvine, T.N., 1982, Terminology for layered intrusions: Journal of Petrology, v. 23, p. 127-162. Jackson, E.D., 1967, Ultramafic cumulates in the Stillwater, Great Dyke, and Bushveld Intrusions, in Wyllie, P.J., ed., Ultramafic and related rocks: New York, Wiley, p. 20-38.

Jackson, E.D., 1970, The cyclic unit in layered intrusions-A comparison of the repetitive stratigraphy in the ultramafic parts of the Stillwater, Muskox, Great Dyke and Bushveld Complexes: Geological Society of South Africa Special Publication 1, p. 391-424.

James, R.S., Easton, R.M., Peck, D.C., and Hrominchuk, J.L., 2002, The East Bull Lake Intrusive Suite: Remnants of $\mathrm{a} \sim 2.48 \mathrm{Ga}$ large igneous and metallogenic province in the Sudbury area of the Canadian Shield: Economic Geology, v. 97, p. 1577-1606.

Johnson, T.E., Gibson, R.L., Brown, Michael, Buick, I.S., and Cartwright, Ian, 2003, Partial melting of metapelitic rocks beneath the Bushveld Complex, South Africa: Journal of Petrology, v. 44, no. 5, p. 789-813.

Kruger, F.J., 1994, The Sr-isotopic stratigraphy of the western Bushveld Complex: South African Journal of Geology, v. 97, p. 393-398.

Kruger, J.F., 2005, Filling the Bushveld Complex magma chamber: lateral expansion, roof and floor interaction, magmatic unconformities, and the formation of giant chromitite, PGE and Ti-V-magnetitite deposits: Mineralium Deposita, v. 40, no. 5, 451-472.

Le Maitre, R.W., ed., Streckeisen, Albert, Zanettin, Bernard, Le Bas, M.J., Bonin, Bruno, and Bateman, P.C., 2002, Igneous rocks: A classification and glossary of terms: Cambridge, United Kingdom, Cambridge University Press, 252 p.

Li, Chusi, Ripley, E.M., Merino, Enrique, and Maier, W.D., 2004, Replacement of base metal sulfides by actinolite, epidote, calcite, and magnetite in the UG2 and Merensky Reef of the Bushveld Complex, South Africa: Economic Geology, v. 99, p. 173-184. 
Loney, R.A., and Himmelberg, G.R., 1983, Structure and petrology of the La Perouse gabbro intrusion, Fairweather Range, southeastern Alaska: Journal of Petrology, v. 24, p. 377-423.

Maier, W.D., 2005, Platinum-group element (PGE) deposits and occurrences: mineralization styles, genetic concepts, and exploration criteria: Journal of African Earth Sciences, v. 41, p. 165-191.

Maier, W.D., and Barnes, S.-J., 2010, The petrogenesis of platinum-group element reefs in the Upper Main Zone of the northern lobe of the Bushveld Complex on the farm Moorddrift, South Africa: Economic Geology, v. 105, no. 4, p. 841-854.

Maier, W.D., Barnes, S.-J., and van der Merwe, M.J., 2001, Platinum-group elements in the Pyroxenite Marker, Bushveld Complex: implications for the formation of the Main Zone: South African Journal of Geology, v. 104, no. 4, p. 301-308.

Maier, W.D., Barnes, S.-J., De Klerk, W.J., Teigler, Bernd, and Mitchell, A.A., 1996, Cu/Pd and Cu/Pt of silicate rocks in the Bushveld Complex: implications for platinum-group element exploration: Economic Geology, v. 91, p. 1151-1158.

Maier, W.D., Barnes, S.-J., Gartz, Volker, and Andrews, G., 2003, Pt-Pd reefs in magnetitites of the Stella layered intrusion, South Africa: a world of new exploration opportunities for platinum-group elements: Geology v. 31, p. 885-888.

Mathez, E.A., 1999, On factors controlling the concentrations of platinum group elements in layered intrusions and chromitites, in Keays, R.R., Lesher, C.M., Lightfoot, P.C., and Farrow, C.E.G., eds., Dynamic processes in magmatic ore deposits and their application in mineral exploration: Geological Association of Canada Short Course Volume 13, p. 251-286.

McBirney, A.R., 1995, Mechanisms of differentiation of the Skaergaard Intrusion: Journal of the Geological Society of London, v. 152, p. 421-435.

Miller, J.D., Green, J.C., Severson, M.J., Chandler, V.W., Hauck, S.A., Peterson, D.M., and Wahl, T.E., 2002, Geology and mineral potential of the Duluth Complex and related rocks of northeastern Minnesota: Minnesota Geological Survey Report of Investigations 58, 207 p.

Mungal, J.E., 2005, Chapter 1: Magmatic geochemistry of the platinum-group elements, in Mungall, J.E., ed., 2005, Exploration for platinum-group element deposits: Ottawa, Mineralogical Association of Canada Short Course Series Volume 35, p. 1-34.

Naldrett, A.J., 2004, Magmatic sulfide deposits-Geology, geochemistry, and exploration: Berlin, Springer-Verlag, $727 \mathrm{p}$.

Naldrett, A.J., 2010a, From the mantle to the bank: The life of a Ni-Cu-(PGE) sulfide deposit: South African Journal of Geology, v. 113, no. 1, p. 1-32.

Naldrett, A.J., 2010b, Secular variation of magmatic sulfide deposits and their source magmas: Economic Geology, v. 105, p. 699-688.

Naldrett, A.J., and von Gruenewaldt, G., 1989, Association of platinum-group elements with chromite in layered intrusions and ophiolite complexes: Economic Geology, v. 84, p. 180-187.

Naldrett, A.J., and Wilson, A.H., 1990, Horizontal and vertical variations in noble metals in the Great Dyke of Zimbabwe: A model for the origin of the PGE mineralization by fractional segregation of sulfide: Chemical Geology, v. 88, nos. 3-4, p. 279-300.

Nielson, T.F.D, 2004, The shape and volume of the Skaergaard Intrusion, Greenland: Implications for mass balance and bulk composition: Journal of Petrology, v. 45, no. 3, p. 507-530.

Nitkina, E.A., 2006, U-Pb zircon dating of rocks of the platiniferous Federova-Pana layered massif, Kola Peninsula: Doklady Earth Sciences, v. 408, no. 4., p. 551-554.

Oberthür, Thomas, Davis, D.W., Blenkinsop, T.G., and Höhndorf, Axel, 2002, Precise U-Pb mineral ages, $\mathrm{Rb}-\mathrm{Sr}$ and Sm-Nd systematics for the Great Dyke, Zimbabwe-constraints on Late Archean events in the Zimbabwe craton and Limpopo belt: Precambrian Research, v. 113 no. 3-4, p. 293-305. 
Page, R.W., and Hoatson, D.M., 2000, Geochronology of the mafic-ultramafic intrusions, in Hoatson, D.M., and Blake, D.H., eds., Geology and economic potential of the Palaeoproterozoic layered maficultramafic intrusions in the East Kimberley, Western Australia: Australian Geological Survey Organisation Bulletin 246, p. 163-172.

Peterson, D.M., Patelke, R.L., and Severson, M.J., 2004, Bedrock geology map and Cu-Ni mineralization data for the basal contact of the Duluth Complex west of Birch Lake, St. Louis and Lake Counties, Northeastern Minnesota: University of Minnesota Duluth, Natural Resources Research Institute, NRRI/MAP-2004/02, accessed September 27, 2011, at http://www.nrri.umn.edu/egg/REPORTS/MAP200402/NRRIMAP200402.zip.

Premo, W.R., Helz, R.T., Zientek, M.L., and Langston, R.B., 1990, U-Pb and Sm-Nd ages for the Stillwater Complex and its associated sills and dikes, Beartooth Mountains, Montana; identification of a parent magma?: Geology, v. 18, no. 11, p. 1065-1068.

Prendergast, M.D., 2000, Layering and precious metals mineralization in the Rincón del Tigre Complex, eastern Bolivia: Economic Geology, v. 95, no. 1, p. 113-130.

Pronost, Julie, Harris, Chris, and Pin, Christian, 2008, Relationship between footwall composition, crustal contamination, and fluid-rock interaction in the Platreef, Bushveld Complex, South Africa: Mineralium Deposita, v. 43, no. 8, p. 825-848.

Raedeke, L.D., and Vian, R.W., 1986, A three dimensional view of mineralization in the Stillwater J-M Reef: Economic Geology, v. 81, no. 5, p. 1187-1195.

Ripley, E.M., 1981, Sulfur isotopic studies of the Dunka Road Cu-Ni deposit, Duluth Complex, Minnesota: Economic Geology, v. 76, no. 3, p. 610-620.

Ripley, E.M., 1999, Systematics of sulphur and oxygen isotopes in mafic igneous rocks and related CuNi-PGE mineralization, in Keays, R.R., Lesher, C.M., Lightfoot, P.C., and Farrow, C.E.G., eds., Dynamic processes in magmatic ore deposits and their application in mineral exploration: Geological Association of Canada Short Course Volume 13, p. 133-158.

Schulz, K.J., Chandler, V.W., Nicholson, S.W., Piatak, N., Seal, R.R., II, Woodruff, L.B., and Zientek, M.L., 2010, Magmatic sulfide-rich nickel-copper deposits related to picrite and (or) tholeiitic basalt dike-sill complexes: U.S. Geological Survey Open-File Report 2010-1179, 25 p., available at http://pubs.usgs.gov/of/2010/1179/.

Schulte, R.F., Taylor, R.D., Piatak, N.M., and Seal, R.R., II, 2010, Stratiform chromite deposit model: U.S. Geological Survey Open-File Report 2010-1232, 7 p.

Scoates, J.S., and Friedman, R.M., 2008, Precise age of the platiniferous Merensky Reef, Bushveld Complex, South Africa, by the U-Pb zircon chemical abrasion ID-TIMS technique: Economic Geology, v. 103, no. 3, p. 465-471.

Smith, D.S., and Basson, I.J., 2006, Shape and distribution analysis of Merensky Reef, Northam Platinum Mine, western Bushveld complex: Implications for pothole formation and growth: Mineralium Deposita v. 41, no. 3, p. 281-295.

Storey, Michael, Duncan, R.A., and Tegner, Christian, 2007, Timing and duration of volcanism in the North Atlantic Igneous Province: Implications for geodynamics and links to the Iceland hotspot: Chemical Geology, v. 241, nos. 3-4, p. 264-281.

Teigler, Bernd, 1990, Platinum-group element distribution in the Lower and Middle Group chromitites in the western Bushveld Complex: Mineralogy and Petrology, v. 42, p. 165-179.

Thomson, J.A., 2008, Beneath the Stillwater Complex: Petrology and geochemistry of quartzplagioclase bearing cordierite (or garnet) - orthopyroxene $+/$ - spinel hornfels, Mountain View area, Montana: American Mineralogist, v. 93, p. 438-450. 
van der Merwe, J., and Cawthorn, R.G., 2005, Structures at the base of the Upper Group 2 chromitite layer, Bushveld Complex, South Africa, on Karee Mine (Lonmin Platinum): Lithos, v. 83, nos. 3-4, p. 214-228.

Viljoen, M.J., 1999, The nature and origin of the Merensky Reef of the western Bushveld Complex based on geological facies and geophysical data: South African Journal of Geology, v. 102, no. 3, p. 221-239.

Viljoen, M.J., and Hieber, R.W., 1986, The Rustenburg section of Rustenburg Platinum Mines Limited, with reference to the Merensky Reef, in Anhaeusser, C.R., and Maske, S., eds., Mineral deposits of southern Africa, v. 2: Johannesburg, Geological Society of South Africa, p. 1107-1134.

Viljoen, M.J., Theron, J., Underwood, B., Walters, B.M., Weaver, J., and Peyerl, W., 1986, The Amandelbult section of Rustenburg Platinum Mines Limited, with reference to the Merensky Reef, in Anhaeusser, C.R., and Maske, S., eds., Mineral deposits of southern Africa, v. 2: Johannesburg, Geological Society of South Africa, p. 1041-1060.

Wager, L.R., Brown, G.M., and Wadsworth, W.J., 1960, Types of igneous cumulates: Journal of Petrology, v. 1. p. 73-85.

Webb, S.J., Cawthorn, R.G., Nguuri, Teresia, and James, David, 2004, Gravity modeling of Bushveld connectivity supported by southern Africa seismic experiment results: South African Journal of Geology, v. 107, no. 1-2, p. 207-218.

Wilson, A.H., and Brown, R.T., 2005, Chapter 19: Exploration and mining of the main sulphide zone of the Great Dyke, Zimbabwe - Case study of the Hartley Platinum Mine, in Mungall, J.E., ed., 2005, Exploration for platinum-group element deposits: Ottawa, Mineralogical Association of Canada Short Course Series Volume 35, p. 400-429.

Wilson, Alan, and Chunnett, Gordon, 2006, Trace element and platinum group element distributions and the genesis of the Merensky Reef, western Bushveld Complex, South Africa: Journal of Petrology, v. 47, no. 12, p. 2369-2403.

Zientek, M.L., 1993, Mineral resource appraisal for locatable minerals: the Stillwater Complex, in Hammarstrom, J.M., Zientek, M.L., and Elliott, J.E., eds., Mineral resource assessment of the Absaroka-Beartooth study area, Custer and Gallatin National Forests, Montana: U.S. Geological Survey Open-File Report 93-207, p. F1-F83.

Zientek, M.L., Corson, S.R., and West, R.D., 2005, Chapter 18: Geochemical surveys of soil and talus fines and the discovery of the J-M Reef, Stillwater Complex, Montana, in Mungall, J.E., ed., 2005, Exploration for platinum-group element deposits: Ottawa, Mineralogical Association of Canada Short Course Series Volume 35, p. 391-407.

Zientek, M.L., Fries, T.L., and Vian, R.W., 1990, As, Bi, Hg, S, Sb, Sn, and Te geochemistry of the J-M Reef, Stillwater Complex, Montana: Constraints on the origin of PGE-enriched sulfides in layered intrusions: Journal of Geochemical Exploration, v. 37, p. 51-73.

\section{Additional Reading}

This a partial list of books, papers, and digital datasets that summarize magmatic ore deposits, reef-type, and contact-type deposits not cited in this report but that should be part of a reading list for understanding these deposit types.

Barnes, S.-J., and Lightfoot, P.C., 2005, Formation of magmatic nickel sulfide deposits and processes affecting their copper and platinum group element content, in Hedenquist, J.W., Thompson, J.F.H., Goldfarb, R.J., and Richards, J.P., eds., Economic Geology_One hundredth anniversary volume 1905-2005: Littleton, Colo., Society of Economic Geologists, p. 179-213. 
Barrie, C.T., 1995, Magmatic platinum group elements, in Eckstrand, O.R., Sinclair, W.D., and Thorpe, R.I., eds., Geology of Canadian mineral deposit types: Geological Survey of Canada, Geology of Canada Series no. 8, p. 605-614.

Cabri, L.J., ed., 2002, The geology, geochemistry, mineralogy and mineral beneficiation of platinumgroup elements: Canadian Institute of Mining, Metallurgy and Petroleum Special Volume 54, $852 \mathrm{p}$.

Causey, J.D., Galloway, J.P., and Zientek, M.L., 2009, An index to PGE-Ni-Cr deposits and occurrences in selected mineral-occurrence databases: U.S. Geological Open-File Report 2009-1045, available at http://pubs.usgs.gov/of/2009/1045/.

Cawthorn, R.G., ed., 1996, Developments in petrology_Layered intrusions: Amsterdam, Elsevier Science, $531 \mathrm{p}$.

Cawthorn, R.G., Barnes, S.J., Ballhaus, Christian, and Malitch, K.N., 2005, Platinum group element, chromium, and vanadium deposits in mafic and ultramafic rocks, in Hedenquist, J.W., Thompson, J.F.H., Goldfarb, R.J., and Richards, J.P., eds., One hundredth anniversary volume 1905-2005:

Littleton, Colo., Society of Economic Geologists, Inc., p. 215-250.

Eckstrand, O.R., 1995, Nickel-copper sulphide, in Eckstrand, O.R., Sinclair, W.D., Thorpe, R.I., eds., Geology of Canadian mineral deposit types: Geological Survey of Canada, Geology of Canada Series no. 8 , p. 584-605.

Eckstrand, O.R., and Hulbert, L.J., 2007, Magmatic nickel-copper-platinum group element deposits, in Goodfellow, W.D., ed., Mineral deposits of Canada-A synthesis of major deposit-types, district metallogeny, the evolution of geological provinces, and exploration methods: Geological Association of Canada, Mineral Deposits Division, Special Publication No. 5, p. 205-222.

Eckstrand, O.R., Good, D.J., Yakubchuk, A., and Gall, Q., comps., 2004, World distribution of Ni, Cu, PGE, and Cr deposits and camps: Geological Survey of Canada Website, accessed September 17, 2011, at http://gdr.nrcan.gc.ca/minres/index_e.php (also

http://apps1.gdr.nrcan.gc.ca/gsc_minerals/zip/NiPGECr.zip and http://gdr.nrcan.gc.ca/minres/metadata_e.php?id=11).

Eckstrand, O.R., and Hillary, E.M., 2005, World distribution of PGE-bearing mineral deposits: Geological Survey of Canada Contribution Number 2005134, accessed September 17, 2011, at http://www.mineralogicalassociation.ca/doc/PGEposter final.pdf.

Farrow, C.E.G., and Watkinson, D.H., 1999, An evaluation of the role of fluids in Ni-Cu-PGE-bearing, mafic-ultramafic systems, in Keays, R.R., Lesher, C.M., Lightfoot, P.C., and Farrow, C.E.G., eds., Dynamic processes in magmatic ore deposits and their application in mineral exploration: Geological Association of Canada, Short Course Notes, v. 13, p. 31-68.

Hoatson, D.M., Jaireth, Subhash, and Jaques, A.L., 2006, Nickel sulfide deposits in AustraliaCharacteristics, resources, and potential: Ore Geology Reviews, v. 29, p. 177-241.

Hoatson, D.M., Jaireth, Subhash, and Jaques, A.L., 2006, Nickel sulfide deposits in Australia: characteristics, resources, and potential: Ore Geology Reviews, 29, nos. 3/4, p. 177-241.

Hulbert, L.J., Duke, J.M., Eckstrand, O.R., Lydon, J.W., Scoates, R.F.J., Cabri, L.J., and Irvine, T.N., 1988, Geological environments of the platinum group elements: Geological Survey of Canada, Open File 1440, 148 p.

Li, Chusi, Maier, W.D., and de Waal, S.A., 2001, Magmatic Ni-Cu versus PGE deposits - Contrasting genetic controls and exploration implications: South African Journal of Geology, v. 104, p. 309-318.

Maier, W.D., 2005, Platinum-group element (PGE) deposits and occurrences: Mineralization styles, genetic concepts, and exploration criteria: Journal of African Earth Sciences, v. 41, p. 165-191.

Mungall, J.E., ed., 2005, Exploration for platinum-group element deposits: Ottawa, Mineralogical Association of Canada Short Course Series Volume 35, 512 p. 
Naldrett, A.J., 1998, World class Ni-Cu-PGE deposits: Key factors in their genesis: Mineralium Deposita, v. 34, no. 3, p. 227-240.

Wager, L.R., and Brown, G.M., 1967, Layered igneous rocks: San Francisco, Freeman, 588 p.

Wagner, P.A., 1929. The platinum deposits and mines of South Africa: Edinburgh, Oliver \& Boyd, $326 \mathrm{p}$. 


\section{References Cited in Tables 2 and 3}

Abbott, Jr., D.M., Bullock, R.L., Gibbs, Betty, and Kunter, R.S., 2011, Technical report for the mining operations at Stillwater Mining Company, Stillwater Mine, $45^{\circ} 23^{\prime} \mathrm{N}, 109^{\circ} 53^{\prime} \mathrm{W}$, East Boulder Mine,

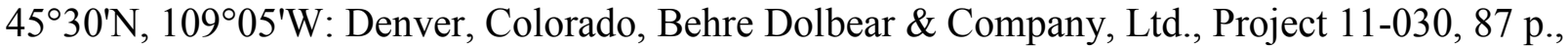
accessed September 15, 2011, at http://services.corporate-

ir.net/SEC/Document.Service? id = P3VybD1odHRwOi8vaXIuaW50Lndlc3RsYXdidXNpbmVzcy5jb20v ZG9jdWIlbnQvdjEvMDAwMTEwMjYyNCOxMSOwMDAzNzkvZG9jL1NOaWxsd2F0ZXJNaW5pbmdD b21wYW55XzhLXzIwMTEwNjIzLnBkZiZ0eXBlPTImZm49U3RpbGx3YXRlck1pbmluZ0NvbXBhbnlfO EtfMjAxMTA2MjMucGRm.

AIM Resources, Ltd., 2005, Annual report: AIM Resources, Ltd., 36 p.

Anglo Platinum, 2006, Analyst and fund manager facility visit 09 November 2006: Anglo Platinum, 54 p., accessed April 27, 2008, at http://www.angloplatinum.com/investor_media/im_presentations/analyst_091106/ analyst_091106.pdf.

Anglo Platinum, 2009, Platinum estimates as of 31 December 2009: Anglo Platinum Annual Report 2009, Ore Reserves and Mineral Resources, accessed September 23, 2011, at http://ar09.angloamerican.solutions.investis.com/ore_reserves/platinum/projects.html.

Barrick, 2008, Annual information form, March 27, 2008: Barrick Gold, available at http://sedar.com/.

Cawthorn, R.G., 1999, The platinum and palladium resources of the Bushveld Complex: South African Journal of Science, v. 95, p. 481-489.

Clow, G.G., Cox, J.J., Routledge, R.E, and Hayden, A.S., 2006, Technical report on the preliminary assessment of the Birch Lake and Maturi deposits, Minnesota, U.S.A: Roscoe Postle Associates, Inc., [Technical Report] for Franconia Mineral Corporation, 175 p.

Czamanske, G.K., Haffty, Joseph, and Nabbs, S.W., 1981, Pt, Pd, and Rh analyses and beneficiation of mineralized mafic rocks from the La Perouse Layered Gabbro, Alaska: Economic Geology, v. 76, p. 2001-2011.

Directorate of Mineral Economics, 2006, An overview of current platinum group metal exploration projects and new mine developments in South Africa: South Africa Directorate of Mineral Economics Report R51/2006, 26 p.

Geological Survey of Finland, 2009, Fennoscandian ore deposit database: Geological Survey of Finland Website, accessed Feb. 10, 2009, at http://en.gtk.fi/ExplorationFinland/fodd/.

Geological Survey of Finland, 2009, Suhanko-NICKEL database: Geological Survey of Finland FINNICKEL Database, accessed September 21, 2011, at http://en.gtk.fi/ExplorationFinland/Commodities/Nickel/suhanko.html.

Geological Survey of Finland, 2009, Vaaralampi-NICKEL database: Geological Survey of Finland FINNICKEL Database, accessed September 21, 2011, at

http://en.gtk.fi/ExplorationFinland/Commodities/Nickel/vaaralampi.html.

Geological Survey of Finland, 2010, Platinum-group elements in Finland: GTK Website, accessed September 23, 2011, at http://en.gtk.fi/ExplorationFinland/Commodities/PGE/pge_database.html.

Himmelberg, G.R., and Loney, R.A., 1981, Petrology of the ultramafic and gabbroic rocks of the Brady Glacier nickel-copper deposit, southeastern Alaska: U.S. Geological Survey Professional Paper 1195, $26 \mathrm{p}$.

Hunter, D.J., 2006, Technical report on the Northmet project: Polymet Mining Corp. [Technical Report], 183 p. 
Iljina, Markku, Heikura, Pertti, and Salmirinne, Heiki, 2005, The Haukiaho and Kaukua PGE-Cu-Ni-Au prospects in the Koillismaa Layered Igneous Complex, Finland: Geological Survey of Finland, Mineral Exploration Report CM06/3543,3544/2005/1/10, 20 p., 3 appendixes.

Lahtinen, Jarmo, 1987, Ni-Cu-PGE-mineralisaation tutkimukset, arvio malmimahdollisuuksista, Ranua, Ahmavaara: Outokumpu Oy report, 001/3522/JJL/87/1.

Lahtinen, Jarmo, 1983, Yhteenveto Koillismaan kerrosintruusiokompleksin platinatutkimuksista: Outokumpu Oy report, 001/3541, 3543, 4523/JJL/83/5.

Lonmin Platinum, 2007, Mineral resources and reserves, 30 September 2007: Lonmin Platinum, 30 p.

Mattila, E., Hugg, R., and Kerkkonen, Olavi, 1976, Mustavaaran kaivoksen jätealtaan Lavotan tutkimukset XI-XII v. 1975: Rautaruukki Oy report OU 1/76.

Miller, J.D., Jr., Green, J.C., Severson, M.J., Chandler, V.W., Hauck, S.A., Peterson, D.M., and Wahl, T.E., 2002, Geology and mineral potential of the Duluth Complex and related rocks of northeastern Minnesota: Minnesota Geological Survey Report of Investigations 58, 207 p., CD-ROM, also available at $h t t p: / / w w w . d . u m n . e d u / \sim m i l l e 066 / P u b l i c a t i o n s / R I$ 58.pdf.

Mitrofanov, F.P., Korchagin, A.U., and Lobov, S.G., 2007, PGE Fedorova project-Russia, Kola peninsula, Lovozero area: accessed February 20, 2010 at

http://www.lapinliitto.fi/fem2007/presentations/14lobov.pdf.

P\&E Mining Consultants, Inc., 2007, Updated technical report and preliminary economic assessment on the Marathon PGM-Cu property, Marathon area, Thunder Bay mining district, Northwestern Ontario, Canada: P\&E Mining Consultants, Inc., NI 443-101 and 43-101F1 Technical Report and Preliminary Economic Assessment for Marathon PGM Corporation, P\&E Report No. 132, 228 p.

Pacific North West Capital Corp., 2006, New resource estimate expands River Valley Resource: Vancouver, B.C., Pacific North West Capital Corp. News Release, March 27, 2006, 4 p.

Pan Palladium Limited, 2005, Annual Report 2005: Pan Palladium Limited, 55 p.

Pan Palladium Limited, 2007, Annual Report 2007: Pan Palladium Limited, 59 p.

Pan Palladium Limited, 2008, Annual Report 2008: Pan Palladium Limited, 57 p.

Parks, Jennifer, 1998, Weld Range platinum group element deposit, in Berkman, D.A., and Mackenzie, D.H., eds., Geology of Australian and Papua New Guinean mineral deposits: Australasian Institute of Mining and Metallurgy Monograph 22, p. 279-286.

Platinum Australia, Ltd., 2003, Annual Report 2003: Platinum Australia, Ltd., 37 p., accessed

September 9, 2004 at http://www.gtp.com.au/platinumaus/inews_files/Final_Annual_Report03.pdf.

Platinum Group Metals, 2008, War Springs resource increased to 1.7 million ounces: Vancouver, B.C., Platinum Group Metals News Release No. 08-151, March 17, 2008, 4 p.

Platina Resources, Ltd., 2010, Munni Munni, WA: Platina Resources, Ltd., Factsheet, accessed September 23, 2011, at

http://www.platinaresources.com.au/files/projects/PC00316_Platina_Factsheet_MUNNI_MUNNI_LR .pdf.

Platina Resources, Ltd., 2010, Skaergaard, East Greenland: Platina Resources, Ltd., Factsheet, accessed September 23, 2011, at http://www.platinaresources.com.au/files/projects/PC00316_Platina_Factsheet_SKAERGAARD_LR. $p d f$.

Puritch, Eugene, Ewert, Wayne, Brown, F.H., Rickard, Jason, and King, David, 2007, Technical report, mineral resource estimate, and preliminary economic assessment (scoping study) of the Suhanko Project, northern Finland: Aker Kvaerner, P\&E Consultants, Inc., and F.H. Brown, NI-43-101F1 Technical Report and Scoping Study for North American Palladium, Ltd., Report No 135, 199 p. 
Reino, J., Ilvonen, E., and Rekola, T., 1978, Suhanko-Pekkala-alueen tutkimuksista 1970-luvulla: Outokumpu Oy report, 001/3522, 3524, 3611, 3613/JR, EI, TPR/78.

Ridge Mining, Plc., 2008, Sheba's Ridge feasibility study update: Ridge Mining, Plc., RNS Number 7365M, 29, January 2008, accessed April 27, 2008, at

http://www.hemscott.com/servlet/HsPublic? context=ir.access\&ir_option $=R N S \_N E W S \& i t e m=589999$ 65807716\&ir_client_id $=3936 \&$ transform $=r n s \_s t o r y$.

Routledge, R.E., 2007, Technical report on the resource estimate for the Nokomis deposit on the Maturi extension properties, Minnesota, U.S.A.: Scott Wilson Roscoe Postle Associates, Inc., NI 43-101; Report prepared for Duluth Minerals Limited, August 8, 2007, 112 p.

Routledge, R.E., 2008, Technical report on the resource estimate for the Birch Lake project: Scott Wilson Roscoe Postle Associates, Inc., August 22, 2008.

Routledge, R.E., and Cox, J.J., 2007, Technical report on the resource estimate for the Spruce Road deposit, Minnesota, U.S.A.: Scott Wilson Roscoe Postle Associates, Inc., NI 43-101; Report prepared for Franconia Minerals Corporation, November 15, 2007, 130 p.

Schissel, Don, Tsvetkov, A.A., Mitrofanov, F.P., and Korchagin, A.U., 2002, Basal platinum-group element mineralization in the Federov Pansky Layered Mafic Intrusion, Kola Peninsula, Russia: Economic Geology, v. 97, p. 1657-1677.

Tulp, Thomas, Stone, D.M., Reeves, David, and van der Heever, G.J., 2005, Preliminary assessment Boikgantsho Joint Venture: Anooraq Resources Corp., Technical Report, 96 p.

U.S. Bureau of Mines, 1991, Mineral investigations on the Juneau Mining District, Alaska, 1984-1988: U.S. Bureau of Mines Special Publication, Volume 1, Executive Summary, 49 p.

Vance, Ron, 2007, Corporate development: Teck Cominco, Website accessed April 28, 2011, at http://www.teckcominco.com/DocumentViewer.aspx?elementId=120718\&portalName $=t c$.

Verbeek, Julian, and Lomber, Ken, 2005, Qualified persons report, Rooipoort PGE, Mokopane, Limpopo Provine, South Africa: RSG Global for Caledonia Mining Corporation, 96 p., accessed September 21, 2011, at http://www.caledoniamining.com/pdfs/CALPres051221.pdf.

Zientek, M.L., 1993, Mineral resource appraisal for locatable minerals: the Stillwater Complex, in Hammarstrom, J.M., Zientek, M.L., and Elliott, J.E., eds., Mineral resource assessment of the Absaroka-Beartooth study area, Custer and Gallatin National Forests, Montana: U.S. Geological Survey Open-File Report 93-207, p. F1-F83. 


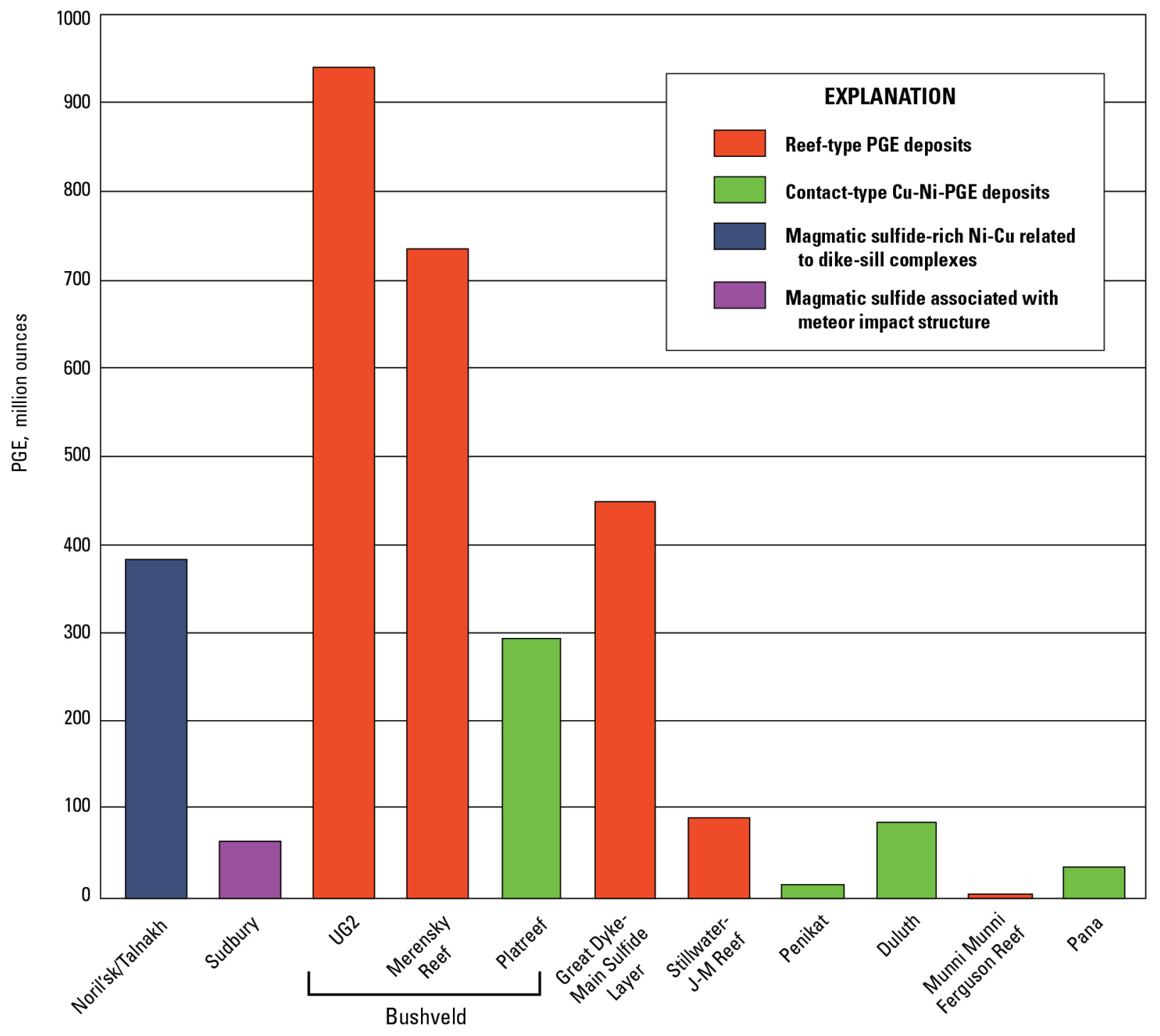

Figure 1. Histogram of the major world platinum-group elements (PGE) deposit resources. Reef-type deposits and contact-type deposits are shown in red and green, respectively. Data from Green and Peck (2005). 


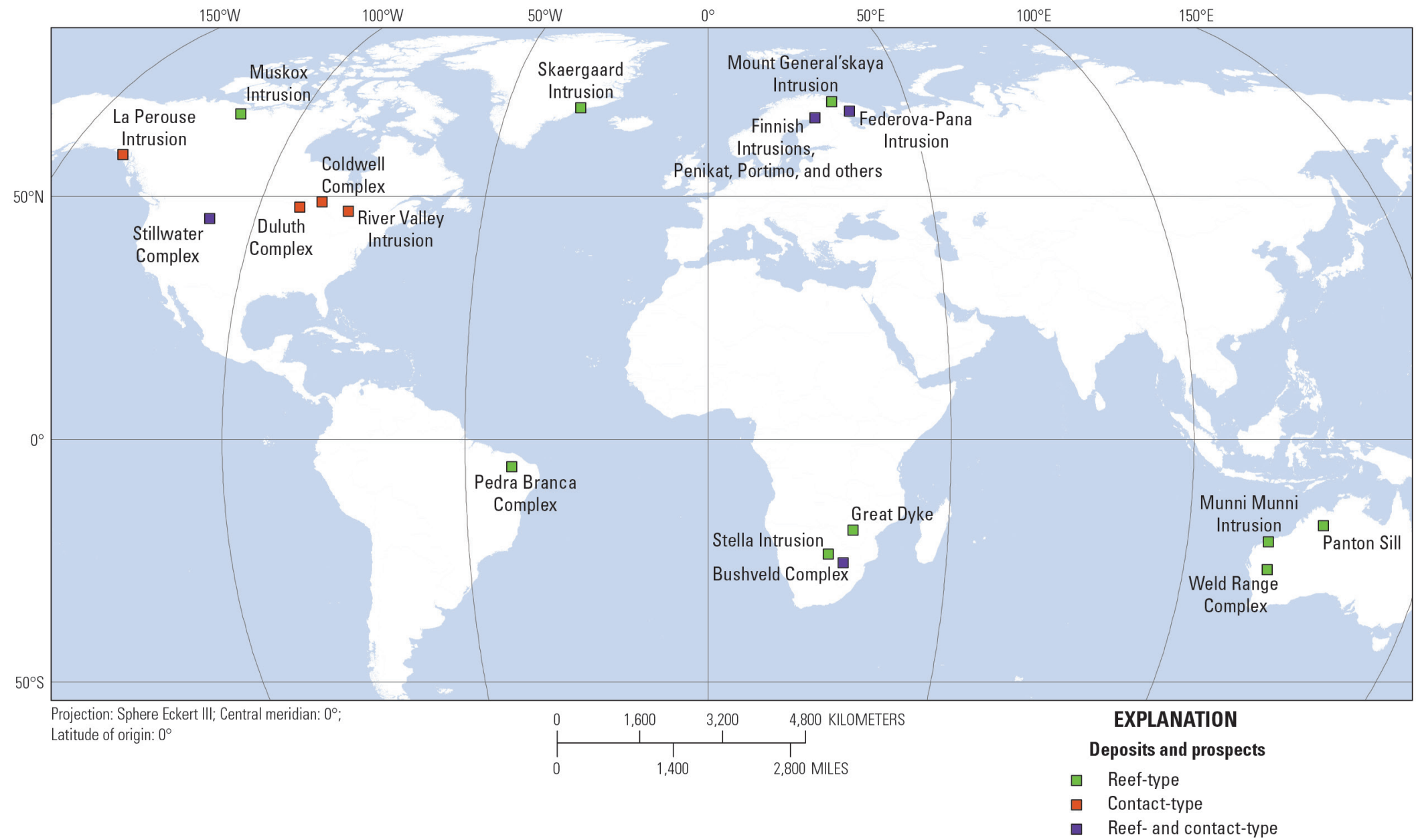

Figure 2. Map showing the location of intrusions hosting reef-type platinum-group elements (PGE) and contact-type Cu-Ni-PGE deposits. 


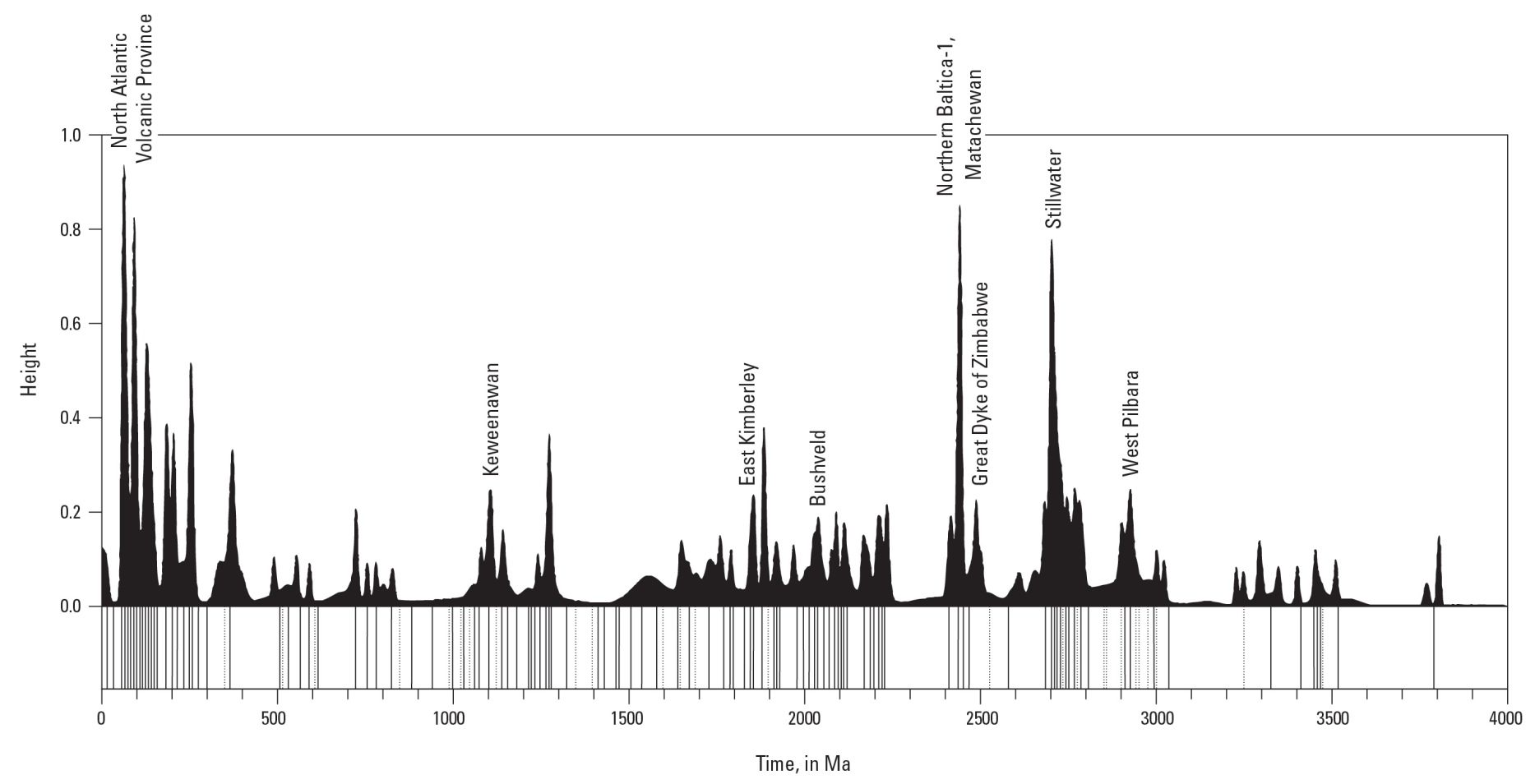

Figure 3. Chart showing the occurrence of large igneous provinces and superplume events with time. The upper curve shows a time series of superplume events versus time derived from adding Gaussians defined by ages and age errors of individual superplume proxies; height of peak is related to events with high-precision ages (Abbot and Isley, 2002). The lower bar graph shows the starting time of pulses of well-established and probable plume-head mafic-magmatic events (Ernst and others, 2005). Events that have layered igneous intrusions with reef-type platinum-group elements (PGE) and contact-type Cu-Ni-PGE deposits are labeled. 


\section{EXPLANATION}

Troctolitic cumulates

Gabbroic cumulates

Gabbronoritic cumulates

Pyroxenitic cumulates

Olivine-bearing cumulates

Basal pyroxenitic cumulates

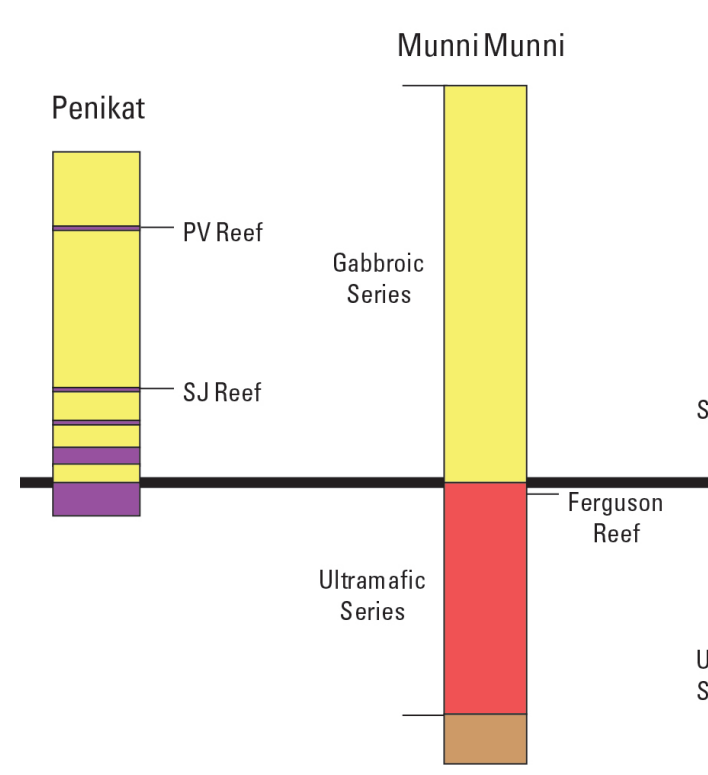

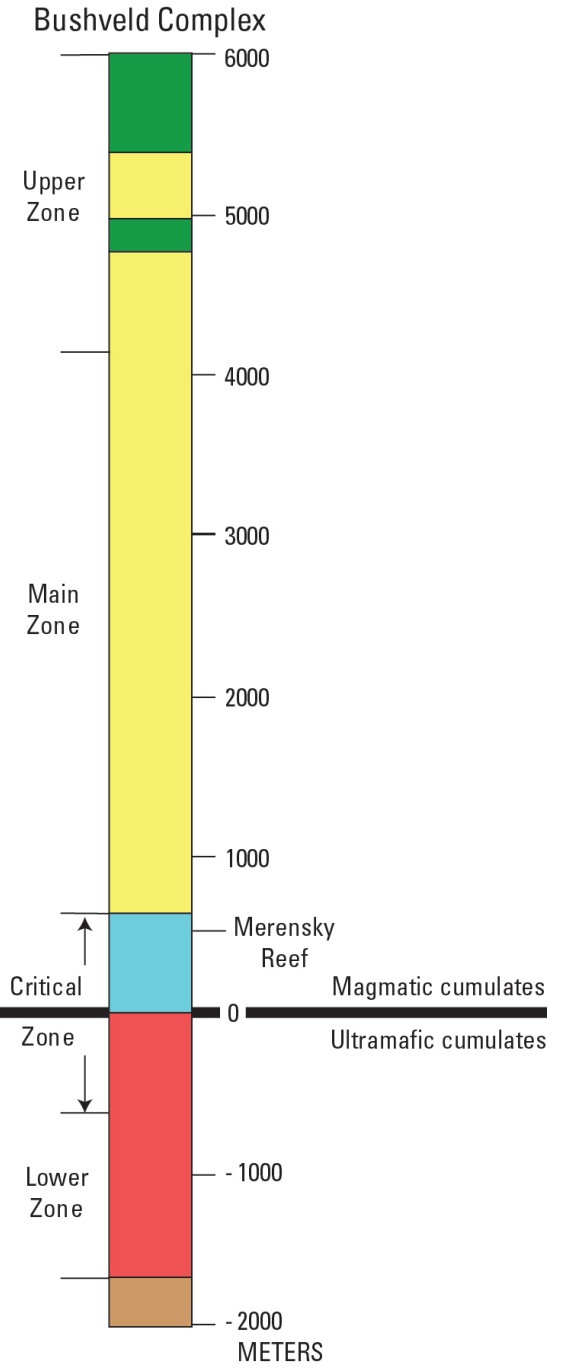

Figure 4. Columns that show the position of platinum-group elements reefs in the igneous stratigraphy of the Penikat, Munni Munni, Great Dyke, Stillwater, and Bushveld layered intrusions. 


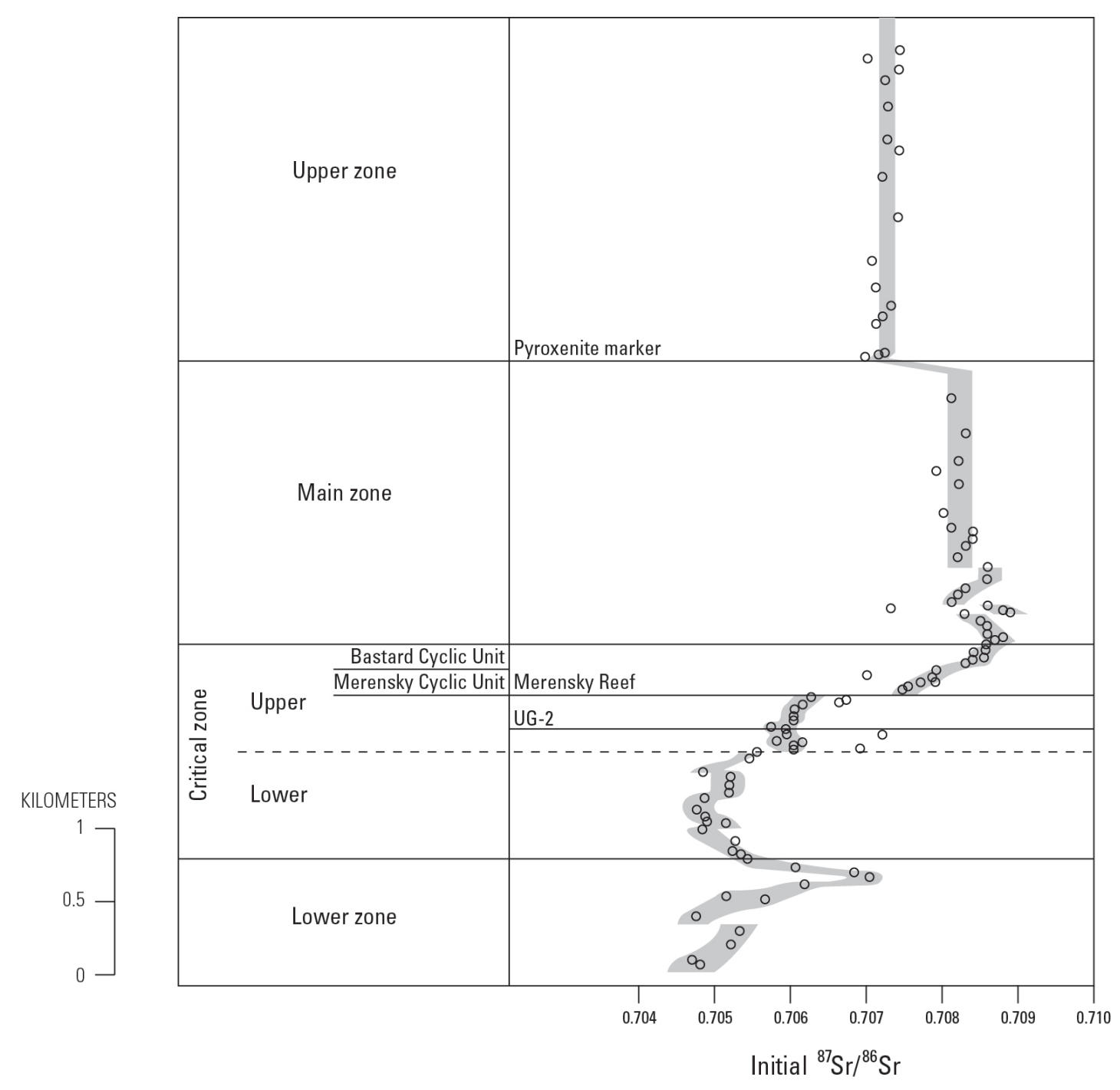

Figure 5. Stratigraphic variation of $\mathrm{Sr}$ isotope ratios in the Rustenburg Layered Series of the Bushveld Complex. Modified from (Kruger, 2005). 


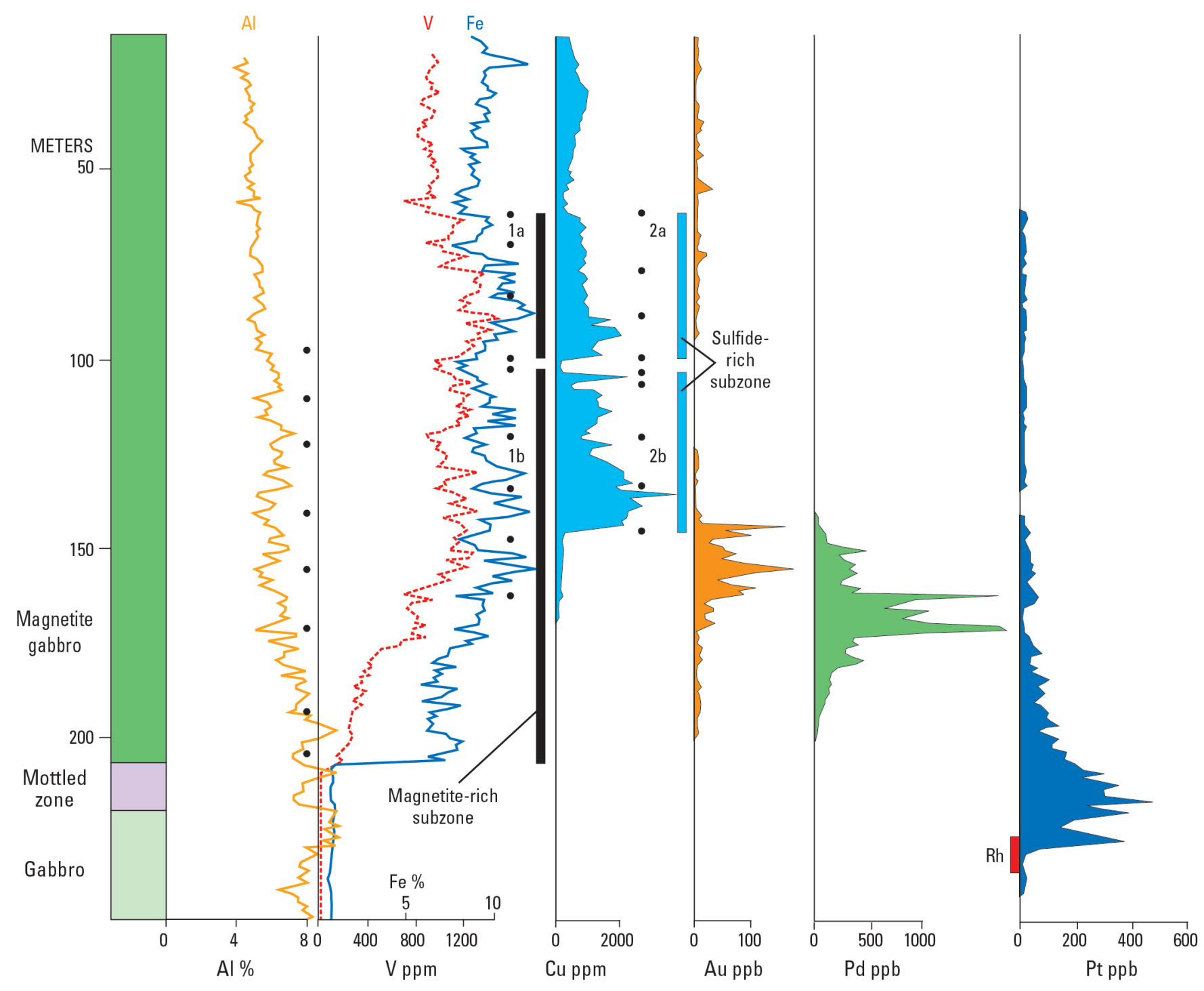

Figure 6. Stratigraphic variations in whole-rock $\mathrm{Al}, \mathrm{V}, \mathrm{Fe}, \mathrm{Cu}, \mathrm{Au}, \mathrm{Pd}$, and Pt contents in bore hole PA1 through the Precious Metals zone, Rincón del Tigre Complex, Bolivia. Modified from Prendergast (2000). 


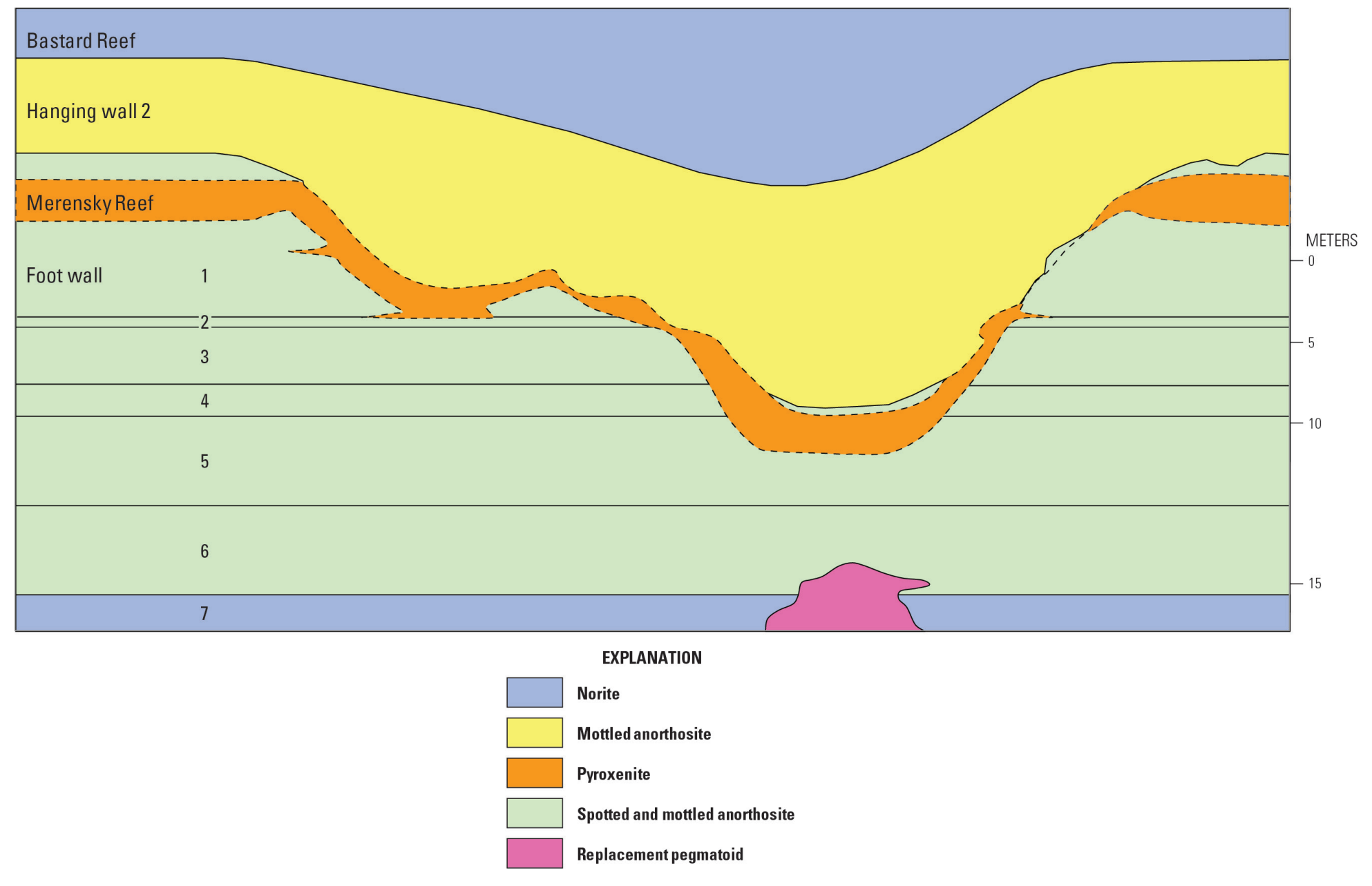

Figure 7. Section through two adjacent potholes illustrating the irregularity of the Merensky Reef, Bushveld Complex. Modified from Farquhar (1986). 
A

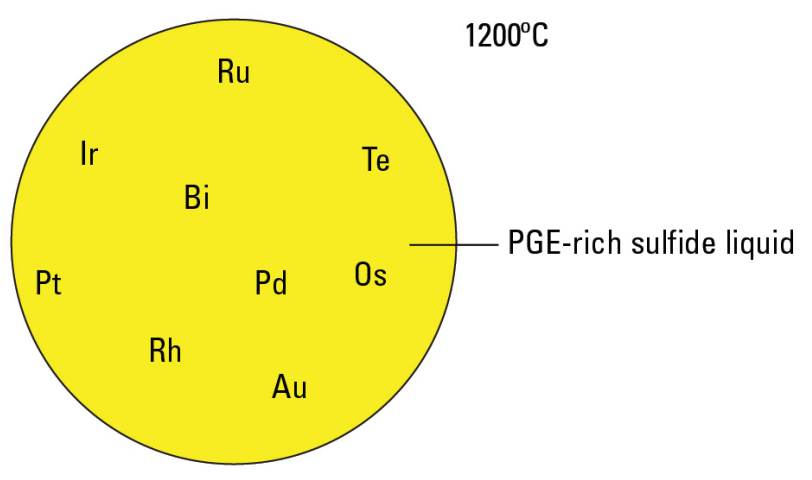

B

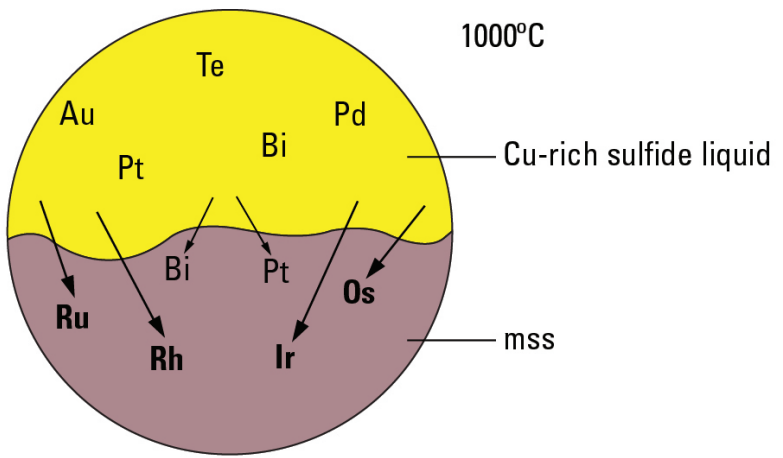

C

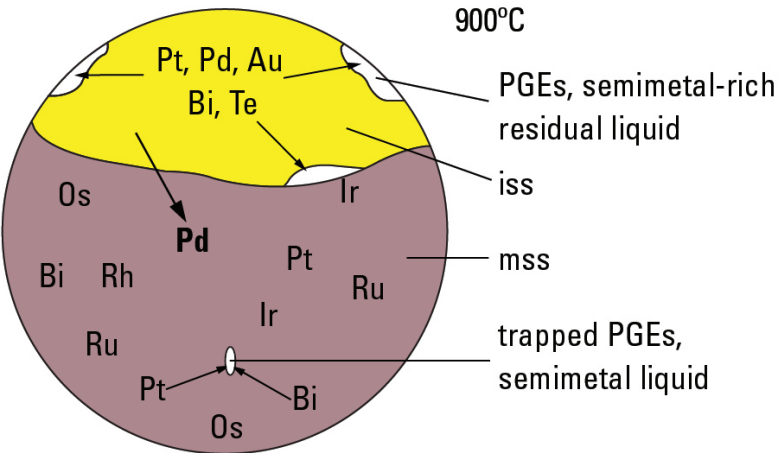

D

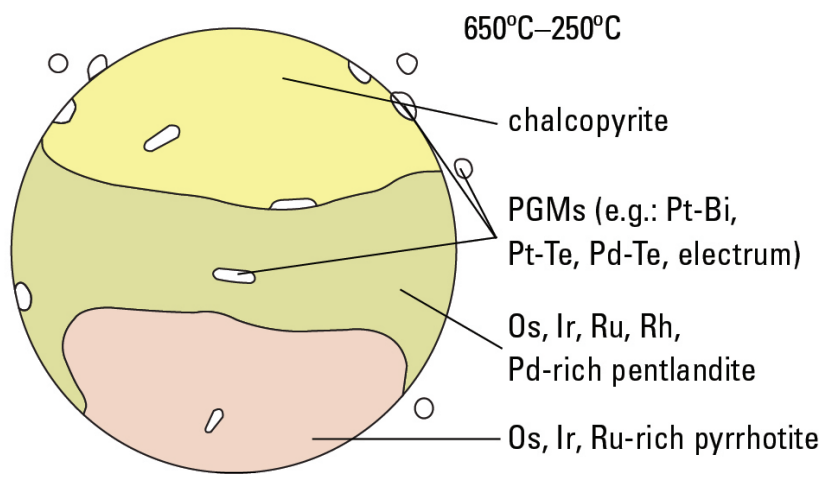

Figure 8. Schematic representation of a fractionating, platinum-group elements (PGE) enriched immiscible sulfide liquid droplet. Major partitioning behavior at each stage is emphasized by bold text. (A) Immiscible sulfide liquid. (B) Crystallization of monosulfide solid solution (mss). Os, Ir, $\mathrm{Ru}$, and $\mathrm{Rh}$ partition into the mss phase. (C) Crystallization of intermediate solid solution (iss) from 
residual sulfide liquid. Partitioning of $\mathrm{Pt}, \mathrm{Pd}$, and $\mathrm{Au}$ into semimetal-rich melt. Some $\mathrm{Pd}$ partitions into mss. (D) Recrystallization of mss to pyrrhotite and pentlandite. $\mathrm{Rh}$ and $\mathrm{Pd}$ are in solid solution in pentlandite. Crystallization of discrete platinum minerals from iss and from the residual semimetal liquid. Modified from Holwell and McDonald (2010). PGM, platinum-group minerals.
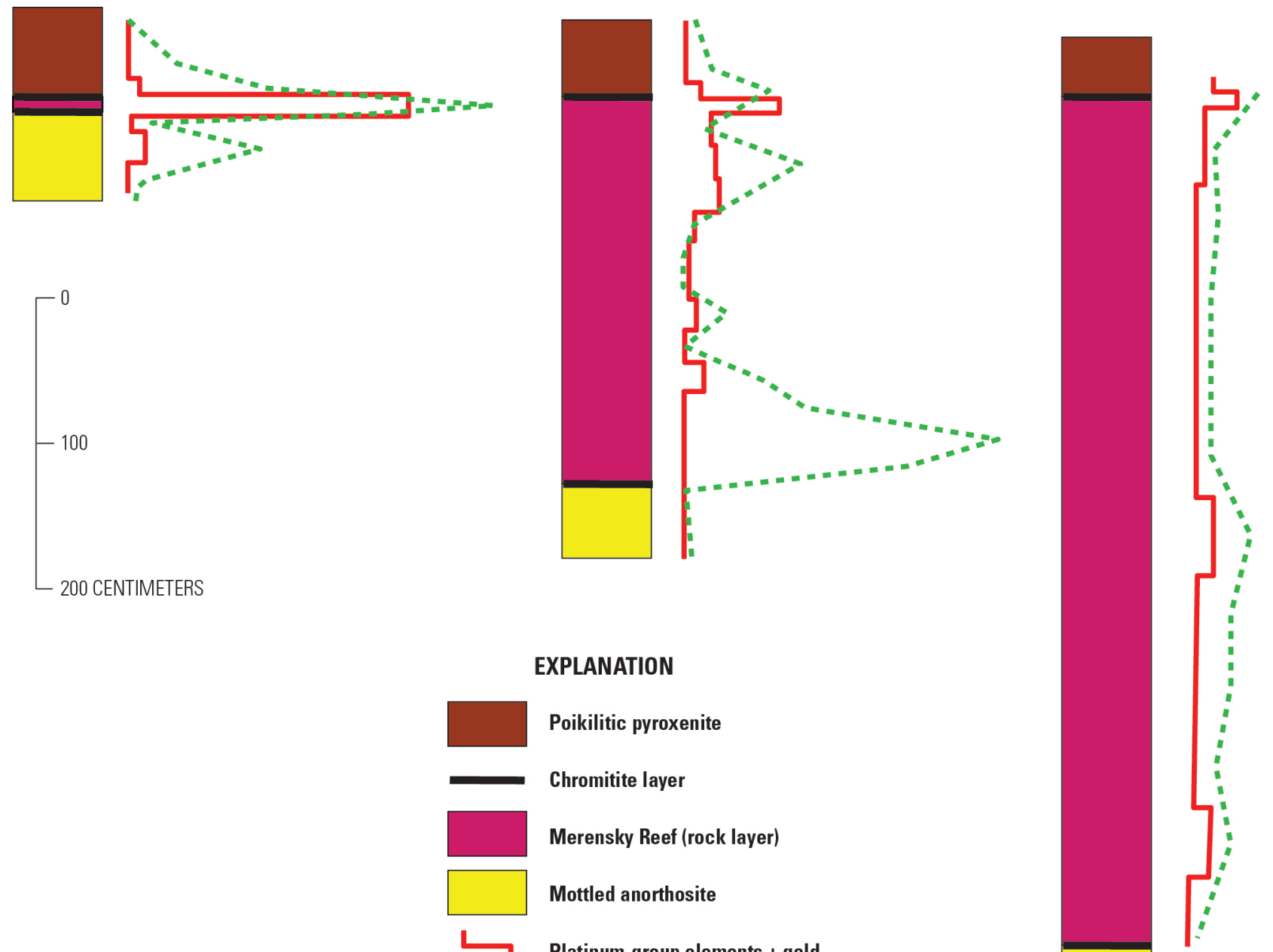

\section{EXPLANATION}
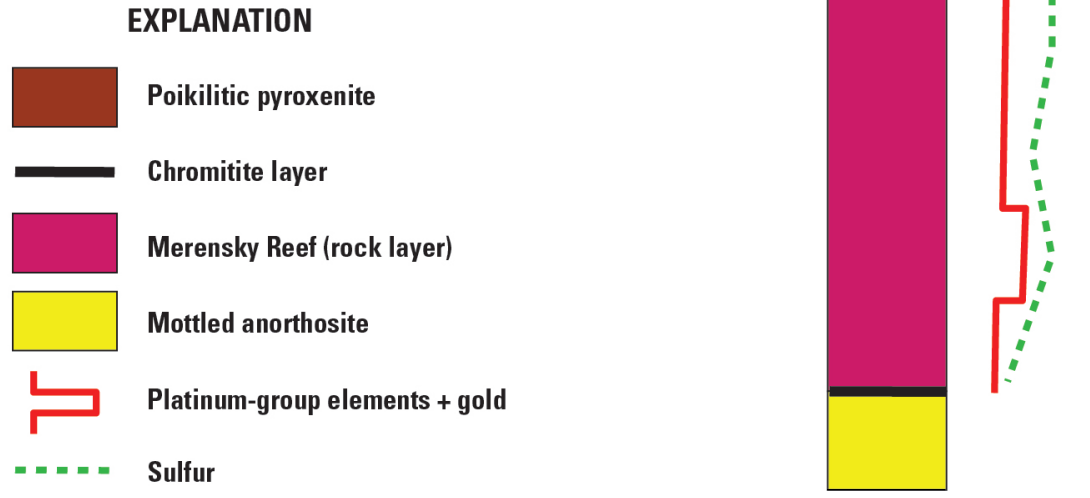

Figure 9. Variation in vertical value distribution for differing thicknesses of Merensky Reef, Amandelbult section of Rustenburg Platinum Mines. Modified from Viljoen and others (1986). 


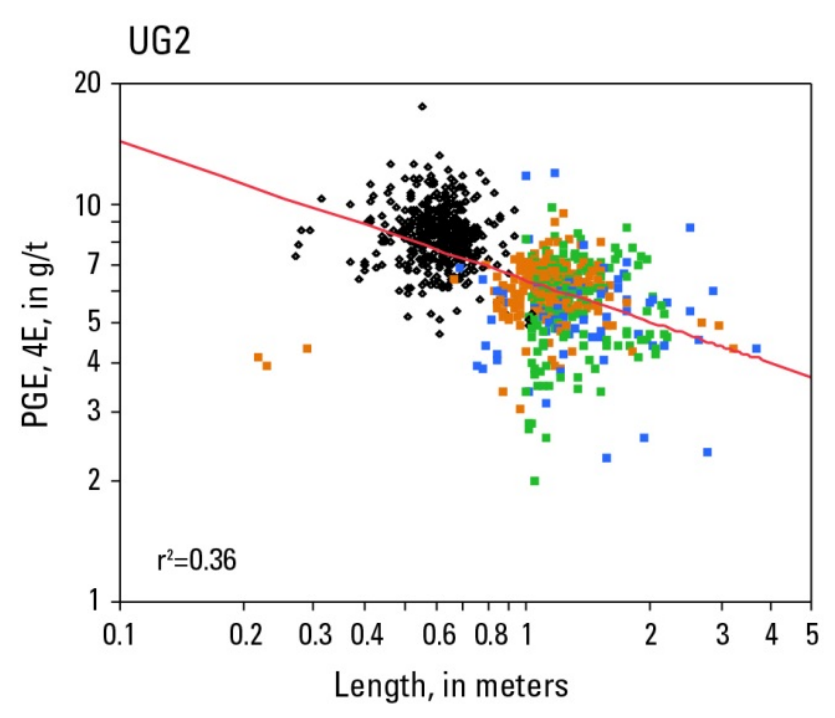

\section{EXPLANATION}

\section{Area}

- Ga-Pasha

- Mphahlele

- Ruighoek

- Tuschenkomst

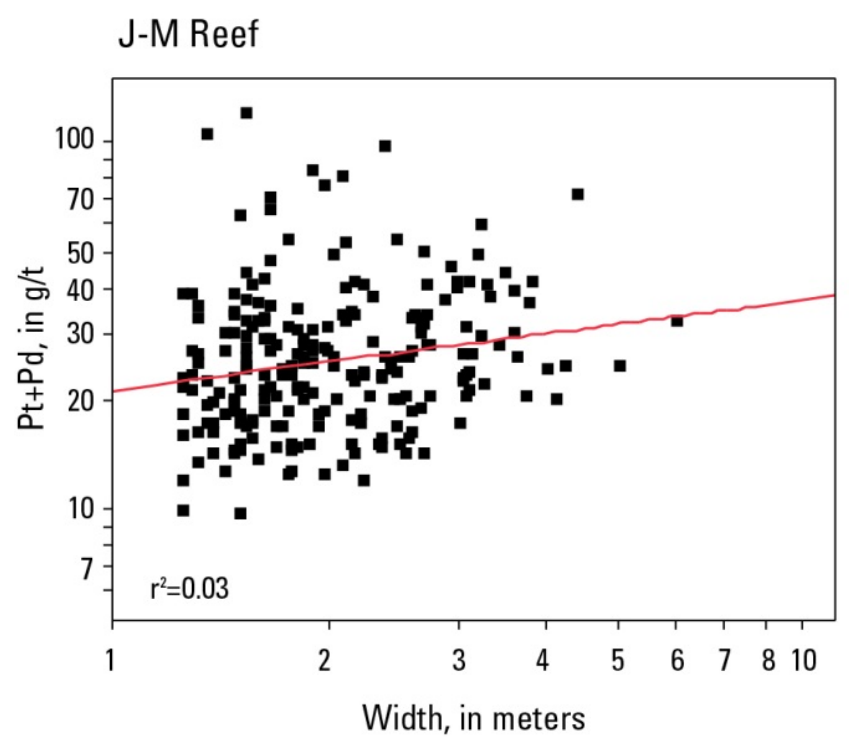

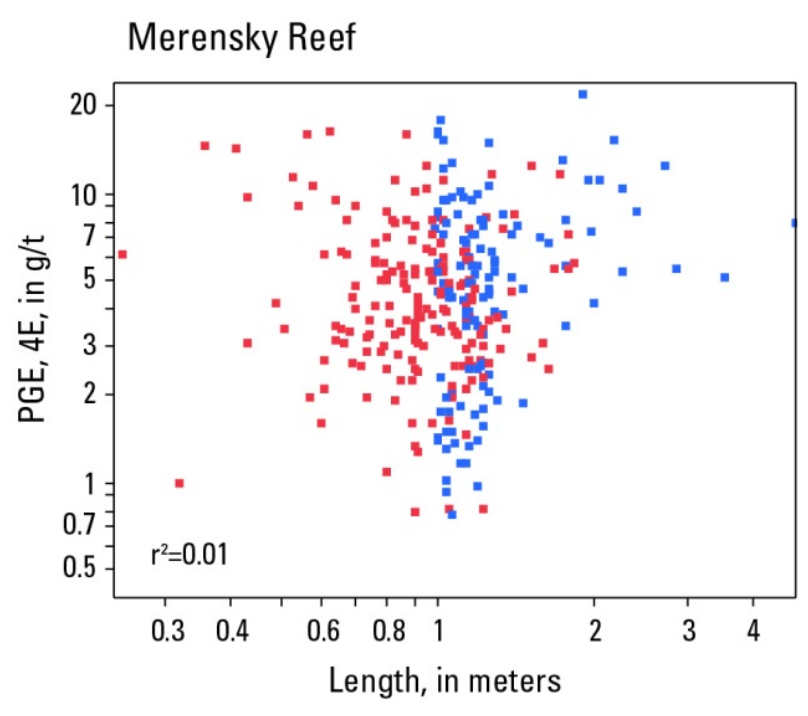

EXPLANATION

Area

- Ga-Pasha

- WBJV

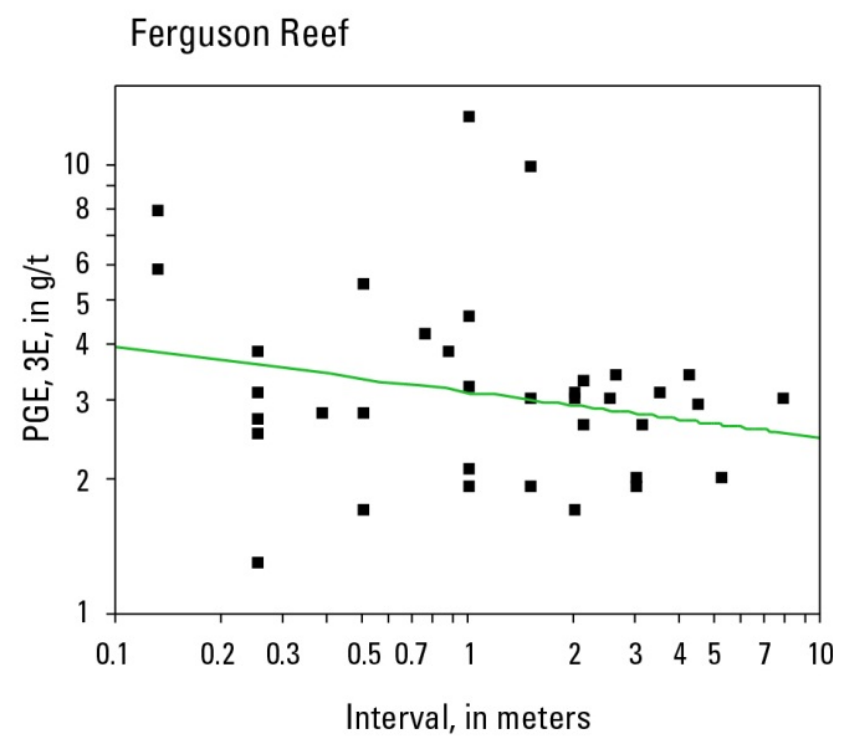

Figure 10. Bivariate plots of the combined grade of platinum, palladium, rhodium, and gold (4E) versus drill hole intercept for the UG2 chromitite and Merensky Reef, Bushveld Complex, the J-M Reef, Stillwater Complex, and the Ferguson Reef, Munni Munni Intrusion. Data are derived from company annual reports and presentations. PGE, platinum-group elements. 


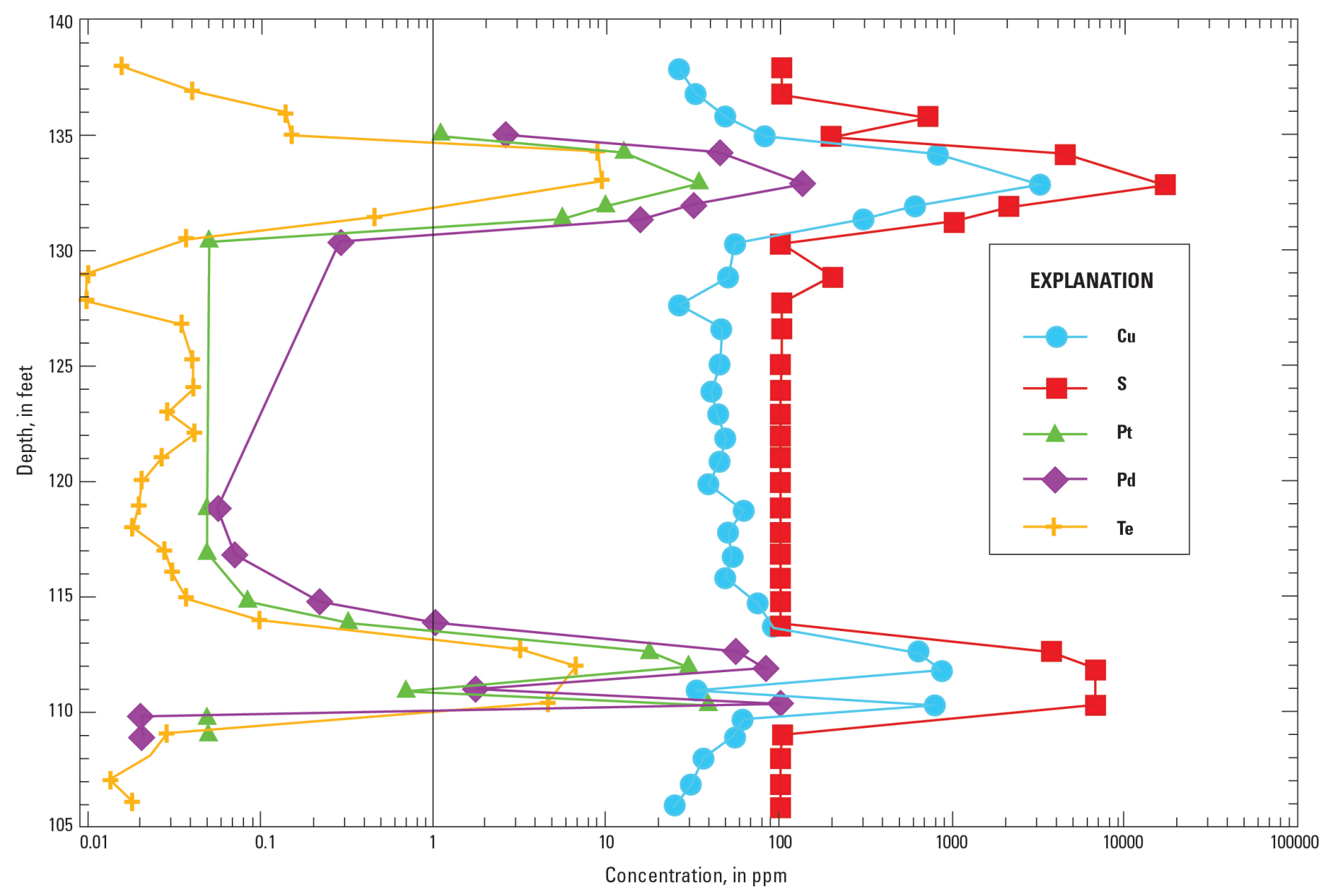

Figure 11. Profile through the J-M Reef, DDH701, 3800W stope, Stillwater Mine (Zientek and others, 1990).

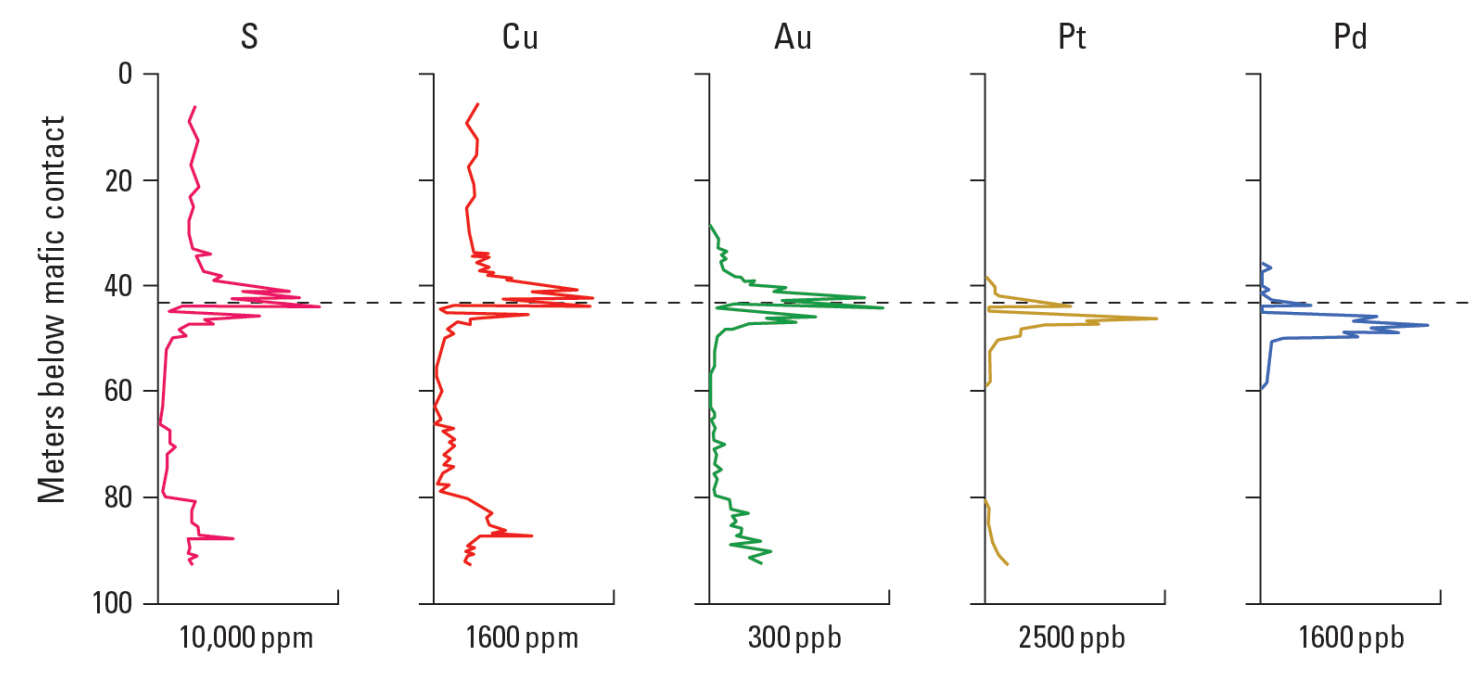

Figure 12. Vertical variation of elements through the Main Sulphide Zone in the Darwendale Subchamber of the Great Dyke, modified from Naldrett and Wilson (1990). 


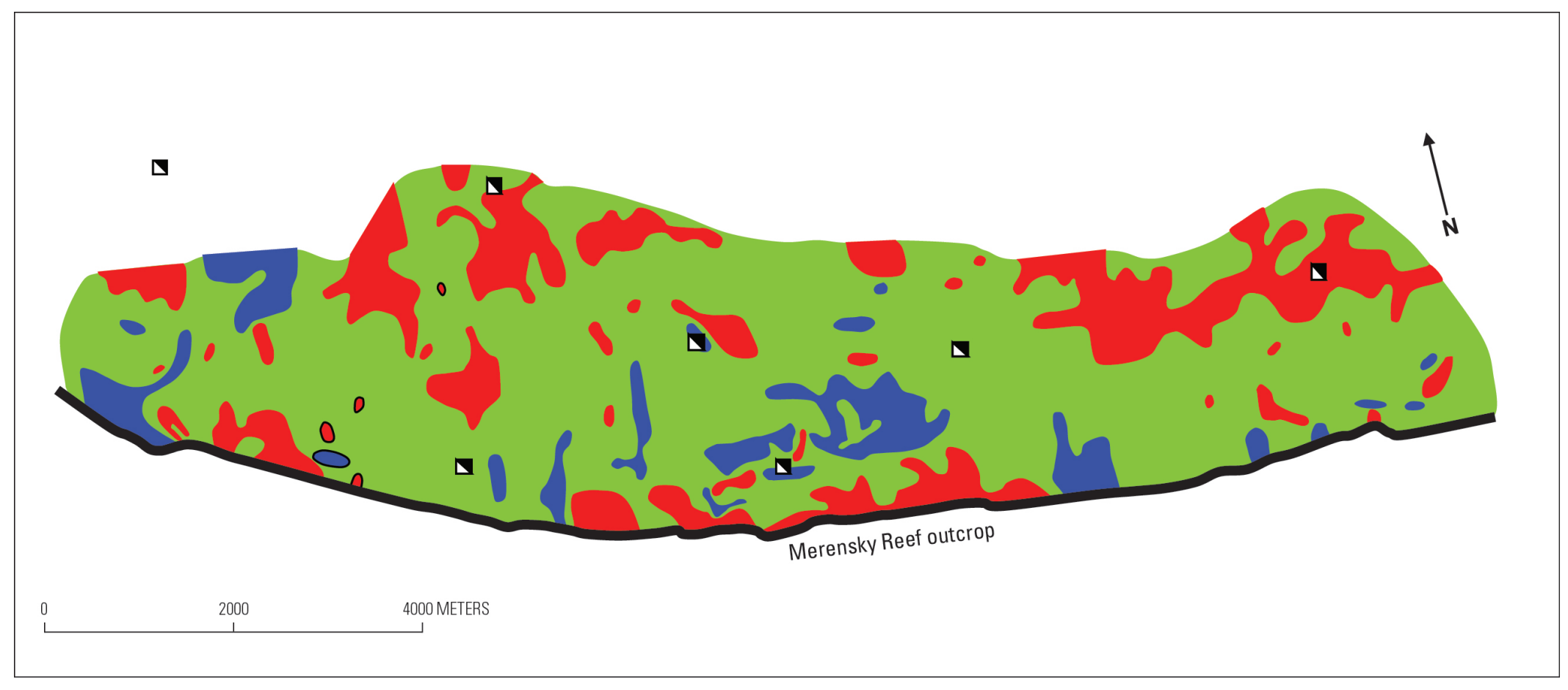

\section{EXPLANATION}

\section{Value of total PGE + Au}

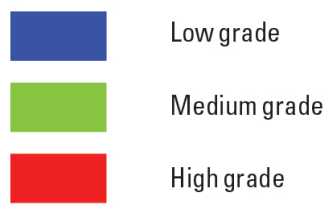

\ Mine shaft

Figure 13. Value contour map of the Merensky Reef, Rustenburg section of the Rustenburg Platinum Mines. Modified from Viljoen and Hieber (1986). PGE, platinum-group elements. 


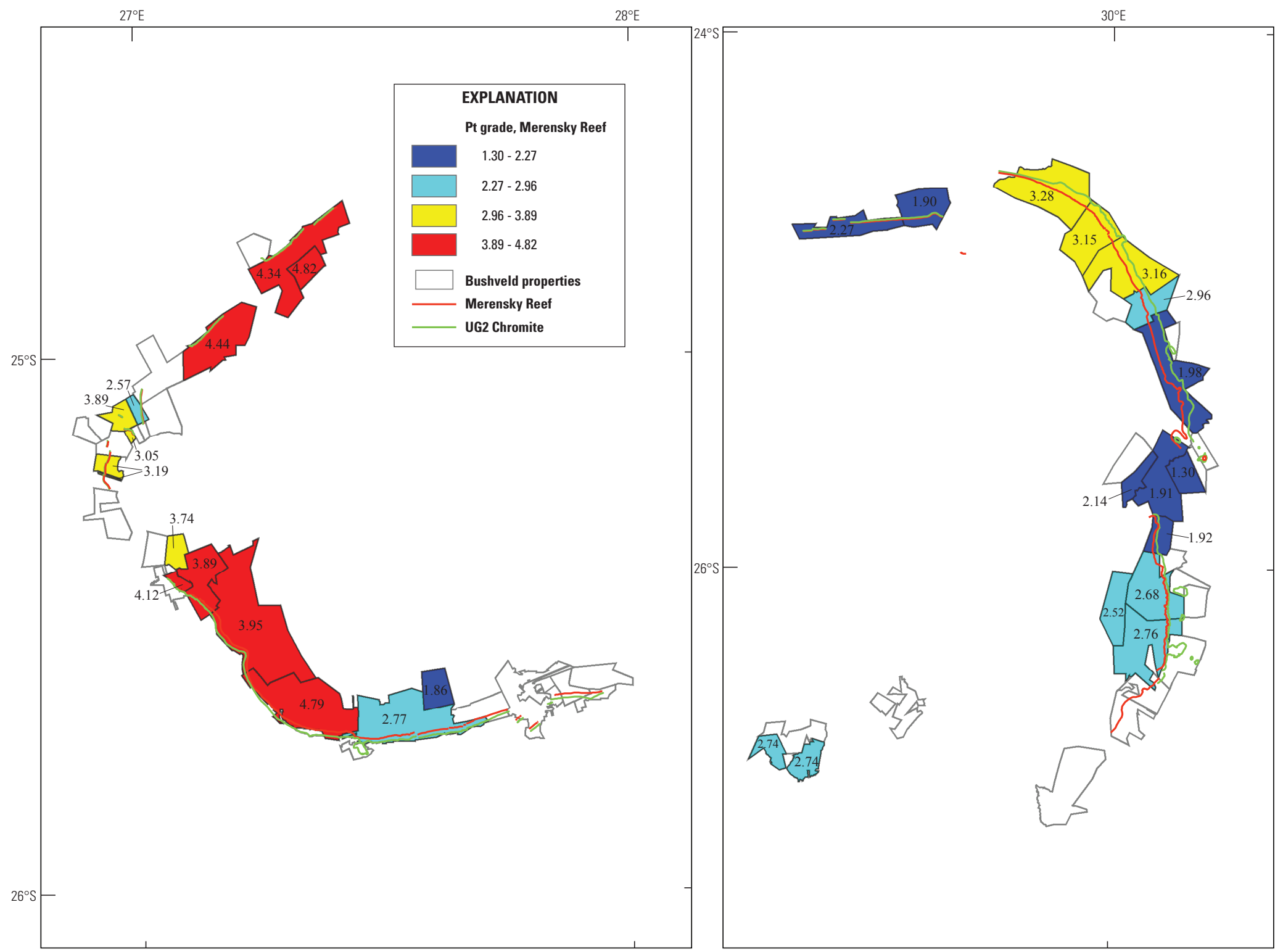

Figure 14. Map showing the outcrop trace of the Merensky Reef and its average platinum grade on mining properties in the Bushveld Complex. Data are derived from company annual reports and presentations and are current as of 2006. 


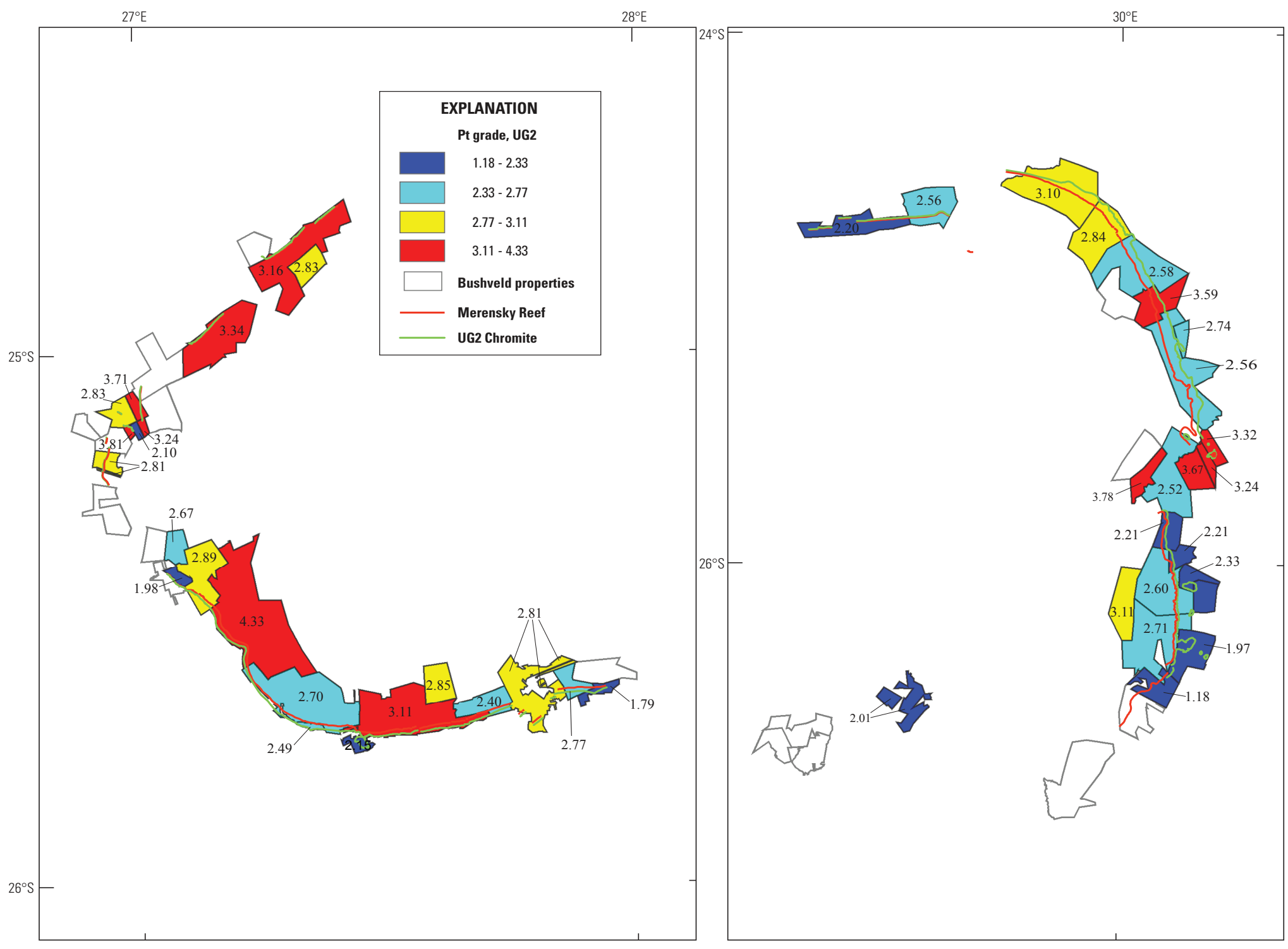

Figure 15. Map showing the outcrop trace of the UG2 chromitite and its average platinum grade on mining properties in the Bushveld Complex. Data are derived from company annual reports and presentations and are current as of 2006. 


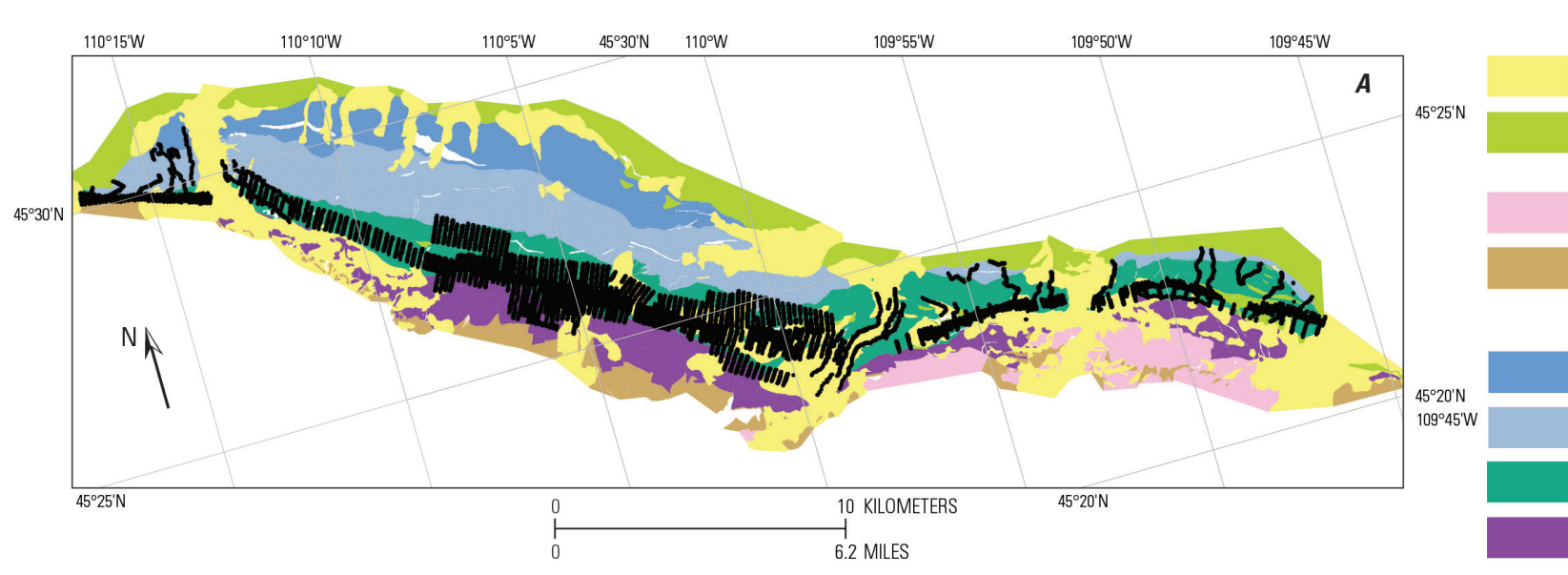

EXPLANATION

Unconsolidated deposits

Phanerozoic sedimentary rocks

\section{Archean quartz monzonite}

Older Archean rocks

Stillwater Complex

Upper Banded series

Middle Banded series

Lower Banded series

Ultramafic and Basal

series

- Sample locations

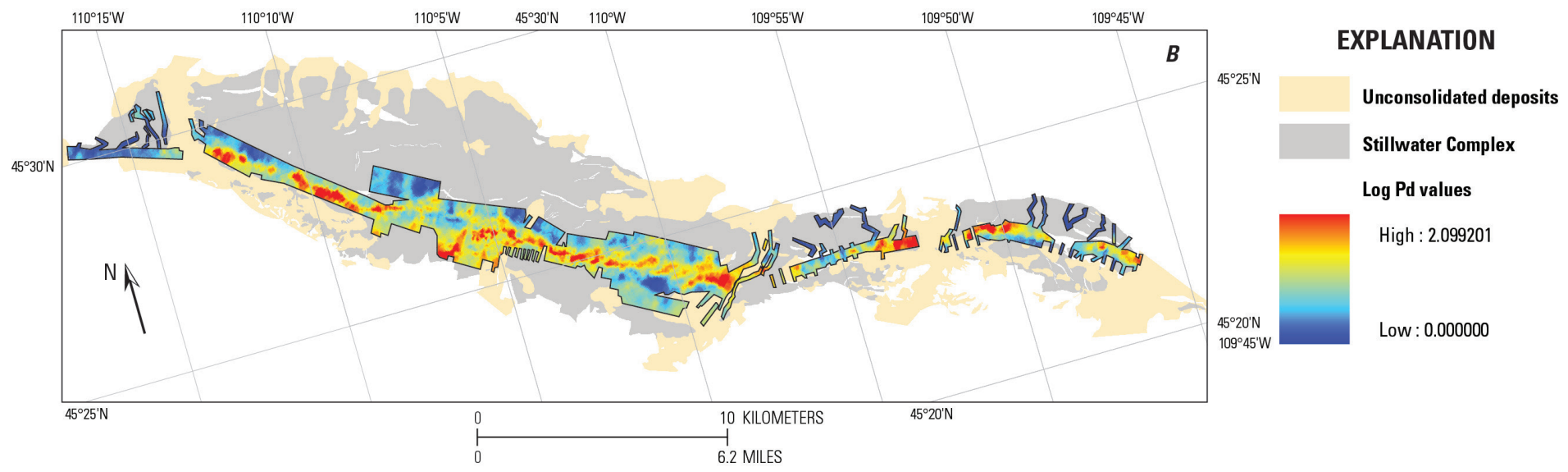

Figure 16. Maps showing the distribution and results of soil and talus fines geochemistry surveys in relation to the geology of the Stillwater Complex. (A) Location of talus and soil samples on map showing series level subdivisions of the Stillwater Complex. (B) Surface of log palladium values generated from sample data shown relative to the Stillwater Complex and unconsolidated deposits (Zientek and others, 2005). 

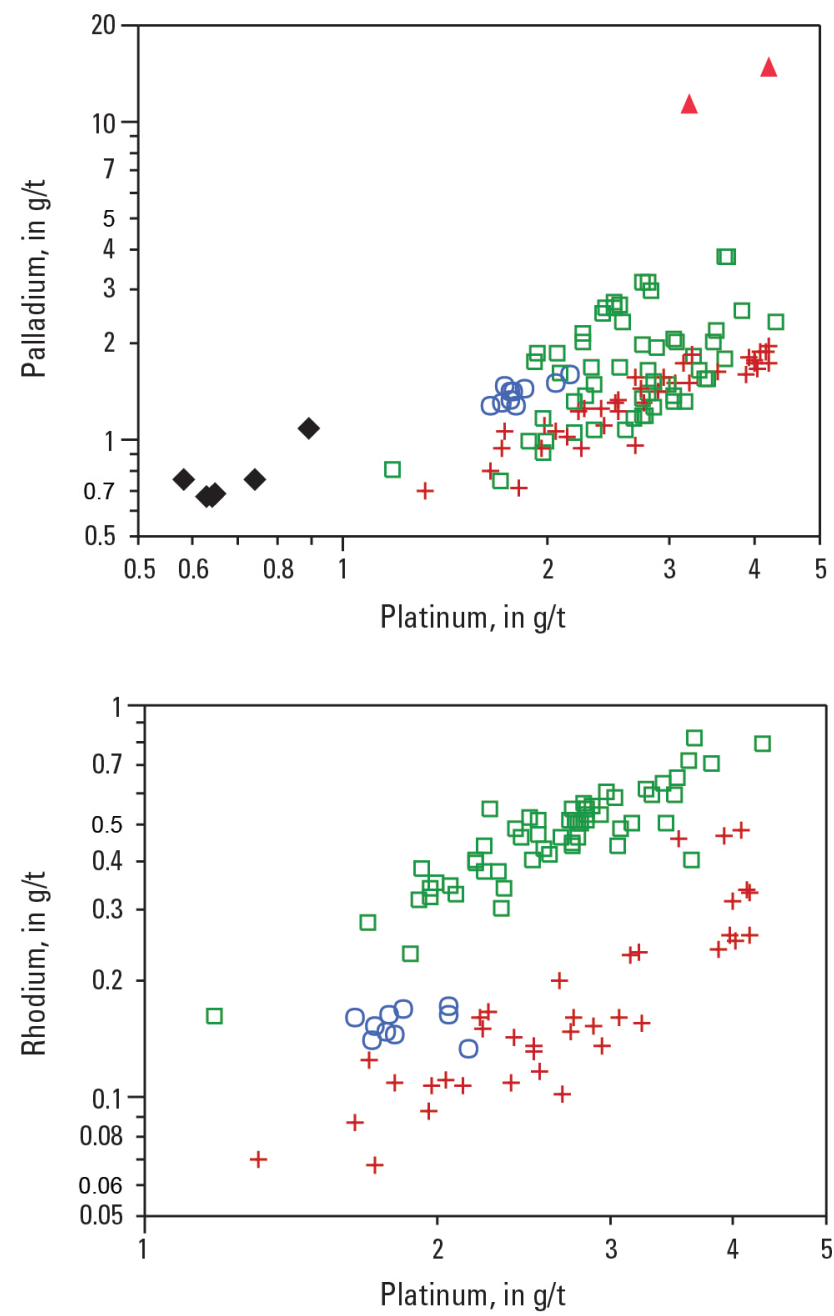

EXPLANATION

$\Delta$ J-M Reef(Stillwater)

- Main Reef Package (Stella)

O Main sulfide zone (Great Dyke)

+ Merensky Reef (Bushveld)

$\checkmark$ UG2 chromitite (Bushveld)

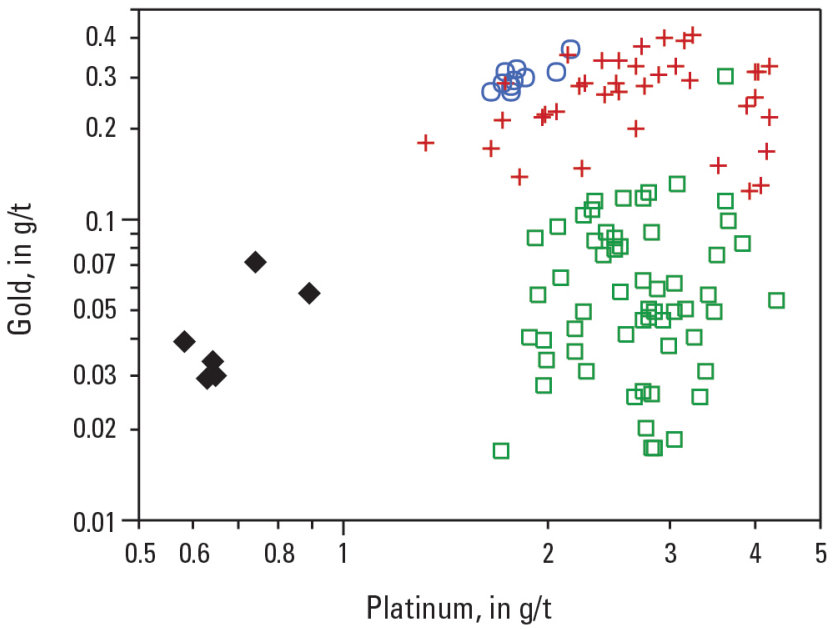

Figure 17. Bivariate plots of the average grade of palladium, rhodium, and gold versus average platinum grade for mines and mineral properties on the Stillwater, Stella, and Bushveld layered igneous intrusions. Data are derived from company annual reports and presentations and are current as of 2009. 


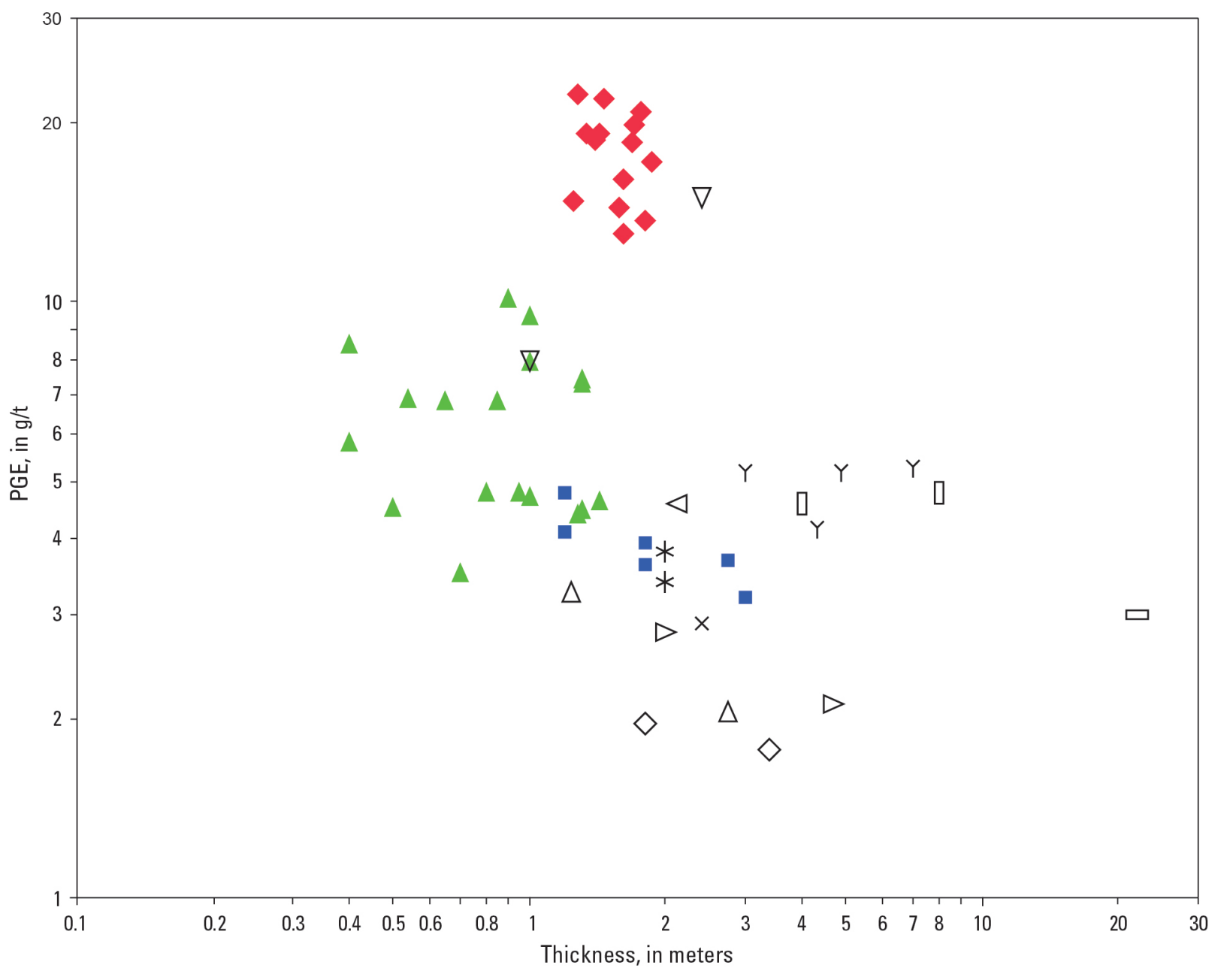

\section{EXPLANATION}

\begin{tabular}{|c|c|}
\hline \multicolumn{2}{|r|}{ Deposit and intrusion name } \\
\hline 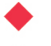 & J-M Reef, Stillwater Complex \\
\hline$*$ & LM Reef, Stella Intrusion \\
\hline$\square$ & Main reef package, Stella Intrusion \\
\hline$x$ & Main sulfide layer, Munni Munni \\
\hline $\mathbf{\square}$ & Main sulphide zone, Great Dyke \\
\hline$\Delta$ & Merensky Reef, Bushveld Complex \\
\hline$\triangleleft$ & Northern Reef, Pana \\
\hline$\triangleright$ & $\begin{array}{l}\text { Platinova Reef - Pd5 level, Skaergaard } \\
\text { Intrusion }\end{array}$ \\
\hline Y & $\begin{array}{l}\text { Sïka-Kämä (SK) Reef, Narkaus intrusion, } \\
\text { Portimo Complex }\end{array}$ \\
\hline$\nabla$ & S-J Reef, Penikat \\
\hline$\diamond$ & Skipper Lake zone, Coldwell Complex \\
\hline — & UM Reef, Stella Intrusion \\
\hline$\triangle$ & Upper pyroxenite unit, Molopo Farms Complex \\
\hline
\end{tabular}

Figure 18. Bivariate plot of the average platinum-group elements (PGE) grade versus mineralized layer thickness for PGE reef-type deposits. 


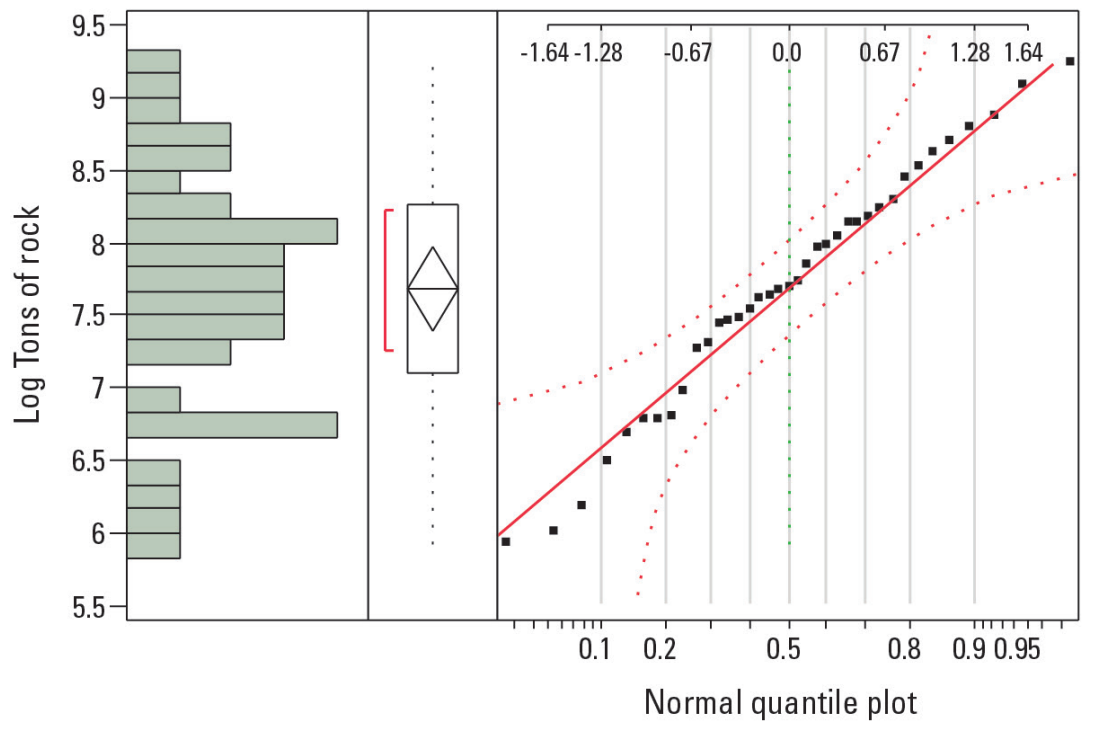

Figure 19. Histograms, box plots, and normal quantile plots illustrating distribution of tonnage of rock in contact-type deposits. 

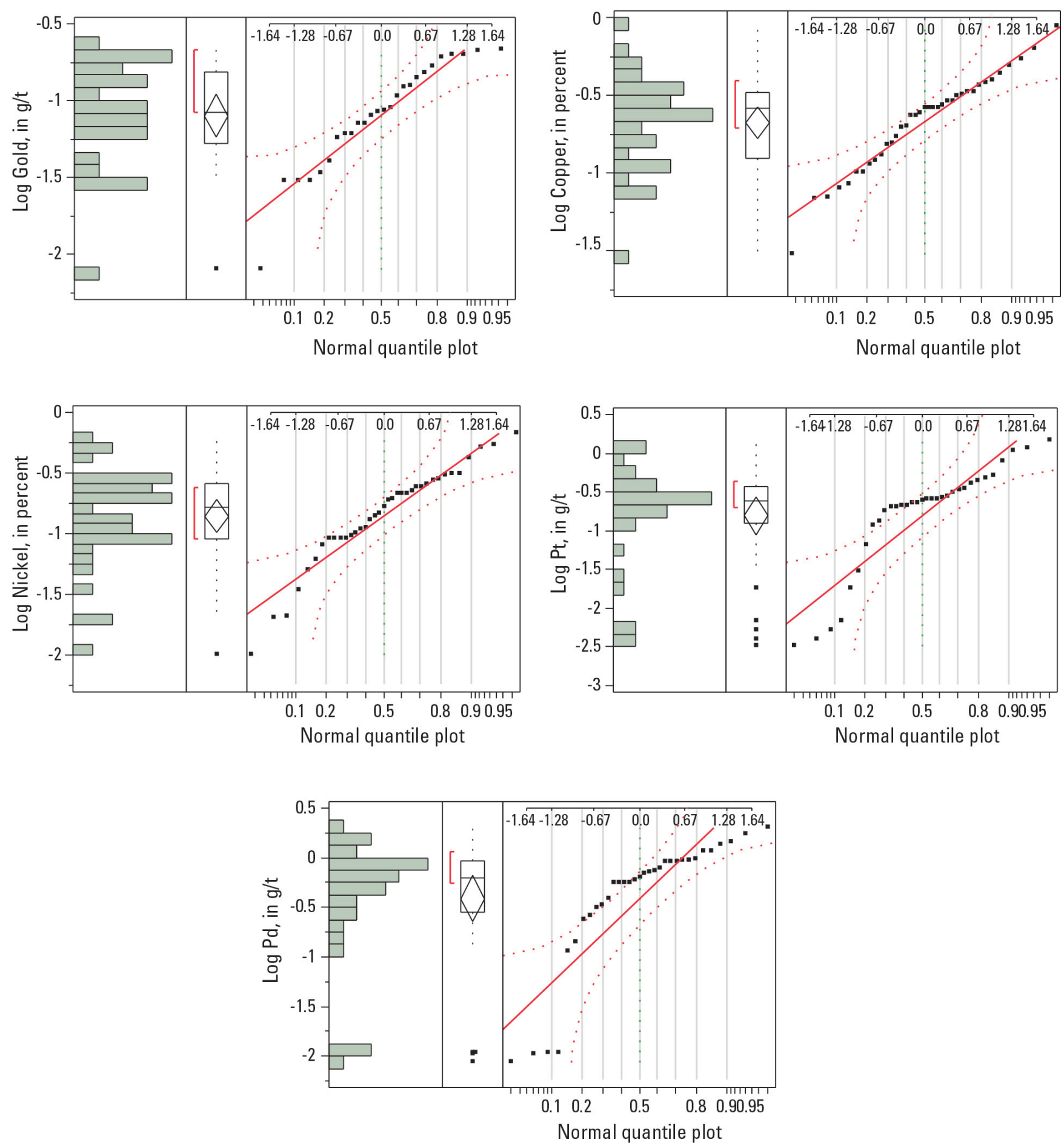

Figure 20. Histograms, box plots, and normal quantile plots illustrating distribution of copper, nickel, platinum, palladium, and gold in contact-type deposits. 

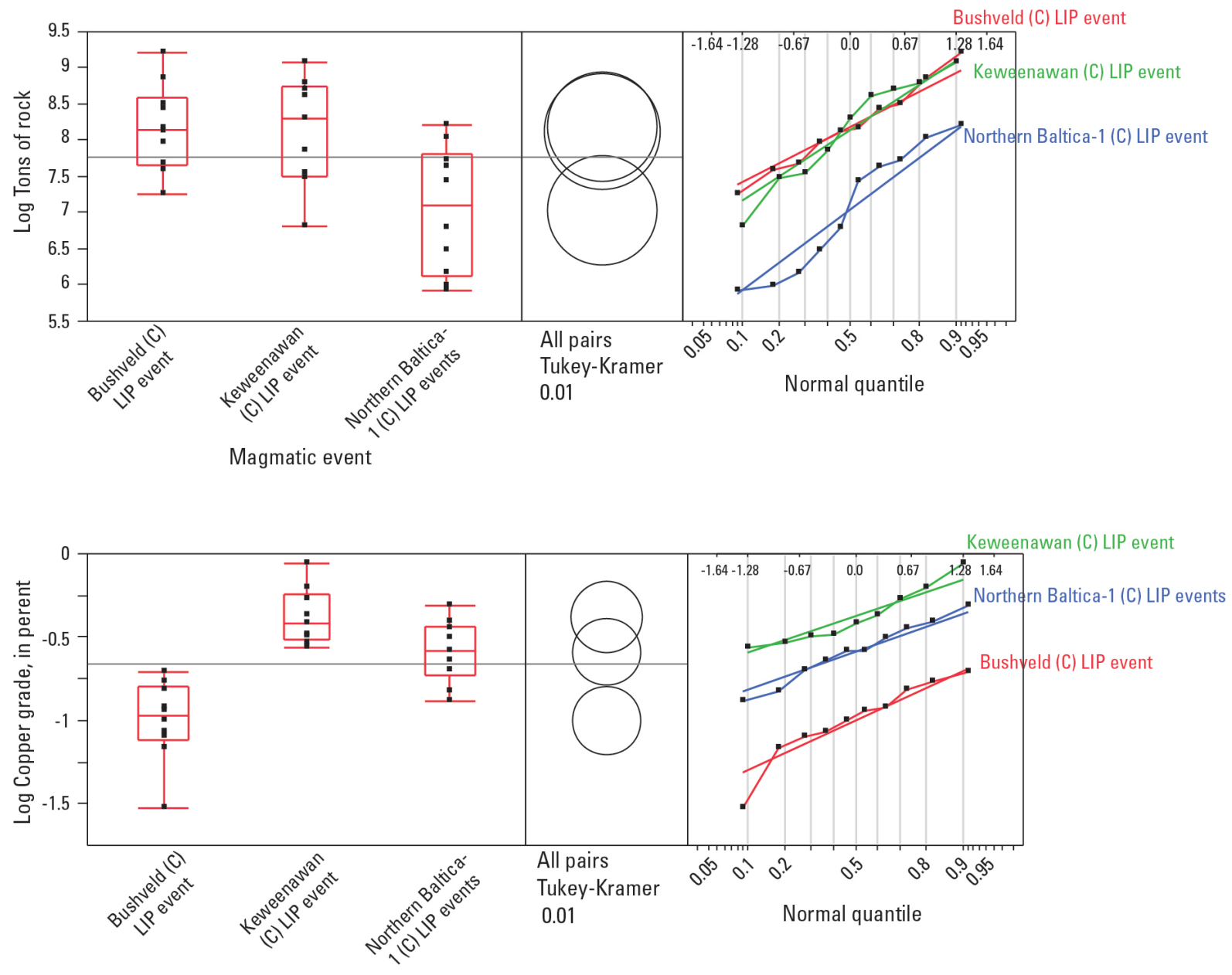

Magmatic event

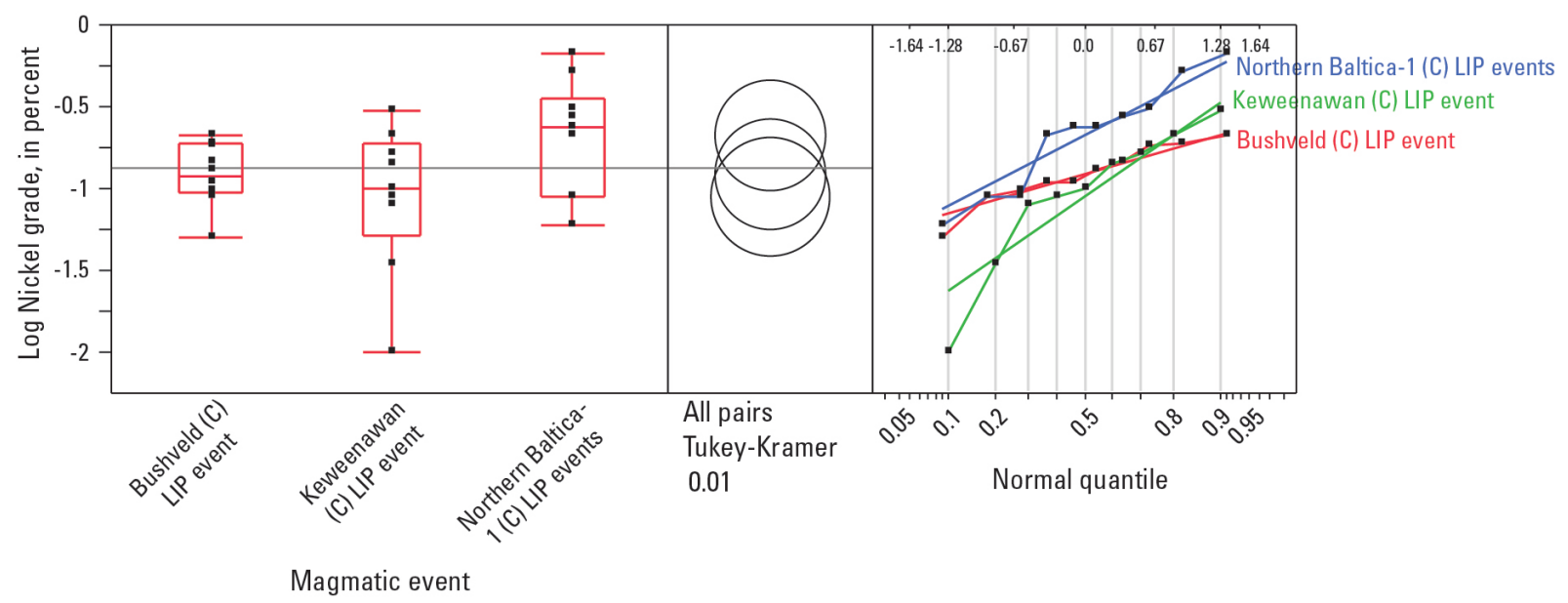

Figure 21. Box plots, comparison circles, and normal quantile plots comparing distribution of tonnage, copper grade, and nickel grade between deposits associated with the Bushveld, Keewenawan, and Baltica large igneous province (LIP) events. The letter (C) is a rating indicating that the event is possibly linked to a mantle plume head (Ernst and Buchan, 2001). 

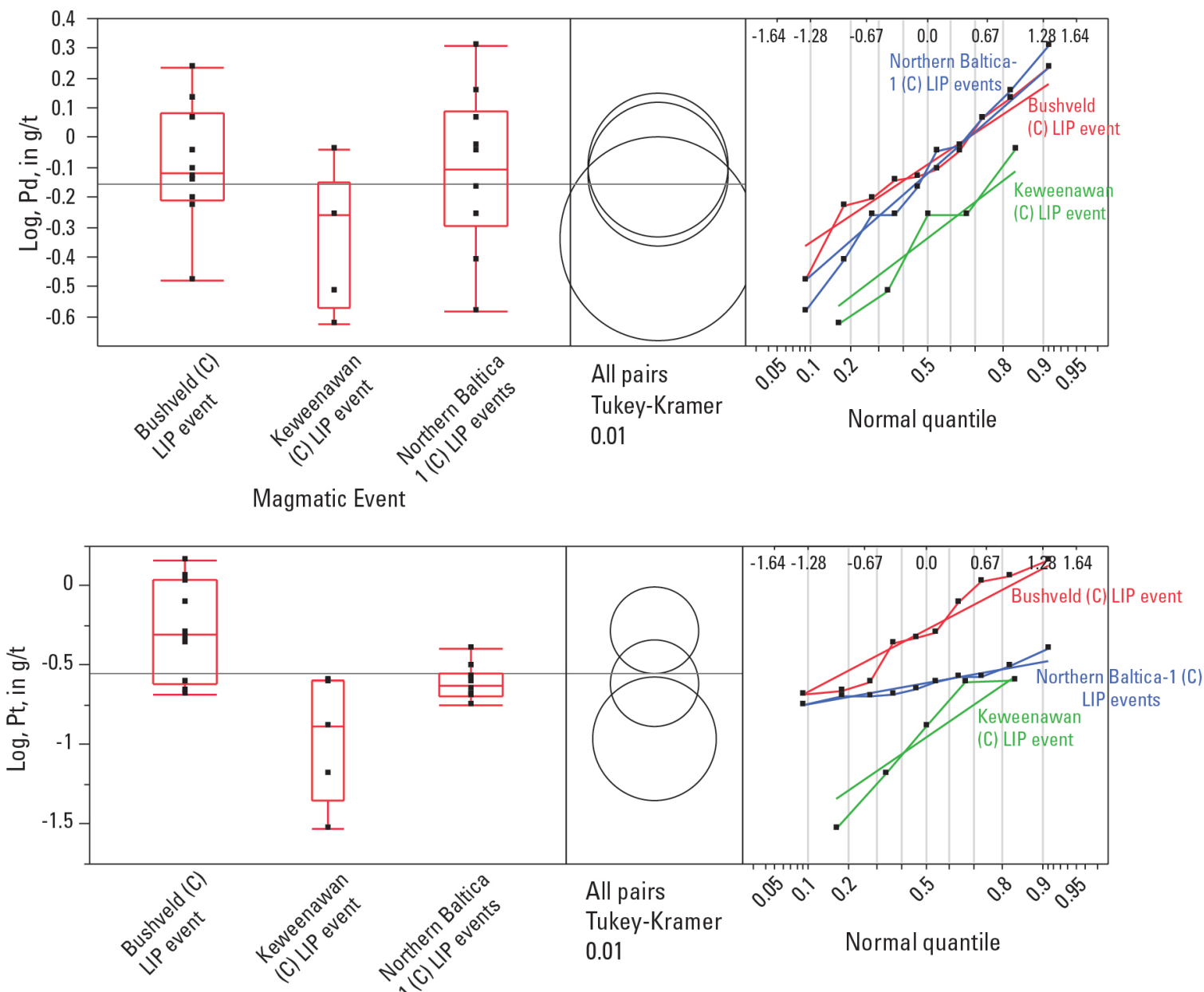

Magmatic Event

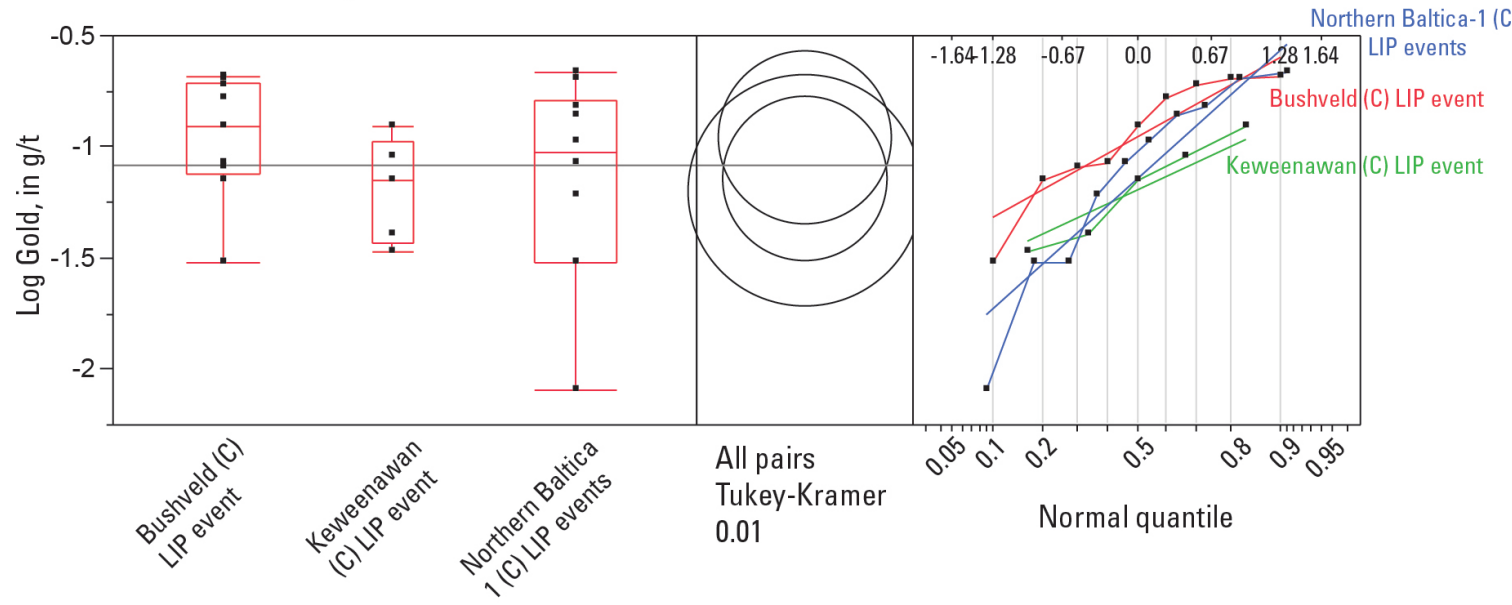

Magmatic event

Figure 22. Box plots, comparison circles, and normal quantile plots comparing distribution of palladium $(\mathrm{Pd})$, platinum $(\mathrm{Pt})$, and gold grade between deposits associated with the Bushveld, Keewenawan, and Baltica large igneous province (LIP) events. The letter (C) is a rating indicating that the event is possibly linked to a mantle plume head (Ernst and Buchan, 2001). 


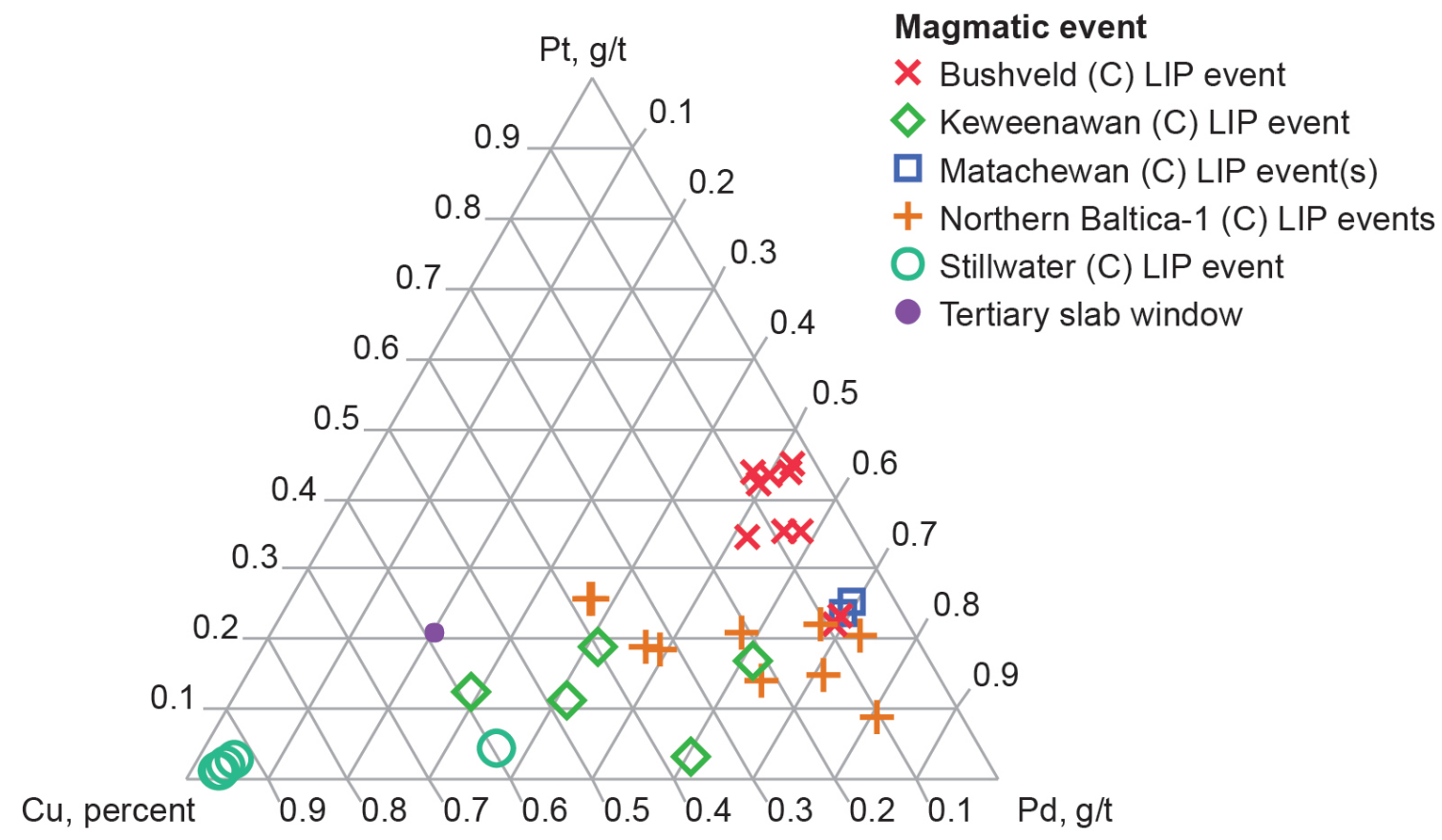

Figure 23. Ternary plot showing the proportion of copper, platinum, and palladium in contact-type deposits. LIP, large igneous province. The letter (C) is a rating indicating that the event is possibly linked to a mantle plume head (Ernst and Buchan, 2001).

Table 1. The platinum group elements, their atomic numbers, chemical symbols, and value.

\begin{tabular}{lccc}
\hline \multicolumn{1}{c}{ Element } & Atomic number & Chemical symbol & Price, U.S. \$ per oz \\
\hline Platinum & 78 & $\mathrm{Pt}$ & $1,820.78$ \\
Palladium & 46 & $\mathrm{Pd}$ & 739.18 \\
Rhodium & 45 & $\mathrm{Rh}$ & $1,863.36$ \\
Ruthenium & 44 & $\mathrm{Ru}$ & 169.38 \\
Iridium & 77 & $\mathrm{Ir}$ & $1,068.57$ \\
Osmium & 76 & $\mathrm{Os}$ & 380.00 \\
\hline
\end{tabular}


Table 2. Tonnage and grade characteristics of reserves and resources associated with reef-type platinum-group elements deposits. Past production is not included. Large igneous province (LIP) names and ratings from Ernst and Buchan (2001).

\begin{tabular}{|c|c|c|c|c|c|c|c|c|c|c|c|c|c|c|c|c|c|c|}
\hline Tormatic rom & IIP pating & $\begin{array}{c}\text { pproximate age } \\
\text { (Ma) }\end{array}$ & Denosit name & Intususion & Area & Cront & Date of estimate & Resource category & ingente & Ni percent & Cu, percent & if Pt,gtt & $\mathbf{P d}$, git & $\mathrm{Rh}, \mathrm{glt}$ & Au, glt & $\underset{\mathrm{Pt}+\mathrm{Pd}+\mathrm{Au},}{\mathrm{g} / \mathrm{t}}$ & "PGE" $\pm A u, g / t$ & References \\
\hline Busiveld (C) LIP event & $\mathrm{A}(\mathrm{ls})$ & 2054 & Merensky Footwall Reef & Bushveld Complex & BV-Western Limb & RSA & 2009 & Reserves and measurued, indicated, and inferred resources & $26,182.000$ & & & 0.6161 & 0.2828 & 0.0606 & 0.0505 & & 1.01 & D. Causey, written comm. 2009 \\
\hline Busiveld (C) LIP event & $\mathrm{A}(\mathrm{ls})$ & 2054 & Merenskly Reef & Bushveld Complex & & RSA & 1999 & Proven and probable reserves and infered resources & $4,987,800,000$ & & & 3.279572276 & 1.762486547 & & & & 5.042058824 & Cawthron (1999) \\
\hline Busiveld (C) LIP event & $\mathrm{A}(\mathrm{ls})$ & 2054 & Merensky Recf & Bushveld Complex & BV-Eastern and Western Limb & RSA & 2009 & Resserves and mcasurured, indicated, and infered resourres & $3,73,344,220$ & & & 2.906020937 & 1.428774501 & 0.203193246 & 0.2664378 & & 4.804426483 & D. Causcy, written comm, 2009 \\
\hline Busiveld (C) LIP event & $\mathrm{A}(\mathrm{ls})$ & 2054 & PGE Reefs (undifferentiated) & Bushveld Complex & BV-Westem Limb & RSA & 2009 & Reserves and measured, indicated, and inferred resources & $114,745,000$ & & & 3.188030038 & 1.541009335 & 0.425946319 & 0.119434734 & & 5.274420427 & D. Causey, written comm, 2009 \\
\hline Busiveld (C) LIP event & $\mathrm{A}(\mathrm{ls})$ & 2054 & Psendo Reef Harbhurgite & Bushveld Complex & BV-Western Limb & RSA & 2009 & Reserves and measured, indicated, and inferred resources & $19,554,000$ & & & 0.531 & 0.279 & 0.036 & 0.054 & & 0.9 & D. Cansey, written comm, 2009 \\
\hline Busiveld (C) LIP event & $\mathrm{A}(\mathrm{ls})$ & 2054 & Lower Psendo Reef & Bushveld Complex & BV-Western Limb & RSA & 2009 & Reserves and measurred, indicated, and inferred resources & $8,846,800$ & & & 1.519225311 & 0.712740496 & 0.209633251 & 0.072927456 & & 2.514526513 & D. Causey, written conm, 2009 \\
\hline Busineld (C) LIP event & $\mathrm{A}(\mathrm{l}) \mathrm{s}$ & 2054 & Upper Pseudo Reef & Bushveld Complex & BV-Westem Limb & RSA & 2009 & Reserves and measured, indicated, and inferred resources & $6,539,800$ & & & 2.118700244 & 1.036587849 & 0.170537053 & 0.138449323 & & 3.464274469 & D. Causey, written comm, 2009 \\
\hline Bushveld (C) LIP event & $A(15)$ & 2054 & Shecha's Ridgc & Bushveld Complex & BV-Fastern Limb & RSA & 2009 & Reserves and measurrod, indicated, and inferred resources & $775,000,000$ & & & 0.175301548 & 0.541148258 & & 0.045730839 & & 07621806645 & D. Causey, written comm, 2009 \\
\hline Busiveld (C) LIP event & $A(1 \mathrm{~s})$ & 2054 & UG2 & Bushveld Complex & & RSA & 1999 & Proven and probable reserves and inferred resources & $6,250,600,000$ & & & 2.84299648 & 2.322447829 & & & & 5.165444309 & Cauthron (1999) \\
\hline Busineld (C) LIP event & $\mathrm{A}(\mathrm{ls})$ & 2054 & UG2 & Bushveld Complex & BV-Eastern and Westem Limb & RSA & 2009 & Reserves and measurred, indicated, and inferred resources & $6,636,236,713$ & & & 2.701973524 & 1.834189128 & 0.496749709 & 0.059239758 & & 5.092152119 & D. Causey, witten comm, 2009 \\
\hline Bushveld (C) LIP event & $\Lambda(1 \mathrm{ls})$ & 2054 & 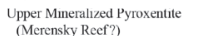 & Bushveld Complex & BV-Westem Limb & RSA & 2009 & Reserves and measurred, indicated, and inferred resources & $24,730,000$ & & & 2.546652337 & 1.212691589 & & 0.2676568666 & & 4.027000793 & D. Causey, written camm. 2009 \\
\hline Busiveld (C) LIP event & $\mathrm{A}(\mathrm{ls})$ & 2054 & $\begin{array}{l}\text { Mererkny keer? } \\
\text { Platref }\end{array}$ & Bushveld Complex & & RSA & 1999 & Proven and probable reserves and infered resources & $2,274,600,000$ & & & 2.199211905 & 2.220314693 & & & & 4.419526598 & Cauthron (1999) \\
\hline Graat Dyke of Zimbabwe (C) event & $\mathrm{B}(5)$ & 2575 & Main sulphide zone & Great Dyke & & Zimbabwe & 2009 & Reserves and measured, indicated, and inferred resources & $2,135,592,000$ & & & 1.792530963 & 1.433275106 & 0.150328009 & 0.30105269 & & 3.677186768 & D. Causey, written comm., 2009 \\
\hline North Allantic Magmatic Province & & 55.65 & Platinova Au-Pd Reef & Skactgaard & & Greenland & 2005 & Inferted resource & $1,520,000,000$ & & & 0.04 & 0.61 & & 0.21 & & 0.86 & Platina Resources, Ltd. (2010b) \\
\hline Stillwater (C) LIP event & $\mathrm{B}(4 \mathrm{i})$ & 2704 & A-B chromite, West Fork area & Stillwater Complex & & USA & 1979 & Resource & $3,600,000$ & & & 0.685 & 1.714 & & & & 2.399 & Zientek (1993) \\
\hline \multirow[t]{3}{*}{ Stillwater (C) LP event } & $\mathrm{B}(\mathrm{ii})$ & 2704 & J-M Reef & Stillwater Complex & & USA & 2010 & Reserves and mineralized material & 149,399.000 & & & 3.68067246 & 12.88235361 & & & & 16.56302607 & $\triangle$ Abott and others (2011) \\
\hline & & 3033 & Main Reef Package & Stella layered intrusion & & RSA & 2009 & Reserves and measurrod, indicated, and inferred resources & $133,302,579$ & & & 0.685426928 & 0.799251463 & & 0.042220011 & & 1.506898401 & D. Causey, written camm, 2009 \\
\hline & & & Weld Rangec- Parks Recf PGE & Weld Range & & Australia & 1998 & Inferred resource & 14,760,0000 & & & 0.6 & 0.5 & & & & 1.1 & Parks (1998) \\
\hline West Pilbara (C) event & $B(4 i)$ & 2935 & Main sulfide layer (Frerguson Recef) & Murni Munni & & Australia & 2002 & Measured, indicated, and infereded resources & $23,600,000$ & 0.09 & 0.15 & 1.1 & 1.5 & 0.1 & 0.2 & & 2.9 & Platina Resources, Ldd. (2010a) \\
\hline Fast Kimberley (C) events & B (4vid) & 1856 & Top and Middle Reefs & Panton Sill & & Ausralia & 2003 & Measured, indicated, and infereded resources & $14,300,000$ & 0.3 & 0.08 & 2.2 & 2.4 & & 0.3 & & 5.2 & Platirum Australia (2003) \\
\hline Northem Baltica-1(C) LIP events & $\mathrm{A}(\mathrm{lv})$ & 2440 & Siika-Kămä Reef & Narkaus Intrusion & & Finland & 2003 & Measured, indicated, and infereded resources & $43,100,000$ & 0.08 & 0.21 & 0.72 & 2.7 & & 0.11 & & 3.53 & Geological Survey of Finland (2010) \\
\hline Northem Baltica-1(C) LIP events & $A(\mathrm{lv})$ & 2440 & Sompüuârvi Reef & Penikat Intrusion & & Finland & & & $6,700,000$ & & & 3.08 & 5.36 & 0.38 & 0.1 & & 8.92 & Geological Survey of Finland (2010) \\
\hline \multirow[t]{2}{*}{ Norhern Baltica-1 (C) LIP events } & $\mathrm{A}(\mathrm{lv})$ & 2440 & Pasivivarara Reef & Penikat Intrnsion & & Finland & & & $5,000,000$ & & 0.28 & 4.04 & 2.58 & 0.08 & 0.61 & & 7.31 & Geological Survey of Finland (2010) \\
\hline & & & Pedra Branca & $\begin{array}{l}\text { Troia nitito fhe Cruzeta } \\
\text { Complex }\end{array}$ & & Brazil & 2009 & Inferred resource & 00.000 & 0.23 & 0.03 & & & & & 2.27 & 2.27 & Anglo Platinum (2) \\
\hline
\end{tabular}

Click here for larger view. 
Table 3. Tonnage and grade characteristics of contact-type copper-nickel platinum-group elements deposits. Values represent the total of resources and past production. Large igneous province (LIP) names and ratings from Ernst and Buchan (2001).

\begin{tabular}{|c|c|c|c|c|c|c|c|c|c|c|c|c|c|c|c|c|c|c|}
\hline $\begin{array}{ll}\text { Magnatic event } \\
\end{array}$ & LP Rating & $\begin{array}{l}\text { Approximate age } \\
\left(M_{\mathrm{a} a}\right)\end{array}$ & Deposit name & Property name & Intrusion1 & Intrusion2 & Country & Aggregrated & Area_sokm & 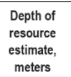 & Mine-tppe & Tons of ore & Ni, percent & 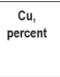 & $P t, g t$ & Pd, gtt & $\mathrm{Au}, \mathrm{gth}^{\mathrm{t}}$ & Reference \\
\hline Northem Battica-1 (C) LP events & $A(1)$ & 2440 & Almavara & Sulanklo project & Pertimo & Suhanko Itrtusion & Finland & оne & 0.8682 & 250 & op & $106,693,000$ & 0.09 & 0.23 & 0245 & 1.165 & 0.139 & Punitch and olters (2007) \\
\hline Bushveld $(C)$ LIP event & $A(1)$ & 2054 & Akanai & Akanai & Busiveld & 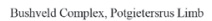 & RSA & one & 3.8351 & 2000 & ug & $269,70,0000$ & 021 & 0.12 & 1440 & 1.710 & 0.200 & Lomin Platinum 2007) \\
\hline Bushveld (C) LIP event & $A(\mathrm{ls})$ & 2054 & 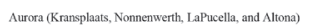 & Aurora Project & Buswela & 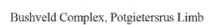 & RSA & ${ }_{\operatorname{many}}$ & 8.6364 & 200 & op & 13,430,000 & 0.05 & 0.08 & 0436 & 0.714 & 0.191 & Para Pallatium Limied $(2005,2007)$ \\
\hline Stillwater (C) LIP event & $B(4)$ & 2701 & Benbow & Bentow & Stillwater & Stillwater Conplex & USA & one & 0260013 & ${ }_{457}$ & op & 130,065264 & 022 & 0.22 & 0.007 & 0.011 & & Zientek (1993) \\
\hline Kewercanaran (C) LIP everat & $A(1 v)$ & 1099 & Birch Lake & Birch Lake & Duluth & South Kawishiswi Intrusion & USA & оне & 25445 & 840 & op & $195,504,000$ & 0.16 & 0.53 & 0255 & 0.552 & 0.123 & Reulldedec (2009) \\
\hline Stillwater (C) LIP event & $B(4)$ & 2701 & Cann deposit & AMAX Canp deposit & Stillwater & Sillwater Complex & USA & one & 0.0900111 & & op & $5,580.000$ & 0.42 & 0.23 & 0.018 & 0.1385 & & Zientek (1993) \\
\hline Norttcm Baltica-1 (C) LIP events & $A(1 v)$ & 2440 & Fedabero & Fedderovo project & Federovo & Fedorovo Intusion & Russia & one & 2.049 & & op & 166,210,000 & 0.09 & 0.15 & 0.311 & 0.933 & 0.084 & 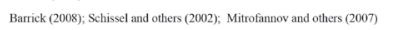 \\
\hline Kewerenaxan (C) LIP event & $A(v)$ & 1100 & Geordie Lake & Geordie Lakle & Coldsell & Coldwell Complex & Canada & оne & 0.3940 & 200 & ip & $29,800,000$ & 0.01 & 0.33 & 0.030 & 0.550 & 0.040 & PEE Mining Consullant. she. 2007) \\
\hline Busheld (C) LIP event & $A(1)$ & 2054 & Grass Valley, North and Soun Zones & Grass Valley Project & Busweld & Busiveld Complex, Poogigitersyns Limb & RSA & many & 0.8475 & 160 & op & $93,507.500$ & 0.11 & 0.03 & 0,510 & 0.590 & 0.030 & Pan Palladium Linited (2008s) \\
\hline Norttem Baltica-1 (C) LP events & $\Delta(1 v)$ & 2400 & Haukiaho & Hawkiaho & Koilismaa & Koilisman Layered lenousus Complex & Finland & one & 0.4070 & 150 & op & $27,000,000$ & 024 & 0.36 & 0209 & 0.549 & 0.216 & Hijina and others (2005) \\
\hline Northem Baltica-1(C) LP events & $A(1 v)$ & 2440 & Kontijiarvi & Sulanko project & Perimo & Kontijarvi Intrusion & Finland & one & 0.3955 & 200 & op & $42,110,000$ & 0.06 & 0.13 & 0.408 & 1.436 & 0.106 & Purich and oheres (2007) \\
\hline Keweranaxa (C) LP event & $A(1 v)$ & 1100 & Marathon & Maratton PGM.Cu Project & Coldurell & Coldwell Complex & Canada & one & 0.5924 & 350 & op & $70,200,000$ & 0.03 & 032 & 0250 & 0910 & 0 & 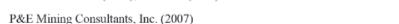 \\
\hline 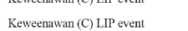 & $A(v)$ & 1099 & Maturi and Nokomis & Maturi and Nokomis & Dululh & South Kawishiswi Intrusion & USA & many & 3.648 & 900 & op, ug & 623.013 .000 & 021 & 0.62 & & 0.306 & 0070 & 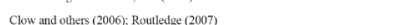 \\
\hline Kewewenaxan (C) LIP event & $A(v)$ & 1009 & Mesaha & Minnamax, Bablitit, AMAX arca & Duluth & Partridge River intrusion & 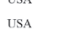 & one & 9.11100 & & op & $\begin{array}{lll}1,200,0,00,0,000 \\
-1000\end{array}$ & 0.09 & 0.43 & & & & 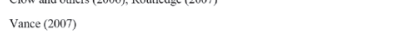 \\
\hline Bushreld (C) LIP event & $\mathrm{A}(\mathrm{s})$ & 2054 & Mokopanc & Mokoppanc & Busiveld & Busavold Complex, Pogezictersans Limb & RSA & one & 0.5778 & 320 & op & $39,70,000$ & 0.15 & 0.09 & 0.220 & 0.330 & & 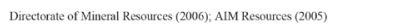 \\
\hline Stallwater (C) LIP event & $B(4)$ & 2701 & Moxat & Mouat & Stillwater & Stillwater Complex & USA & one & 0.4931 & 580 & op & 132,000,000 & 0.31 & 0.29 & 0.004 & 0.011 & & Zientek (1993) \\
\hline Northem Baltica- (C) L.P events & $A(1 v)$ & 2440 & M. Generalsksyayn & M. Generalstaya & Mt Geveralksaya & Mt. Genentlstaya & Russia & one & & & op & $53,33,500$ & 0.51 & 0.26 & 0.225 & 2.025 & 0.008 & Geological Survey of Finland (20099) \\
\hline Northem Baltica-1 (C) LIP events & $A(1)$ & 2440 & Nitrylampi & Nitrylampi & Portimo & Sumanko Intrusion & Finland & one & & 200 & op & 850,000 & 0.67 & 0.49 & 0270 & 0.080 & 0.030 & Lathinan (1987) \\
\hline 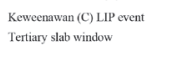 & $A(1)$ & ${ }_{40}^{1009}$ & $\begin{array}{l}\text { Nerther } \\
\text { Nunatak-Braty Giacier }\end{array}$ & $\begin{array}{l}\text { Dumka Read, UsS Dumka Road/rea } \\
\text { Numakak-Braty Giacier }\end{array}$ & $\begin{array}{l}\text { Dulum } \\
\text { La Perouse }\end{array}$ & $\begin{array}{l}\text { Partridge River intusion } \\
\text { La Perouse - Crillow }\end{array}$ & $\begin{array}{l}\text { USA } \\
\text { USA }\end{array}$ & $\begin{array}{c}\text { one } \\
\text { one }\end{array}$ & $\begin{array}{l}1.2200 \\
1.265264\end{array}$ & $\begin{array}{l}1090 \\
600\end{array}$ & op & $\begin{array}{l}492,30,0,000 \\
9,0,00,000\end{array}$ & $\begin{array}{l}0.08 \\
0.53\end{array}$ & $\begin{array}{l}0.27 \\
0.33\end{array}$ & $\begin{array}{l}0.065 \\
0.116\end{array}$ & $\begin{array}{l}0.237 \\
0.113\end{array}$ & 0.034 & 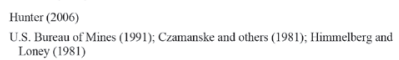 \\
\hline Stillwater (C) LIP event & B (4) & 2701 & Nye Basin & Nye Basin & Stillwater & Sailluater Complex & usA & one & 0.30076 & 457 & op & 783,688 & 0.22 & 0.254 & 0.003 & 0.009 & & Zicultck (1993) \\
\hline & & & 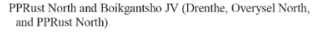 & PPRis North and Boikgantho $N V$ & Busiveld & Busweld Complex, Pogezieternas Limb & RSA & many & & & op & $1.667,914,500$ & 0.11 & 0.15 & 0.775 & 0.903 & 0.124 & Tulp and doters (2015): Arglo Phatinum (2006) \\
\hline Matachewan (C) LP evenn(s) & $A^{(3)}$ & 2440 & 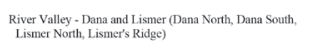 & 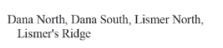 & River Valley & River Valley Mafici imnusion & Canada & ${ }_{\text {many }}$ & 0.6663 & 300 & ор & $28,18,000$ & 0.02 & 0.10 & 0332 & 0.968 & 0.060 & Prairic North West Capial Capr. (2000) \\
\hline Stillwater (C) LIP event & $B(4)$ & 2701 & Rocky Claim Group (Chrome Lake) & Rocky Claim Group & Stillwater & Stillwater Complex & USA & one & 0.122937 & 213 & op & $49,000,000$ & 0.28 & 0.26 & 0.005 & 0.011 & & Zientek (1993) \\
\hline Bushveld (C) L.LP event & $A(\mathrm{~s})$ & 2054 & Rooipor,, L and 13 zones & Rooipoort & Bussveld & Buswrveld Complex, Pogégictersas Limb & RSA & one & 3.9358 & 200 & op & $18,128,000$ & 0.19 & 0.11 & 0.470 & 0.736 & 0.085 & Vetreck and Lomber (2005) \\
\hline Norther Baltica-1 (C) LP eventls & $A(1 v)$ & 2440 & Rusamo & Rusame & Koilismaa & Kölisma Layered Igneous Complex & Finland & one & & 100 & op & $1,500,000$ & 024 & 0.39 & 0.266 & 0.384 & 0.150 & Lathinen (1983) \\
\hline Busheld (C) LIP event & $A(l s)$ & 2054 & Sandsloot & 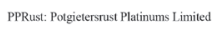 & Busivela & 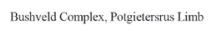 & $\mathrm{RSA}$ & опе & 1.0300 & 500 & op & $320,160,000$ & 0.09 & 0.17 & 1.163 & 1.348 & 0.208 & Anglo Platinum (2006) \\
\hline Keweenaxan (C) LIP event & $A(1 v)$ & 1099 & Seppentine & Serpentine (Bear Creak/AMAX) & Duluh & South Kawisisiswi Innnsion & USA & опе & 0.8343 & & op & $6,350,400$ & 0.30 & 0.88 & & & & Miller and others (2002) \\
\hline Busheld (C) LIP event & $A(1)$ & 2054 & Slucta's Ridge & Shcta's Ridge & Busiveld & Bustweld Complex, eastern linb & RSA & one & 5.0390 & 400 & op & $716,000,000$ & 0.19 & 0.07 & 0210 & 0.620 & 0.080 & Rilge Mining ple (2008) \\
\hline Kewerenaxan (C) L.JP everent & $A(v)$ & 10099 & Spruce Road & Spruce Road (INCO) & Duluh & South Kawsihiswi hntrusion & USA & one & 1.7138 & 530 & op & $405,100,000$ & 0.14 & 0.38 & & & & Roultedece and Cox 20007$)$ \\
\hline Norttlem Baltica-1 (C) LP events & $A(1 v)$ & 2440 & Sulankto & Suluanto & Portimo & Suhanko Itrtusion & Finland & one & & 100 & op & $1,000,000$ & 0.27 & 0.31 & 0200 & 0.900 & 0.030 & Gcological Survey of inilund (2009)) \\
\hline Northem Baltica-1 (C) LP events & $A(1 v)$ & 2440 & Vaaralumpi & Vararlalmpi & Pertimo & Suluarko hrtrusion & Finland & onc & & 150 & op & 6.050 .000 & 0.31 & 0.20 & 0.200 & 0.550 & 0.060 & 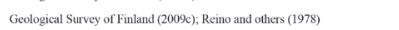 \\
\hline Bushveld (C) LIP event & $\Lambda(\mathrm{ls})$ & 2054 & War spings & War Springs & Busweld & Busisveld Complex, Pogizictersans Limb & RSA & one & 1.4739 & 500 & op & $46,95,5000$ & 0.13 & 0.10 & 0.250 & 0.780 & 0.070 & Platirum Group Metals (2008) \\
\hline naxan (C) LIP event & $A(1 v)$ & 1099 & Wetlegs & Weltegs (BBa & Duluth & ar intusion & USA & one & 1.32 & & op & 34, & 0.10 & 0.2 & & & & 102) \\
\hline Buskred (C) LIP event & $\Lambda(s)$ & 2054 & Zwartitentin Sounh & 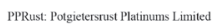 & Busweld & 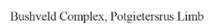 & RSA & one & 0.2597 & 300 & cp & 145,720,000 & 0.10 & 0.19 & 1.055 & 1.156 & 0.166 & Anglo Patianum (2006) \\
\hline
\end{tabular}

Click here for larger view. 
Table 4. Ages of intrusions that host reef-type platinum-group elements and contact-type Cu-Ni-PGE deposits.

[LIP (large igneous province) event names from Ersnt and Buchan (2001); La Perouse data by K-Ar and Ar-Ar; Penikat data by $\mathrm{Sm}-\mathrm{Nd}$; all others by U-Pb dating of zircon; PGE, platinum-group elements; Ma, million years]

\begin{tabular}{|c|c|c|c|c|}
\hline Intrusion & LIP event & Age (Ma) & Reference & Mineral deposits \\
\hline La Perouse & & $\begin{array}{l}19.3 \pm 0.7 \text { to } \\
41.1 \pm 2.2\end{array}$ & $\begin{array}{l}\text { Hudson and Plafker } \\
\text { (1981); Loney and } \\
\text { Himmelberg (1983) }\end{array}$ & $\begin{array}{l}\text { Contact-type } \\
\text { deposits }\end{array}$ \\
\hline Skaergaard Intrusion & $\begin{array}{l}\text { NAVP (North Atlantic } \\
\text { Volcanic Province) }\end{array}$ & $55.59 \pm 0.13$ & $\begin{array}{l}\text { Hamilton and Brooks } \\
\text { (2004) }\end{array}$ & Reef-type PGE \\
\hline $\begin{array}{l}\text { Duluth Complex (Partridge } \\
\text { River Intrusion) }\end{array}$ & Keweenawan & $1095.94 \pm 0.18$ & Hoaglund (2010) & $\begin{array}{l}\text { Contact-type } \\
\text { deposits }\end{array}$ \\
\hline Coldwell Complex & Keweenawan & $1108 \pm 1$ & $\begin{array}{l}\text { Heaman and Mackado } \\
\text { (1992) }\end{array}$ & $\begin{array}{l}\text { Contact-type } \\
\text { deposits }\end{array}$ \\
\hline Panton Sill & East Kimberley & $1856 \pm 2$ & Page and Hoatson (2000) & Reef-type PGE \\
\hline Bushveld Complex & Bushveld & $2054.4 \pm 1.3$ & $\begin{array}{l}\text { Scoates and Friedman } \\
(2008)\end{array}$ & $\begin{array}{l}\text { Reef-type PGE; } \\
\text { contact-type } \\
\text { deposits }\end{array}$ \\
\hline Penikat Intrusion & Northern Baltica-1 & $2410 \pm 64$ & Huhma and others (1990) & Reef-type PGE \\
\hline $\begin{array}{l}\text { Mount General'skaya } \\
\text { Intrusion }\end{array}$ & Northern Baltica-1 & $\begin{array}{l}2496 \pm 10 \\
2446 \pm 10\end{array}$ & $\begin{array}{l}\text { Bayanova and others } \\
\text { (2009) }\end{array}$ & $\begin{array}{l}\text { Contact-type } \\
\text { deposit }\end{array}$ \\
\hline Federova-Pana Intrusion & Northern Baltica-1 & $\begin{array}{l}25326 \pm 6 \\
2496 \pm 7\end{array}$ & Nitkina (2006) & $\begin{array}{l}\text { Reef-type PGE; } \\
\text { contact-type } \\
\text { deposits }\end{array}$ \\
\hline $\begin{array}{l}\text { Portimo Complex (Suhanko- } \\
\text { Konttijärvi and Narkaus } \\
\text { Intrusions) }\end{array}$ & Northern Baltica-1 & 2440 to 2435 & Iljina (1994) & $\begin{array}{l}\text { Reef-type PGE; } \\
\text { contact-type } \\
\text { deposits }\end{array}$ \\
\hline River Valley Intrusion & Matachewan & $2475+2-1$ & James and others (2002) & $\begin{array}{l}\text { Contact-type } \\
\text { deposits }\end{array}$ \\
\hline Great Dyke & $\begin{array}{l}\text { Great Dyke of } \\
\text { Zimbabwe }\end{array}$ & $2575.4 \pm 0.7$ & Oberthür and others (2002) & Reef-type PGE \\
\hline Stillwater Complex & Stillwater & $2704 \pm 4$ & Premo and others (1990) & $\begin{array}{l}\text { Reef-type PGE; } \\
\text { contact-type } \\
\text { deposits }\end{array}$ \\
\hline $\begin{array}{l}\text { Troia Unit of the Cruzeta } \\
\text { Complex }\end{array}$ & & 2.7 to $3.0 \mathrm{Ga}$ & Fetter (1999) & Reef-type PGE \\
\hline Munni Munni Intrusion & West Pilbara & $2935 \pm 16$ & Arndt and others (1991) & Reef-type PGE \\
\hline Stella Intrusion & & $3033.5 \pm 0.3$ & Maier and others (2003) & Reef-type PGE \\
\hline
\end{tabular}


Table 5. Examples of cut-off criteria used to define contact-type Cu-Ni-platinum-group elements deposits.

[PGE, platinum-group elements; GMV is gross metal value; NMV is net metal value; NSR is net smelter return]

\begin{tabular}{|l|l|l|}
\hline \multicolumn{1}{|c|}{ Intrusion } & \multicolumn{1}{c|}{ Deposits } & \multicolumn{1}{c|}{ Cut-off criteria } \\
\hline Portimo Complex, Finland & Suhanko and Kontijärvi & $0.8 \mathrm{~g} / \mathrm{t} \mathrm{Pt}+\mathrm{Pd}+\mathrm{Au}$ \\
\hline Koilismaa Intrusion, Finland & Lavotta and Niittylampi & $0.7 \%(\mathrm{Cu}+2 \mathrm{xNi})$ \\
\hline River Valley Intrusion, Ontario & Dana, Lismer, Varley & $0.7 \mathrm{~g} / \mathrm{t} \mathrm{Pt}+\mathrm{Pd}$ \\
\hline Bushveld, Platreef, South Africa & War Springs & $\mathrm{Pt}+\mathrm{Pd}+\mathrm{Rh}=300 \mathrm{cmg} / \mathrm{t}$ \\
& Boikgantsho JV & $\mathrm{US} \$ 10 \mathrm{GMV} / \mathrm{t}$ \\
& Rooipoort & $0.5 \mathrm{~g} / \mathrm{t} \mathrm{PGE}+\mathrm{Au}$ \\
\hline Duluth Complex, Minnesota & Spruce Road & $0.26 \%$ copper equivalent \\
& Serpentine & $0.6 \% \mathrm{Cu}$ \\
& Northmet & US $\$ 7.42 \mathrm{NMV} / \mathrm{t}$ \\
& Maturi and Nokomis & US $\$ 25 \mathrm{NSR}$ and $0.8 \% \mathrm{Cu}$ \\
\hline Stillwater Complex, Montana & Mouat & $0.1 \% \mathrm{Ni}$ and $0.1 \% \mathrm{Cu}$ \\
\hline
\end{tabular}

Table 6. Summary statistics of contact-type Cu-Ni-platinum-group elements deposits reported in table 2.

[PGE, platinum-group elements; g/t; grams per ton]

\begin{tabular}{lrrrcrc}
\hline & Tons of ore & Ni, percent & Cu, percent & Pt, g/t & Pd, g/t & Au, g/t \\
\hline Minimum & 850,000 & 0.01 & 0.03 & 0.0032 & 0.0087 & 0.0080 \\
Quantile-25th & $22,564,000$ & 0.09 & 0.13 & 0.1234 & 0.2832 & 0.0529 \\
Median & $70,200,000$ & 0.16 & 0.25 & 0.2450 & 0.6200 & 0.0846 \\
Quantile-75th & $232,602,000$ & 0.26 & 0.33 & 0.3746 & 0.9346 & 0.1539 \\
Maximum & $1,667,914,500$ & 0.67 & 0.88 & 1.4400 & 2.0250 & 0.2160 \\
Mean & $206,497,877$ & 0.19 & 0.26 & 0.3212 & 0.6825 & 0.1019 \\
Number of deposits & 37 & 37 & 37 & 33 & 33 & 26 \\
\hline
\end{tabular}

